\title{
Geochemical Study of Groundwater at Sandia National Laboratories/New Mexico and Kirtland Air Force Base
}

October 1995
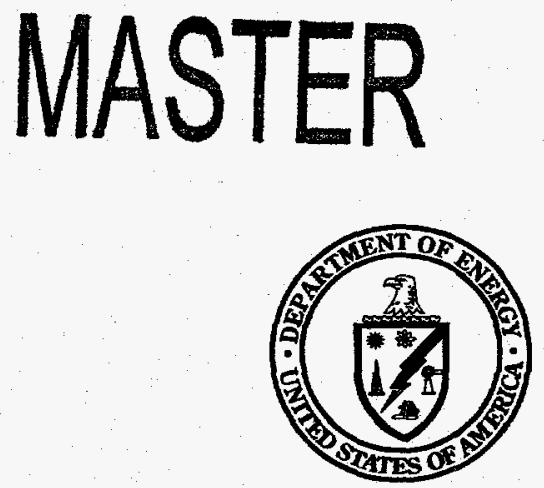

U.S. Department of Energy Grand Junction Projects Office

FMSTARITION OF THS DOCUMENT IS UNLIMITED 


\section{Geochemical Study of Groundwater}

\section{at Sandia National Laboratories/New Mexico and

\author{
Kirtland Air Force Base
}

October 1995

\section{DISCLAIMER}

This report was prepared as an account of work sponsored by an agency of the United States Government. Neither the United States Government nor any agency thereof, nor any of their employees, makes any warranty, express or implied, or assumes any legal liability or responsibility for the accuracy, completeness, or usefulness of any information, apparatus, product, or process disclosed, or represents that its use would not infringe privately owned rights. Reference herein to any specific commercial product, process, or service by trade name, trademark, manufacturer, or otherwise does not necessarily constitute or imply its endorsement, recommendation, or favoring by the United States Government or any agency thereof. The views and opinions of authors expressed herein do not necessarily state or reflect those of the United States Government or any agency thereof.

\section{Prepared by Rust Geotech}

U.S. Department of Energy

Albuquerque Operations Office

Grand Junction Projects Office

Grand Junction, Colorado

Under DOE contract No. DE-AC04-94AL96907 


\section{DISCLAIMER}

Portions of this document may be illegible in electronic image products. Images are produced from the best available original document. 



\section{Contents}

Page

Executive Summary $\ldots \ldots \ldots \ldots \ldots \ldots \ldots \ldots \ldots \ldots \ldots \ldots \ldots$ vii

$1.0 \quad$ Introduction $\ldots \ldots \ldots \ldots \ldots \ldots \ldots \ldots \ldots \ldots \ldots \ldots \ldots \ldots \ldots \ldots \ldots$

2.0 Geochemical Data Used in This Study ................. 2-1

2.1 Selection of the Most Representative Data from

the 12 Sampling Periods $\ldots \ldots \ldots \ldots \ldots \ldots \ldots \ldots \ldots \ldots, 2-1$

2.2 Mineralogical Data $\ldots \ldots \ldots \ldots \ldots \ldots \ldots \ldots \ldots \ldots \ldots \ldots . \ldots \ldots$

3.0 Overview of Modeling Methods $\ldots \ldots \ldots \ldots \ldots \ldots \ldots \ldots \ldots \ldots \ldots \ldots, 1$

3.1 History of Modeling Methods $\ldots \ldots \ldots \ldots \ldots \ldots \ldots \ldots \ldots \ldots, 2$

3.2 Mathematical Treatment $\ldots \ldots \ldots \ldots \ldots \ldots \ldots \ldots \ldots \ldots \ldots$ 3-3

3.3 Model Assumption and Uncertainties ................. 3-5

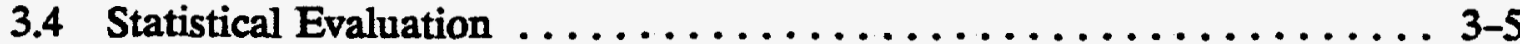

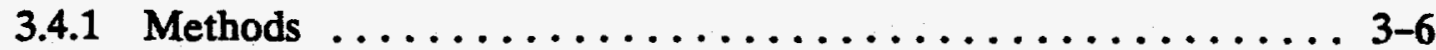

3.4.2 Results ......................... 3-6

4.0 Description of the Sandia/KAFB Site $\ldots \ldots \ldots \ldots \ldots \ldots \ldots \ldots \ldots$ 4-1

4.1 Geology . . . . . . . . . . . . . . . . . . . . . . . 4 4-1

4.2 Surface-Water Hydrology $\ldots \ldots \ldots \ldots \ldots \ldots \ldots \ldots \ldots \ldots \ldots .4$.

4.3 Groundwater Hydrology $\ldots \ldots \ldots \ldots \ldots \ldots \ldots \ldots \ldots \ldots . \ldots \ldots$ 4-6

4.4 Groundwater Major-Ion Geochemistry ................. 4-6

4.5 Stable Isotopes of Oxygen and Hydrogen . . . . . . . . . . . 4-14

4.6 Mineralogy $\ldots \ldots \ldots \ldots \ldots \ldots \ldots \ldots \ldots \ldots \ldots \ldots \ldots, 4-24$

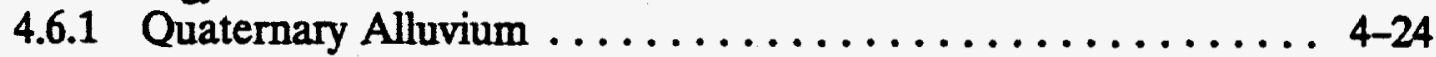

4.6 .2 Santa Fe Group ...................... 4-24

4.6.3 Lower Tertiary ....................... 4-29

4.6 .4 Yeso Formation ...................... 4-29

4.6.5 Abo Formation ........................ 4-29

4.6.6 Madera Limestone ... . . . . . . . . . . . . . . . . . 4-29

4.6.7 Precambrian Basement ..................... 4-29

5.0 Sandia/KAFB Groundwater Origins and Flow Paths ........... 5-1

5.1 Groundwater Movement Along Faults; Coyote Springs and EOD Hill .. 5-1

5.2 Midbasin Santa Fe Group Groundwater (CWL-BW2 and MWL-BW1) 5-6

5.3 Groundwater at South Fence Road Wells ............... 5-8

5.3.1 Santa Fe Group Groundwater Chemistry ............. 5-8

5.3.2 Lower Tertiary Groundwater in the Footwall ........... 5-10

5.4 Groundwater in the Tijeras Arroyo Area..$\ldots \ldots \ldots \ldots \ldots \ldots .54$

6.0 Conclusions and Recommendations $\ldots \ldots \ldots \ldots \ldots \ldots \ldots \ldots \ldots$ 6-1 
Contents (Continued)

Appendix A Appendix B Appendix C

Appendix D

Appendix E
Geochemical Database (sand.dat) Used in this Study . . . . . . . A-1 Histograms . . . . . . . . . . . . . . . . . . . B-1 Chemical Spot Plots for the Most Representative Data for All Wells and Springs C-1 Chemical Spot Plots for the Most Representative Data for Wells Screened in the Santa Fe Group .......... D-1 Summary of Mineralogy as Compiled from Well Logs and Thin Section Descriptions E-1

Tables

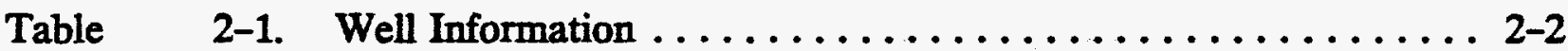

2-2. Rejected Data ....................... 2-3

2-3. Thermodynamic Data ................... 2-5

2-4. Parameters Calculated with PHREEQE ............. 2-6

2-5. Most Representative Data Used in This Investigation ...... 2-7

3-1. Results of T-Tests ..................... 3-7

4-1. Oxygen and Hydrogen Isotopic Results for Groundwater Collected in 1994 . . . . . . . . . . . . . . . . . . . . . . . . . . . 4-21

4-2. Oxygen and Hydrogen Isotopic Results for Surface Water Collected in 1994 . . . . . . . . . . . . . . . . . . . . . . . 4 4-22

5-1. Mass Balance Model for Coyote Springs From EOD Hill ... . . 5-2

5-2. Comparison of EOD Hill and CWL-BW2 Groundwater Chemistries ......................... 5-7

5-3. NETPATH Models: Mixing of EOD Hill Groundwater with Dilute Water to Produce CWL-BW2 Groundwater . . . . . . 5-7

5-4. NETPATH Models: Mixing of EOD Hill or CWL-BW2 Groundwater with Pure Water to Produce MWL-BW1 Groundwater ............................ 5-8

5-5. Dilution Factors for Major Ions to Produce SFR-3P from EOD Hill Groundwater . . . . . . . . . . . . . . . . 5-9

5-6. NETPATH Results of Mixing Groundwater from EOD Hill, SFR-3T, and Pure Water to Produce SFR-3P Groundwater ... . 5-9

5-7. Composition of SFR-3T Before and After Computed Reactions Compared to SFR-4T . . . . . .......... 5-10

5-8. NETPATH Model to Produce SFR-4T from SFR-3T Groundwater ......................... 5-11

5-9. NETPATH Calculated Chemical Interactions to Produce Golf Course South Groundwater from Pure Water . . . . . . . . 5-16 
Figures

Page

Figure 4-1. Stratigraphic Column for the Sandia/KAFB Area ......... 4-2

4-2. Geologic Map of the Sandia/KAFB Site and Sampling Locations . ........................ 4-3

4-3. Potential Surface Map, July $1993 \ldots \ldots \ldots \ldots \ldots \ldots \ldots$. . . . . . .

4-4. Piper Diagram of the MRD from All Wells and Springs Used in This Study . . . . . . . . . . . . . . . . . . 4-7

4-5. Spot Plot for All MRD Wells for $\mathrm{Cl}(\mathrm{mg} / \mathrm{L}) \ldots \ldots \ldots \ldots .44$

4-6. Spot Plot of MRD Wells Screened in the Santa Fe Group for $\mathrm{Cl}(\mathrm{mg} / \mathrm{L}) \ldots \ldots \ldots \ldots \ldots \ldots \ldots \ldots \ldots \ldots$ 4 11

4-7. Stiff Diagrams for EOD Hill and Coyote Spring (MRD) ... 4-13

4-8. Spot Plot of MRD Wells Screened in the Santa Fe Group for $\mathrm{SO}_{4}(\mathrm{mg} / \mathrm{L}) \ldots \ldots \ldots \ldots \ldots \ldots \ldots \ldots \ldots \ldots$ 4-15

4-9. Stiff Diagrams for the South Fence Road Wells (MRD) . . . . . 4-17

4-10. Spot Plot of All MRD Wells for NPN (mg/L) ......... 4-19

4-11. $\delta \mathrm{D}-\delta^{18} \mathrm{O}$ Plot of Water Samples from Sandia/KAFB ...... 4-23

4-12. Spot Plot of All MRD Wells for $\delta D \ldots \ldots \ldots \ldots \ldots \ldots \ldots$ 4-25

4-13. Spot Plot of MRD Wells Screened in the Santa Fe Group for $\delta D \ldots \ldots \ldots \ldots \ldots \ldots \ldots \ldots \ldots \ldots \ldots$ 4 $4 \ldots \ldots \ldots$

5-1. Stiff Diagrams Showing Reaction Paths as $\mathrm{CO}_{2}$ Exsolves from EOD Hill Water and Comparison to Coyote Springs at its Measured $\mathrm{pH}(6.15)$ and at $\mathrm{pH} 6.50 \ldots \ldots \ldots \ldots . . .65$

5-2. Mineral Saturation Indices and $\mathrm{CO}_{2}$ Partial Pressures During Exsolution of $\mathrm{CO}_{2}$ from EOD Hill Water ....... 5-4

5-3. Stiff Diagrams Showing the Chemical Evolution of SFR-3T Groundwater as $1.8,5.5$, and $11.0 \mathrm{mmol}$ of a Reaction are Added, Compared to SFR-4T ........ 5-12

5-4. Saturation Indices for Common Minerals During Reaction of SFR-3T . . . . . . . . . . . . . . . . 5-13

5-5. Schematic Diagram Showing Origin of SFR-4T Water from SFR-3T Water . . . . . . . . . . . 5 .15 


\section{Executive Summary}

Sandia National Laboratories/New Mexico (Sandia/NM) requested that the U.S. Department of Energy (DOE) Grand Junction Projects Office (GJPO), through its prime contractor, Rust Geotech, provide interpretation of groundwater geochemical data at Sandia/Kirtland Air Force Base (KAFB).

Existing analytical data were used to prepare a database with relevant chemical analyses for groundwater samples collected at the two sites. A subset of the database was selected that contains one set of chemical analyses for each sampling location (well or spring). These data were selected primarily on the basis of charge balance. Piper diagrams, Stiff diagrams, histograms, and spatial plots were used to display and analyze these geochemical data. Geochemical modeling using NETPATH and PHREEQE was used to help interpret observed trends.

Chemical similarities between groundwaters at Coyote Springs and EOD Hill suggest a common origin. Both groundwaters are elevated in ionic strength, $\mathrm{Cl}, \mathrm{TIC}, \mathrm{Na}, \mathrm{Ca}, \mathrm{K}$, and $\mathrm{Mg}$. A reaction-path model driven by $\mathrm{CO}_{2}$ loss provides a thermodynamically valid explanation for the evolution of these fault-related groundwaters. Stable isotopes of $\mathrm{D} / \mathrm{H}$ and ${ }^{18} \mathrm{O} /{ }^{16} \mathrm{O}$ support this reaction-path model.

Groundwater in the Santa Fe Group in the basin away from the boundary faults is dominated by a dilute component. Only minor chemical interactions between pure water and mineral phases are required to produce this dilute water. A more saline fluid upwells along the basin-boundary faults and mixes with the dilute groundwater.

Based on geochemical modeling, the chemical composition of the Santa Fe Group groundwater in the South Fence Road wells can be explained by mixing of dilute groundwater with saline groundwater upwelling along basin-boundary faults.

Approximately 62 percent of the dilute Santa Fe Group water must mix with 36 percent of a saline water similar in chemical composition to EOD Hill. An additional 2 percent of $\mathrm{SO}_{4}$-rich groundwater such as that present in SFR-3T is needed to balance the $\mathrm{SO}_{4}$.

The chemistry of the groundwater in the footwall (Lower Tertiary unit) of the fault along South Fence Road is explained by interaction with gypsum and Na-rich exchangeable clays. Groundwater in the vicinity of the SFR-3T well is in contact with gypsum, as indicated by the near-zero saturation index. This water, which is high in $\mathrm{Ca}$ and $\mathrm{SO}_{4}$, flows away from gypsiferous beds in the Yeso Formation and in the fault and contacts $\mathrm{Na}$-rich clays. $\mathrm{Ca}$ is exchanged for $\mathrm{Na}$ to produce the high-Na and high-SO $\mathrm{S}_{4}$ groundwater sampled in the SFR-4T well. A small component $(<2 \%)$ of this high-SO ${ }_{4}$ water mixes with the groundwater in the Santa $\mathrm{Fe}$ Group to produce slightly elevated $\mathrm{SO}_{4}$ concentrations near the faults.

A nitrate-plus-nitrite anomaly beneath the Tijeras Golf Course indicates vertical infiltration to greater than 400 feet. This local phenomena is due to the high infiltration 
of irrigation water containing nitrogen-based fertilizer. Mass-balance modeling shows that relatively pure infiltration water reacting with small amounts of calcite, gypsum, halite, and clays could produce this groundwater.

Although the modeling study is useful in characterizing and understanding the nature of chemical reactions occurring at the site, definitive conclusions about flow paths are illusive. The scarcity of mineralogical information restricts our ability to place constraints on the models. Collection of the large amount of subsurface data needed to model flow paths uniquely is impractical. It is recommended that more cost-effective information on flow paths would be generated by completing additional wells and by using environmental tracers such as ${ }^{3} \mathrm{H},{ }^{36} \mathrm{Cl}$, and ${ }^{14} \mathrm{C}$. 


\subsection{Introduction}

The U.S. Department of Energy (DOE) Grand Junction Projects Office (GJPO) and its contractor, Rust Geotech, support the Kirtland Area Office by assisting Sandia National Laboratories/New Mexico (Sandia/NM) with remedial action, remedial design, and technical support of its Environmental Restoration Program. To aid in determining groundwater origins and flow paths, the GJPO was tasked to provide interpretation of groundwater geochemical data.

The purpose of this investigation was to describe and analyze the groundwater geochemistry of the Sandia/NM Kirtland Air Force Base (KAFB). Interpretations of groundwater origins are made by using these data and the results of "mass balance" and "reaction path" modeling. Additional maps and plots were compiled. to more fully comprehend the geochemical distributions. A more complete set of these data representations are provided in the appendices. Previous interpretations of groundwaterflow paths that were based on well-head, geologic, and geochemical data are presented in various reports (Sandia/NM 1993, 1994, 1995) and were used as the basis for developing the models presented in this investigation.

A thorough understanding of groundwater flow directions and recharge areas is needed to make reliable predictions of the direction and extent of contaminant transport.

Geochemical modeling is a tool that aids in this understanding. An understanding of the chemical reactions that are occurring in the aquifer is also needed to make reliable predictions of the chemical retardation of the contaminants (retardation assessment was not part of this study). Geochemical modeling of field sites seldom produces a unique solution to the question of groundwater origin. Geochemical simulations can, however, be used to constrain conceptual groundwater flow models.

The main objectives of this study were (1) to present key groundwater chemistry from the Sandia/KAFB Site-Wide Hydrogeologic Characterization Project in a form that can be readily retrieved and used in interpretive studies and (2) to test the validity of various interpretations of groundwater flow paths and the location of recharge areas by using geochemical spatial relationships and reaction path methodologies. These objectives were met by preparing a set of graphical data representations, including spatial chemical plots, histograms, Piper diagrams, and Stiff diagrams. These data representations were then used to develop conceptual groundwater chemistry models that were tested against mass balance and thermodynamic constraints. 


\subsection{Geochemical Data Used in This Study}

Groundwater chemistry data used for this study include data from the Sandia/ER Project and the Sandia/NM Groundwater Protection Program. These sites were sampled regularly by the ER Project and the Groundwater Surveillance Task of the Groundwater Protection Program. Well data are provided in Table 2-1. Other groundwater data are available for the site, but these data are typically analyses of water samples from wells concentrated in specific waste-site areas that have not been routinely sampled for the purpose of defining major-ion chemistry. Analyses used in this study include major cations $(\mathrm{Ca}, \mathrm{Na}, \mathrm{K}, \mathrm{Mg})$; major anions $\left(\mathrm{SO}_{4}, \mathrm{Cl}\right)$, field alkalinity (used to compute bicarbonate $\left.\left[\mathrm{HCO}_{3}\right]\right)$ and $\mathrm{pH}$, nitrate $\left[\mathrm{NO}_{3}\right]$ or nitrate plus nitrite (NPN); and natural tracers; bromide $(\mathrm{Br})$; fluoride $(\mathrm{F})$.

Data from the 1992 (two samplings), 1993 (four samplings), and 1994 (three samplings) field seasons were used in this study. Almost all the wells numbered 1 through 13 and 18 and 19 (Table 2-1) and all the springs were sampled during these three sampling periods. Wells SFR-1D, SFR-2S, SFR-3P, and SFR-3T were not sampled in 1992. Data for wells 20 through 24 were available only for the 1995 sampling season (data provided by F. Lauffer). Data for wells 1 through 19 and the springs are in Sandia/NM (1993, 1994a, 1995).

\subsection{Selection of the Most Representative Data from the 12 Sampling Periods}

Because interpretation of groundwater origins involves determining the spatial variation of groundwater chemistry, the selection of a single set of chemical parameter values were necessary to represent each sampling location. Groundwater data from the 12 sampling periods were examined to determine if any chemical parameters varied systematically over time. No systematic variations were apparent. A set of data comprising a single set of chemical values was selected for each sampling location. This data compilation is called the most representative data (MRD). These MRD were selected from the best available data as determined by charge balance calculations.

Sampling data that lacked values for $\mathrm{Ca}, \mathrm{Na}, \mathrm{K}, \mathrm{Mg}, \mathrm{SO}_{4}, \mathrm{Cl}, \mathrm{pH}$, or alkalinity were rejected for use in the MRD. Because dissolved carbon dioxide $\left(\mathrm{CO}_{2}\right)$ will exchange with the atmosphere, $\mathrm{pH}$ and alkalinity measurements are reliable indicators of subsurface conditions only if these measurements are made immediately after sampling. Therefore, samplings that did not include field measurements of $\mathrm{pH}$ and alkalinity were not used in the MRD. If any analyses of $\mathrm{Ca}, \mathrm{Na}, \mathrm{K}, \mathrm{Mg}, \mathrm{SO}_{4}, \mathrm{Cl}, \mathrm{pH}$, or alkalinity were "suspect," data from that sampling period were not used in the MRD. "Suspect data" are those data that have a significant deviation from typical values, as indicated by comparison with data from other sampling periods. "Suspect" data were identified based solely on the judgement that these analytical values are unlikely to be real; likely they are due to reporting errors or equipment malfunctions. No data were eliminated based on statistical outlier analysis. Because wells MRN-2 and PL-1 had high turbidity and 
Table 2-1. Well Information"

\begin{tabular}{|c|c|c|c|c|c|}
\hline (6. & Woll Nane & Wal bepth $($ red) & $\begin{array}{l}\text { Wopth } \\
\text { \%onats } \\
\text { (to-t) }\end{array}$ & $\begin{array}{l}\text { Sereened } \\
\text { Tnternd } \\
\text { (feet) }\end{array}$ & Somplod/Ceologic \\
\hline 1 & Burn Site Well & 350 & 68 & $231-341$ & $p \epsilon_{*}$ \\
\hline 2 & CWL-BW2 & 998 & $499^{\circ}$ & $490-980$ & Tsf \\
\hline 3 & EOD Hill & 212 & $144^{\circ}$ & $204-212$ & $\mathbf{P m}$ \\
\hline 4 & Golf Course South & 495 & $315^{\circ}$ & $437-457$ & Tsf \\
\hline 5 & Greystone & 57 & $53^{\circ}$ & $44-54$ & Qal \\
\hline 6 & KAFB-10 & 1050 & $496^{\circ}$ & $495-814$ & Tsf \\
\hline 7 & LF/DM-01 & 480 & 457 & $415-465$ & Tsf \\
\hline 8 & LF/DM-02 & 450 & $404^{\circ}$ & $378-428$ & Tsf \\
\hline 9 & MVMW-J & 225 & $216^{\circ}$ & $200-220$ & Tsf \\
\hline 10 & MVMW-K & 300 & $290^{\circ}$ & $275-295$ & Tsf \\
\hline 11 & MWL-BW1 & 519 & $465^{c}$ & $452-472$ & Tsf \\
\hline 12 & NW-TA3 & 461 & $449^{\circ}$ & $435-455$ & Tsf \\
\hline 13 & Schoolhouse & 107 & $95^{\circ}$ & $83-103$ & Qal and $p \in$ \\
\hline 14 & SFR-1D & 510 & $92^{d}$ & $348-368$ & Tsf \\
\hline 15 & SFR-2S & 365 & $101^{d}$ & $97-117$ & Tsf \\
\hline 16 & SFR-3P & 914 & $164^{e}$ & 175-195 & Tsf \\
\hline 17 & SFR-3T & 1154 & $92^{d}$ & $713-733$ & $\mathrm{~T} \ell$ \\
\hline 18 & SW-TA3 & 467 & $426^{\circ}$ & $407-427$ & Tsf \\
\hline 19 & Tijeras East & 571 & $478^{\circ}$ & $465-527$ & Tsf \\
\hline 20 & SFR-4T & 377 & $294^{4}$ & $340-360$ & $T \ell$ \\
\hline 21 & PL-3 & 480 & $452^{\circ}$ & $445-465$ & Tsf \\
\hline 22 & TRN-1 & 510 & $82^{d}$ & $320-340$ & $\mathbf{P a}$ \\
\hline 23 & MRN-2 & 455 & $414^{d}$ & $410-440$ & Tsf \\
\hline 24 & TJA-2 & 310 & $274^{d}$ & $275-295$ & Tsf \\
\hline
\end{tabular}

- Data provided by W. Foutz (Sandia/NM).

b Geologic units: $p \in=$ Precambrian basement; $s$ = schist; and $g=$ granite.

Formations: $\mathrm{Oal}=$ Quaternary alluvium; $T s f=$ Tertiary Santa Fe Group; $T \ell=$ Lower

Tertiary (pre-Tsf); Pa = Permian Abo Formation; and Pm = Madera Formation (limestone).

c Depth to water measured December 1994.

d Depth to water from well completion records.

- No depth to water reported for PL-3, this value is from PL-2 drilled 5 feet away. 
were located close to other wells, they were not included in this study. Although Hubbel Springs has somewhat erratic $\mathrm{pH}$ values and KAFB-10 potentially has problematic analyses for alkalinity, $\mathrm{Cl}$, and $\mathrm{pH}$, these sampling sites were included for comparison purposes.

The analyses rejected because of lack of data or "suspect data" are listed in Table 2-2.

Table 2-2. Rejected Data

\begin{tabular}{|c|c|c|}
\hline Sampling Location & Sampling Date & Reason for Rejection \\
\hline Burn Site & July 1993 & Low SO \\
\hline Burn Site & April 1993 & Low $\mathrm{Mg}$ \\
\hline Coyote Springs & March 1994 & No field alkalinity \\
\hline Coyote Springs & September 1993 & Low Mg \\
\hline Coyote Springs & December 1993 & Low $\mathrm{Na}$ \\
\hline Coyote Springs & July 1993 & Low $\mathrm{SO}_{4}$ \\
\hline Coyote Springs & July 1992 & Low alkalinity \\
\hline CWL-BW2 & April 1993 & Low Cl \\
\hline EOD Hill Well & July 1992 & Low $\mathrm{Ca}$ \\
\hline Golf Course South & June 1994 & No field alkalinity \\
\hline Golf Course South & July 1993 & No field alkalinity \\
\hline Golf Course South & April 1993 & High $\mathrm{K}$ \\
\hline Golf Course South & January 1992 & Low pH, Low Ca \\
\hline Greystone & March 1994 & Low $\mathrm{SO}_{4}$ \\
\hline Greystone & July 1993 & No field alkalinity \\
\hline Hubbell Spring & September 1994 & High field alkalinity \\
\hline KAFB-10 & March 1994 & No field alkalinity \\
\hline KAFB-10 & April 1993 & No field alkalinity \\
\hline LF/DM-1 & July 1993 & Low field alkalinity \\
\hline LF/DM-2 & July 1993 & High field alkalinity \\
\hline LF/DM-2 & April 1993 & High Ca \\
\hline MVMW-J & July 1993 & Low pH \\
\hline MVMW-K & March 1994 & No field alkalinity \\
\hline MVMW-K & January 1992 & High Cl \\
\hline MWL-BW1 & March 1994 & No field alkalinity \\
\hline NW-TA3 & July 1993 & No field alkalinity \\
\hline NW-TA3 & April 1993 & High Cl \\
\hline Schoolhouse & March 1994 & Low $\mathrm{Cl}$ \\
\hline
\end{tabular}


Table 2-2 (continued). Rejected Data

\begin{tabular}{|c|c|c|}
\hline Samplins Location & Sampling Date & Rensor for Rejection \\
\hline Schoolhouse & July 1992 & Low Cl \\
\hline Sol se Mete Spring & March 1994 & No field alkalinity \\
\hline Sol se Mete Spring & December 1993 & No field alkalinity \\
\hline Sol se Mete Spring & July 1993 & No field $\mathrm{pH}$ \\
\hline Sol se Mete Spring & April 1993 & Low field pH \\
\hline SFR-1D & July 1993 & No field alkalinity \\
\hline SFR-2S & July 1993 & No field alkalinity \\
\hline SW-TA3 Well & July 1993 & Low pH \\
\hline SW-TA3 Well & April 1993 & High pH \\
\hline Tijeras East & August 1992 & Low $\mathrm{SO}_{4}$ \\
\hline MRN-1 & April 1995 & High turbidity \\
\hline PL-2 & April 1995 & High turbidity \\
\hline
\end{tabular}

Major cation, major anion, and $\mathrm{pH}$ data were used to compute the equilibrium ion distributions and mineral saturation indices for each groundwater sample with the program PHREEQE (Parkhurst et al. 1980). Table 2-3 lists the thermodynamic data used in this investigation.

Groundwater temperatures ranged from 7 to $24{ }^{\circ} \mathrm{C}$ but were generally between 15 and $20^{\circ} \mathrm{C}$. PHREEQE computations were performed at $25^{\circ} \mathrm{C}$, the standard temperature at which free energy data are reported. The small size of the temperature corrections would not affect the interpretations in this study.

The cation/anion ratios calculated by PHREEQE were used to select the MRD. Table 2-4 presents the cation/anion ratios calculated by PHREEQE for the data sets that remained after eliminating those that are based on lack of data or "suspect data."

Cation/anion ratios will approximate 1.0 if all chemical analyses are accurate and all significant components are included. Deviations from 1.0 indicate that these conditions are not met. Therefore, the MRD consists of the data set from each location that has a cation/anion ratio closest to 1.0. The MRD are listed in Table 2-5. The database containing the complete set of data is a text file named sand.dat and is included as Appendix A. 
Table 2-3. Thermodynamic Data

\begin{tabular}{|c|c|}
\hline 1.9 .19 .7$, Dissolved Species. & Log $(25 \% 9)$ \\
\hline $\mathrm{H}_{2} \mathrm{O}=\mathrm{OH}+\mathrm{H}^{\top}$ & -14.00 \\
\hline $\mathrm{CO}_{3}^{2}+\mathrm{H}^{2}=\mathrm{HCO}_{3}$ & 10.33 \\
\hline $\mathrm{CO}_{3}^{2}+2 \mathrm{H}^{+}=\mathrm{CO}_{2}^{\circ}+\mathrm{H}_{2} \mathrm{O}$ & 16.681 \\
\hline $\mathrm{SO}_{4}^{2-}+\mathrm{H}^{+}=\mathrm{HSO}_{4}^{2}$ & 1.987 \\
\hline $\mathrm{Ca}^{2+}+\mathrm{H}_{2} \mathrm{O}=\mathrm{CaOH}^{+}+\mathrm{H}^{+}$ & -12.598 \\
\hline $\mathrm{Ca}^{2+}+\mathrm{CO}_{3}^{2}=\mathrm{CaCO}_{3}{ }^{\circ}$ & 3.153 \\
\hline $\mathrm{Ca}^{2+}+\mathrm{CO}_{3}^{2+}+\mathrm{H}=\mathrm{CaHCO}_{3}$ & 11.345 \\
\hline $\mathrm{Ca}^{2+}+\mathrm{SO}_{4}^{2}=\mathrm{CaSO}_{4}^{\circ}$ & 2.309 \\
\hline $\mathrm{Mg}^{2}+\mathrm{H}_{2} \mathrm{O}=\mathrm{MgOH}^{+}+\mathrm{H}^{\mp}$ & -11.794 \\
\hline $\mathrm{Mg}^{2+}+\mathrm{CO}_{3}^{2+}=\mathrm{MgCO}_{4}^{\circ}$ & 2.980 \\
\hline $\mathrm{Mg}^{2+}+\mathrm{CO}_{3}^{2}+\mathrm{H}^{+}=\mathrm{MgHCO}_{3}^{+}$ & 11.396 \\
\hline $\mathrm{Mg}^{2+}+\mathrm{SO}_{4}^{2}=\mathrm{MgSO}_{4}^{\circ}$ & 2.250 \\
\hline $\mathrm{Na}^{+}+\mathrm{CO}_{3}^{2-}=\mathrm{NaCO}_{3}^{-}$ & 1.268 \\
\hline $\mathrm{Na}^{+}+\mathrm{CO}_{3}^{2+}+\mathrm{H}^{+}=\mathrm{NaHCO}_{3}^{-}$ & 10.080 \\
\hline $\mathrm{Na}^{+}+\mathrm{SO}_{4}^{2-}=\mathrm{NaSO}_{4}^{-}$ & 0.700 \\
\hline $\mathrm{K}^{+}+\mathrm{SO}_{4}^{2}=\mathrm{KSO}_{4}^{-}$ & 0.850 \\
\hline \multicolumn{2}{|l|}{ Minerals and Gases } \\
\hline $\mathrm{H}_{2} \mathrm{CO}_{3}^{\cdot}=\mathrm{CO}_{2}$ (gas) $+\mathrm{H}_{2} \mathrm{O}$ & -1.466 \\
\hline $\mathrm{Ca}^{2+}+\mathrm{CO}_{3}^{2+}=\mathrm{CaCO}_{3}$ (calcite) & -8.470 \\
\hline $\mathrm{Ca}^{2+}+\mathrm{SO}_{4}^{2+}+2 \mathrm{H}_{2} \mathrm{O}=\mathrm{CaSO}_{4}^{\circ} \cdot 2 \mathrm{H}_{2} \mathrm{O}$ (gypsum) & -4.602 \\
\hline
\end{tabular}

\subsection{Mineralogical Data}

Mineralogic data are needed to constrain geochemical models that involve the interaction of groundwater with the solid grains of the aquifer. Mineralogic data available for this study are contained in lithologic logs of drill cores and cuttings. Detailed core logs were available for SFR-1D, SFR-2S, SFR-3P, SFR-3T, and SFR-4T. Logs without much mineralogic detail were available for Burn Site, CWL-BW2, EOD Hill, Golf Course South, KAFB-10, MVMW-J, MVMW-K, MWL-BW1, NW-TA3, and Tijeras East; no logs were available for the other wells. A summary of the mineralogy as compiled from these logs is provided in Appendix $\mathbf{E}$. 
Table 2-4. Parameters Calculated With PHREEQE

\begin{tabular}{|c|c|c|c|c|c|c|}
\hline \multirow[b]{2}{*}{ Sampling Location } & \multirow[b]{2}{*}{$\begin{array}{l}\text { Ionic } \\
\text { Strength }\end{array}$} & \multirow{2}{*}{$\begin{array}{c}\text { Total } \\
\text { Inorganic } \\
\text { Carbon } \\
(\mathrm{mg} / \mathrm{L})^{2} \\
\end{array}$} & \multirow[b]{2}{*}{$\begin{array}{c}\text { Cation/ } \\
\text { Anion Ratio }\end{array}$} & \multicolumn{2}{|c|}{ Saturation Index } & \multirow{2}{*}{$\begin{array}{l}\log P_{\infty} \\
(\text { atm }\end{array}$} \\
\hline & & & & Calcite & Gypsum & \\
\hline Burn Site Well & 0.014 & 69.10 & 1.03 & -0.29 & -1.264 & -1.40 \\
\hline Coyote Springs & 0.044 & 486.30 & 1.04 & -0.05 & -1.320 & -0.17 \\
\hline CWL-BW2 & 0.017 & 113.78 & 1.02 & 0.06 & -1.576 & -122 \\
\hline EOD Hill Well & 0.067 & 1175.20 & 1.00 & 0.39 & -1.121 & 0.24 \\
\hline Golf Course South & 0.009 & 32.22 & 1.31 & -0.06 & -1.694 & -2.16 \\
\hline Greystone & 0.014 & 99.72 & 1.05 & 0.06 & -1.837 & -1.35 \\
\hline Hubbell Spring & 0.013 & 128.25 & 0.98 & -0.98 & -1.362 & -0.76 \\
\hline KAFB-10 & 0.007 & 16.36 & 0.91 & -0.55 & -2.244 & -2.69 \\
\hline LF/DM-01 & 0.004 & 23.87 & 1.01 & 0.07 & -2.370 & -2.86 \\
\hline LF/DM-02 & 0.008 & 45.60 & 1.04 & 0.05 & -1.680 & -2.04 \\
\hline MVMW-J & 0.006 & 41.43 & 1.01 & 0.33 & -2.239 & -2.46 \\
\hline MVMW-K & 0.006 & 40.62 & 0.97 & 0.66 & -2.167 & -2.79 \\
\hline MWL-BW1 & 0.009 & 59.18 & 1.12 & 0.24 & -2.050 & -2.09 \\
\hline NW-TA3 & 0.008 & 38.82 & 1.05 & 0.08 & -1.748 & -2.25 \\
\hline Schoolhouse & 0.018 & 124.43 & 0.98 & 0.09 & -1.656 & -1.16 \\
\hline Sol se Mete Spring & 0.01 & 58.66 & 1.05 & 0.27 & -1.656 & -1.92 \\
\hline SFR 1 & 0.019 & 145.08 & 1.01 & 0.07 & -1.598 & -1.03 \\
\hline SFR 2 & 0.016 & 103.01 & 0.99 & -0.04 & -1.611 & -1.25 \\
\hline SFR 3P & 0.016 & 100.44 & 0.98 & -0.03 & -1.513 & -1.28 \\
\hline SFR 3T & 0.062 & 4.05 & 1.01 & -0.53 & -0.049 & -3.24 \\
\hline SW-TA3 & 0.007 & 45.29 & 1.07 & 0.73 & -2.108 & -2.86 \\
\hline Tijeras East & 0.009 & 54.28 & 0.96 & 0.15 & -1.564 & -1.95 \\
\hline SFR 4T & 0.0665 & 27.56 & 1.2 & -0.47 & -0.956 & -2.51 \\
\hline PL-3 & 0.0074 & 43.68 & 1 & -0.26 & -1.783 & -1.88 \\
\hline TRN-1 & 0.0213 & 209.08 & 0.95 & -0.07 & -1.769 & -0.813 \\
\hline MRN-2 & 0.007 & 42.18 & 1.01 & -0.19 & -1.885 & -2.02 \\
\hline TJA-2 & 0.008 & 28.95 & 1.12 & -0.15 & -1.737 & -2.19 \\
\hline
\end{tabular}

- $\quad \mathrm{mg} / \mathrm{L}=$ milligrams per liter.

atm $=$ atmosphere. 
Table 2-5. Most Representative Data Used in This Investigation

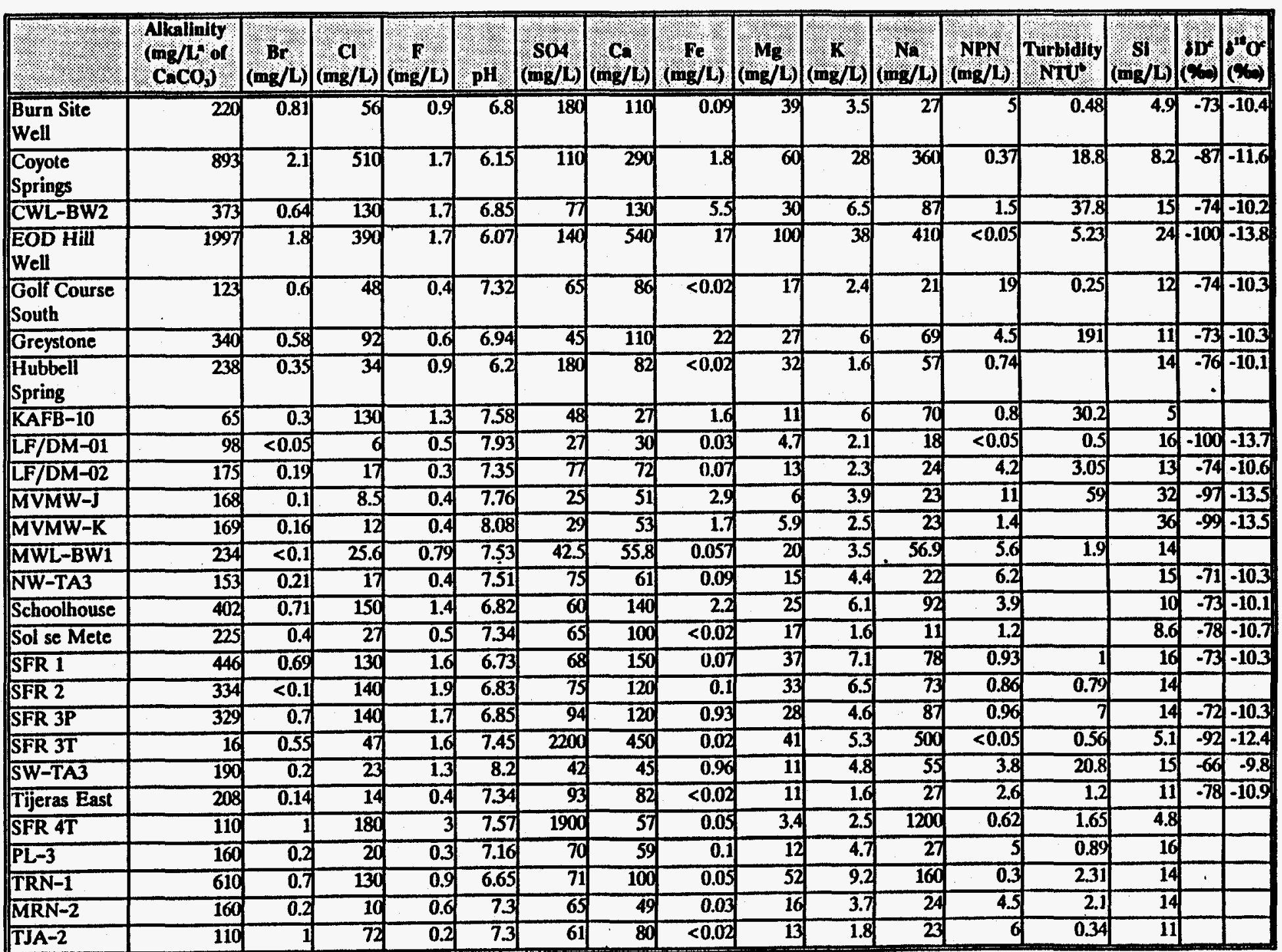

$\mathrm{mg} / \mathrm{L}=$ milligrams per titer.

- $\quad$ NTU = nephelometric turbidity unit.

- $8 D$ and 8 8"O values are from the September 1994 sampling. 


\subsection{Overview of Modeling Methods}

Two types of geochemical modeling were used in this study: (1) mass-balance and (2) reaction-path. In the mass-balance approach, two groundwater analyses from the same (assumed) flow path are compared. If differences exist in the chemistries of chemical components, they are explained by mass transfer between the groundwater and the solid phases in the aquifer. Evaporation and mixing with other groundwater can also be modeled. For example, if chloride concentration increases from the upgradient to the downgradient sample, it could be that a chloride-bearing mineral (for example halite) dissolved, that an ion exchanged with chloride on a clay mineral surface, that water was lost through evapotranspiration, or that mixing occurred with a high-chloride groundwater. The selection of the correct process involves assimilating all available information about the rock types, groundwater hydrology, climate, and other groundwater chemical components. Rarely, if ever, will a unique set of chemical processes be defined.

With the mass-balance approach, multiple models can be defined that exactly match the observed results. With thermodynamic considerations, some of these models may be eliminated. For example, if a model requires gypsum to be precipitated, but gypsum is undersaturated in both the upgradient and downgradient groundwater samples, this model could be eliminated. The accuracy of the thermodynamic data must be considered when applying these criteria. In the gypsum example, if the solutions are only slightly undersaturated and the amount of gypsum precipitated is small, the model may be viable. Some subjectivity is usually involved on the part of the geochemist in making these determinations.

The mass-balance approach is an inverse problem in that the final composition is used in conjunction with the initial water composition to formulate the models. In contrast, the reaction-path approach is a forward problem, in which only the initial groundwater composition is used as input (Plummer et al. 1983). In the reaction-path approach, the initial groundwater composition is interacted with plausible phases (phases that the modeler has determined are reasonable to occur in the aquifer under consideration) in a stepwise method. At each step, saturation indices for plausible phases are examined. If a phase that was previously undersaturated becomes saturated, then it is necessary at this reaction step to begin to precipitate this phase. Thus, the results of a reaction-path simulation satisfy all thermodynamic constraints (mass-balance modeling does not consider thermodynamics). Therefore, reaction-path methods are preferred if a reasonable reaction path can be found.

The driving force for a reaction-path model is the stepwise addition of an irreversible reaction. The irreversible reaction could be the dissolution (or precipitation) of a mineral phase, the exsolution (or dissolution) of a gas, ion exchange, or a progressive mixing with another water; combinations of these processes could also be used. Time is rarely used as a reaction-progress variable because the required rate constants are typically unknown. 


\subsection{History of Modeling Methods}

A paper by Garrels and Mackenzie (1967) is often cited as the founding work on the mass-balance (called material-balance by them) approach. In Garrels and Mackenzie (1967), the major-ion chemistry of spring water in the Sierra Nevada is modeled by considering interactions between shallow groundwater and the granite through which it passes. The initial composition is assumed to be the composition of an ephemeral spring in the area; the final composition is that of a perennial spring. The approach involved progressively subtracting phases from the final composition. The first step was to remove $\mathrm{Cl}$ by assuming that the $\mathrm{Cl}$ was added to the groundwater by the dissolution of halite $(\mathrm{NaCl})$. Thus, when $\mathrm{Cl}$ was removed, an equimolar amount of $\mathrm{Na}$ was subtracted from the $\mathrm{Na}$ inventory. Plausible phases, including halite, gypsum, kaolinite, $\mathrm{Ca}$ montmorillonite, $\mathrm{CO}_{2}$ gas, calcite, silica, biotite, and plagioclase, were progressively removed to account for the major-ion composition of the final spring water.

The pioneering work of Helgeson (1968) provided a mathematical approach to solve reaction-path simulations. With this approach, both irreversible and reversible (partial equilibrium) reactions are integrated into a series of linear differential equations. These methods have been applied to define reaction paths responsible for mineralogic sequences observed in hydrothermal ore deposits (Helgeson 1979).

The U.S. Geological Survey (USGS) developed the widely used computer codes BALANCE (Parkhurst et al. 1982) and NETPATH (Plummer et al. 1991) to solve mass balance problems and PHREEQE (Parkhurst et al. 1980) to solve reaction-path problems. Plummer et al. (1983) describe the mathematical development of the USGS codes and provide examples of their use. The example used by Plummer et al. (1983) is a study of an aquifer in Florida. The chemistry of groundwater was determined in three wells assumed to lie along a flow path. Twelve mass-balance models were found to satisfy the constraints of seven plausible phases. Carbon and sulfur isotopes were used to further constrain the system and the reaction path. Simulations involved both closed (to $\mathrm{CO}_{2}$ ) and open systems. The purpose of the modeling was to determine what chemical reactions are occurring in the aquifer. Plummer et al. concluded that the processes responsible for the groundwater evolution are irreversible incongruent dolomite dissolution, gypsum dissolution, and sulfate reduction; the system was open to $\mathrm{CO}_{2}$ initially and reaction with organic carbon occurred.

Anderholm (1988) studied the groundwater geochemistry of the Albuquerque-Belen Basin as part of a water resources investigation. Anderholm's study was cited in the GJPO Statement of Work as a model that could be used as a guide in this investigation. Anderholm (1988) presented the geochemical data as spatial plots and Piper diagrams and included modeling that used the Garrels and MacKenzie (1967) material-balance approach to aid in the interpretations of groundwater origins.

For his northern area, which includes the Sandia/KAFB site, Anderholm (1988) concluded that several wells northeast of Albuquerque with relatively low specific conductance are representative of groundwater flowing into the basin from the eastern 
Sandia Mountains. He also indicates that several wells to the northeast of Albuquerque have high $\mathrm{Cl}$ concentrations (to 96 milligrams per liter [mg/L]). These wells are near the basin boundary faults. Anderholm suggests that these elevated $\mathrm{Cl}$ concentrations are related to evolving geothermal water upwelling along the faults.

Note that in all these studies flow paths were assumed and the modeling was used as a tool to help characterize the chemical reactions that are likely to be occurring in the aquifer. Thus, the modeling is used as a characterization tool rather than a diagnostic tool capable on its own of defining flow paths. Even in Anderholm's study, where the goals included interpreting groundwater origins, the flow paths were based on geologic, geohydrologic, and spatial chemistry-not strictly on model results.

\subsection{Mathematical Treatment}

The mass balance approach is described by the following equation (Plummer et al. 1983):

$$
\left\{\sum_{p=1}^{P} \alpha_{p} b_{p, k}=\Delta m_{T, k}\right\} k=1, J
$$

where

$$
\begin{aligned}
& \alpha_{\mathrm{p}} \quad \begin{array}{l}
\text { net mass transfer in moles of the } \mathrm{p}^{\mathrm{t}} \text { plausible phase among the } P \\
\text { total reactant and product phases in the reaction, }
\end{array} \\
& \mathrm{b}_{\mathrm{P}, \mathrm{k}} \quad=\text { stoichiometric coefficient of the } \mathrm{k}^{\text {th }} \text { component in the } \mathrm{p}^{\text {th }} \text { phase, } \\
& \Delta \quad=\text { difference (final value minus initial value), } \\
& \mathrm{m}_{\mathrm{T}, \mathrm{k}} \quad=\text { total molality of the } \mathrm{k}^{\text {th }} \text { component in solution, and } \\
& \mathrm{J} \quad=\text { number of components. }
\end{aligned}
$$

The computer program PHREEQE (Parkhurst et al. 1980) was used to perform the reaction-path calculations. This program solves a set of nonlinear equations that define

(1) electrical neutrality;

$$
\sum_{i=1}^{I} Z_{i} \cdot m_{i}=0
$$


(2) mass balance;

$$
\sum_{i=1}^{I} c_{L j} \cdot m_{i}=T O T_{j}+\sum_{p=1}^{P} b_{p j} \cdot M I N_{p} \text { for each } j
$$

(3) mineral equilibrium;

$$
\sum_{j=1}^{J} b_{p j} \cdot \log \left(a_{j}\right)=\log \left(K_{p}\right) \text { for each } p
$$

and (4) mass action for aqueous species

$$
\log \left(a_{i}\right)=\log \left(K_{i}\right)+\sum_{j=1}^{J} c_{i j} \cdot \log \left(a_{i}\right)
$$

where

$$
\begin{aligned}
& \text { I = number of aqueous species, } \\
& Z_{i}=\text { charge on the } i^{\text {th }} \text { species, } \\
& \mathrm{m}_{i} \quad=\text { molarity of the } i^{\text {th }} \text { aqueous species, } \\
& c_{i, j}=\text { stoichiometric coefficient of the } j^{\text {th }} \text { master species in the } i^{\text {th }} \\
& \text { aqueous species, } \\
& \text { TOT }_{j}=\text { total concentration of the element corresponding to the } j^{\text {th }} \text { master } \\
& \text { species preceding any mineral dissolution or precipitation, } \\
& \mathbf{P} \quad=\text { number of mineral phases, }
\end{aligned}
$$

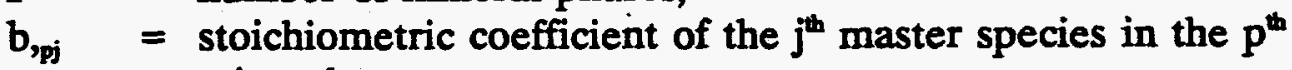

$$
\begin{aligned}
& \text { mineral, } \\
& \mathrm{MIN}_{\mathrm{p}}=\text { moles of the } \mathrm{p}^{\mathrm{t}} \text { mineral transferred into }(+) \text { or out of }(-) \text { the } \\
& \text { aqueous phase, } \\
& \mathrm{J} \quad=\text { number of master species, } \\
& a_{j} \quad=\text { activity of the } j^{\text {th }} \text { master species, } \\
& a_{i} \quad=\text { activity of the } i^{\text {th }} \text { ion pair, and } \\
& \mathrm{K}_{i} \quad=\text { equilibrium constant for the mass action equation for the } i^{\text {th }} \\
& \text { species. }
\end{aligned}
$$

PHREEQE has a flexible input that allows the user to drive the chemical equilibrium with an (or a set of) irreversible reaction steps. 


\subsection{Model Assumptions and Uncertainties}

Multiple mass-balance models can be defined to satisfy all known geochemical constraints for a groundwater system. Elimination of those models that are less likely to reflect reality involves assimilating all other site information (e.g., groundwater hydrology, geology, climate) that bears on the analysis. Sufficient information is rarely available on the composition of the subsurface; thus, the list of plausible phases (and their exact chemical compositions) is usually a major source of uncertainty.

More than one irreversible process probably occurs simultaneously to drive the chemical evolution of most groundwater systems. The relative rates of the driving reactions are required to accurately model these systems; however, these rates are seldom known.

In the literature examples of mass-balance and reaction-path models such as those summarized in Section 3.1, the two or more groundwaters being modeled are assumed to be located along a flow path. The purpose of the modeling was to determine what chemical reactions caused the observed changes in groundwater composition. The modeling exercise was aimed at limiting the number of chemical reactive models that satisfied the constraining data. The reactive processes used in these models were then believed to represent the most likely processes that occur in the aquifer.

In contrast to a goal of understanding chemical processes occurring in the aquifer, the primary goal of the current study at Sandia/KAFB was to define groundwater flow paths and recharge areas. To accomplish this goal, we wish to test the hypothesis that two groundwater samples are located on the same flow path. Compositions of the two groundwaters are compared and modeled. Models are evaluated and are accepted if they provide a reasonable explanation of the groundwater system. The test of "reasonableness" is necessarily subjective because no unique solutions are found. Thus, a geochemical evaluation is best used to help evaluate conceptual models derived from geologic and groundwater hydrologic investigations.

Because of the uncertainty that is inherent in sampling and analyzing groundwater, small differences in analytical values between two wells may not reflect geochemical processes. Thus, the interpretations made in the following sections emphasize the largest compositional variations.

\subsection{Statistical Evaluation}

A statistical evaluation was performed to determine if any of the differences in analytical values between two wells could be solely the result of random sampling and analysis uncertainties. If so, the analyte may have been "conserved" along the flow path without having undergone any chemical reaction. The statistical evaluation is used to determine which elements display the largest variation. 
The statistical analysis, however, cannot prove that an element is conserved. Take, for example, $\mathrm{Ca}$ which is controlled by calcite dissolution. Dilution of a calcite-equilibrated groundwater followed by the addition of $\mathrm{Ca}$ due to re-equilibration would produce the original $\mathrm{Ca}$ concentrations and, yet, $\mathrm{Ca}$ would not have been conserved.

\subsubsection{Methods}

T-statistics were computed for the three pairs of wells used in the interpretive section (Section 5). The data are from up to eight sampling rounds (Appendix A). SFR-4T has only one sampling period, so a statistical evaluation could not be performed. Suspect data were not used in the evaluation. The variances due to sampling and analysis imprecision should be normally distributed, which meets the requirement of the T-test method.

As an example of the T-test method, pairs of chloride data used in the comparison of EOD Hill well and Coyote Springs (Appendix A) are 422.7/523.2, 434.1/528.2, 410/420, $420 / 410,400 / 510,420 / 530,390 / 540,390 / 510$, and 369/500. The computed T-statistic is 5.0 , whereas the tabulated value for $\alpha=0.05$ is 2.3 , indicating that the variation is outside the range attributed to random fluctuations. It is concluded that $\mathrm{Cl}$ concentrations are significantly different between these two wells.

\subsubsection{Results}

The results of the statistical evaluation are presented in Table 3-1. With the exception of $\mathrm{SO}_{4}$ and $\mathrm{pH}$ in the EOD Hill/Coyote Springs pair and $\mathrm{SO}_{4}$ in the SFR-3P/EOD Hill pair, all analytes showed variation in excess of that expected due to random sampling and analysis imprecision. 
Table 3-1. Results of T-Tests

\begin{tabular}{|c|c|c|c|c|c|c|c|c|c|}
\hline & EOD Hill & $\begin{array}{l}\text { Soyote } \\
\text { Springs }\end{array}$ & \multirow[b]{2}{*}{ Ressilt } & $\mathrm{CW}-\mathrm{BW}$ & $M W=B W$ & \multirow[b]{2}{*}{ Result } & $S F R-3 P$ & $\begin{array}{l}\text { EOD } \\
\text { Hili }\end{array}$ & \multirow[b]{2}{*}{ Resulto } \\
\hline & & $\sqrt{4 t}$ & & t. & (1) & & 18 & 18 & \\
\hline$\overline{\mathrm{Ca}}$ & $\overline{17.9}$ & $\overline{2.4}$ & + & 15.0 & $\overline{2.4}$ & + & $\overline{66.4}$ & 3.2 & $\bar{t}$ \\
\hline $\mathrm{Na}$ & 5.4 & 2.4 & $T$ & 15.9 & 2.4 & + & 125.1 & 3.2 & $t$ \\
\hline$\overline{\mathbf{K}}$ & $\overline{8.4}$ & 2.3 & + & 49.5 & 2.4 & $t$ & 157.4 & $\overline{3.2}$ & + \\
\hline$\overline{M g}$ & 20.8 & $\overline{2.4}$ & + & 18.8 & 2.4 & + & 31.0 & $\overline{3.2}$ & + \\
\hline Alk & 14.3 & 2.6 & + & 8.0 & 2.6 & + & 34.3 & 3.2 & + \\
\hline $\mathrm{SO}_{4}$ & $\overline{1.3}$ & 2.4 & 0 & $\overline{6.6}$ & 2.4 & + & 3.2 & 3.2 & $\overline{0}$ \\
\hline CI & 5.0 & 2.3 & + & 35.8 & 2.6 & $t$ & 20.6 & 3.2 & + \\
\hline $\mathrm{pH}$ & 2.0 & 2.3 & $\overline{0}$ & 7.6 & 2.4 & + & 25.6 & 3.2 & + \\
\hline
\end{tabular}

$t$ Calculated $t$ statistic.

* $t$ Rejection $t$ value for $\alpha$ of .05 .

c + result means the two populations are significantly different at the $\alpha=.05$ level.

0 Result means no significant difference in the 2 populations. 


\subsection{Description of the Sandia/KAFB Site}

This section summarizes the geology, surface-water hydrology, groundwater hydrology, groundwater geochemistry, and mineralogy as they pertain to the current project. More detailed descriptions are in Sandia/NM (1994b) and the references in that report. Figure 4-1 presents stratigraphy of the site, and Figure 4-2 presents the geology of the Sandia/KAFB site and wells.

\subsection{Geology}

The Sandia/KAFB site lies in the boundary area between crystalline bedrock mountains (Manzanita Mountains) to the east and Tertiary/Quaternary basin fill to the west. Major northeast-southwest trending faults are characteristic of rifting (crustal extension) processes that formed the basin. The Manzanita Mountains are composed of Precambrian schist, gneiss, and granite that is capped by Paleozoic sediments. In the transition zone faults, exposed blocks of basement (such as the block of Madera Limestone exposed at EOD hill) exposed indicate a complex structural history.

The basin fill is a thick (more than 14,500 feet) sequence of alluvial fans deposited from the eastern highlands and fluvial sediments from the Rio Grande River. These deposits predominately consist of the Tertiary Santa Fe Group with a thin Quaternary alluvial cover. The sedimentary grains consist of quartz, clay, pumice fragments, and a wide variety of lithic fragments including granite, schist, greenstone, limestone, and clastics.

\subsection{Surface-Water Hydrology}

Groundwater is likely to be influenced by the Rio Grande River, a major perennial north-to-south flowing stream located about 5 miles west of the site boundary. Much of the Rio Grande water is diverted into irrigation ditches. The Rio Grande loses water to the aquifer in the vicinity of Sandia/KAFB (Yapp 1985). Two major arroyos (Tijeras and Coyote) drain the mountainous area in the eastern portion of the site to the Rio Grande River. Because the valley receives only about 9 inches of precipitation per year and evapotranspiration is high, little vertical infiltration is expected into the Santa $\mathrm{Fe}$ Group. The Sandia/NM Site-Wide Project is collecting infiltration data to help determine if all or almost all the vertical recharge into the basin fill is from arroyos during flood stages.

As much as $\mathbf{3 0}$ inches of precipitation falls in the mountains east of the Sandia/KAFB site. The higher precipitation and lower evapotranspiration are likely to produce greater infiltration and groundwater recharge in the mountains than in the valley. 


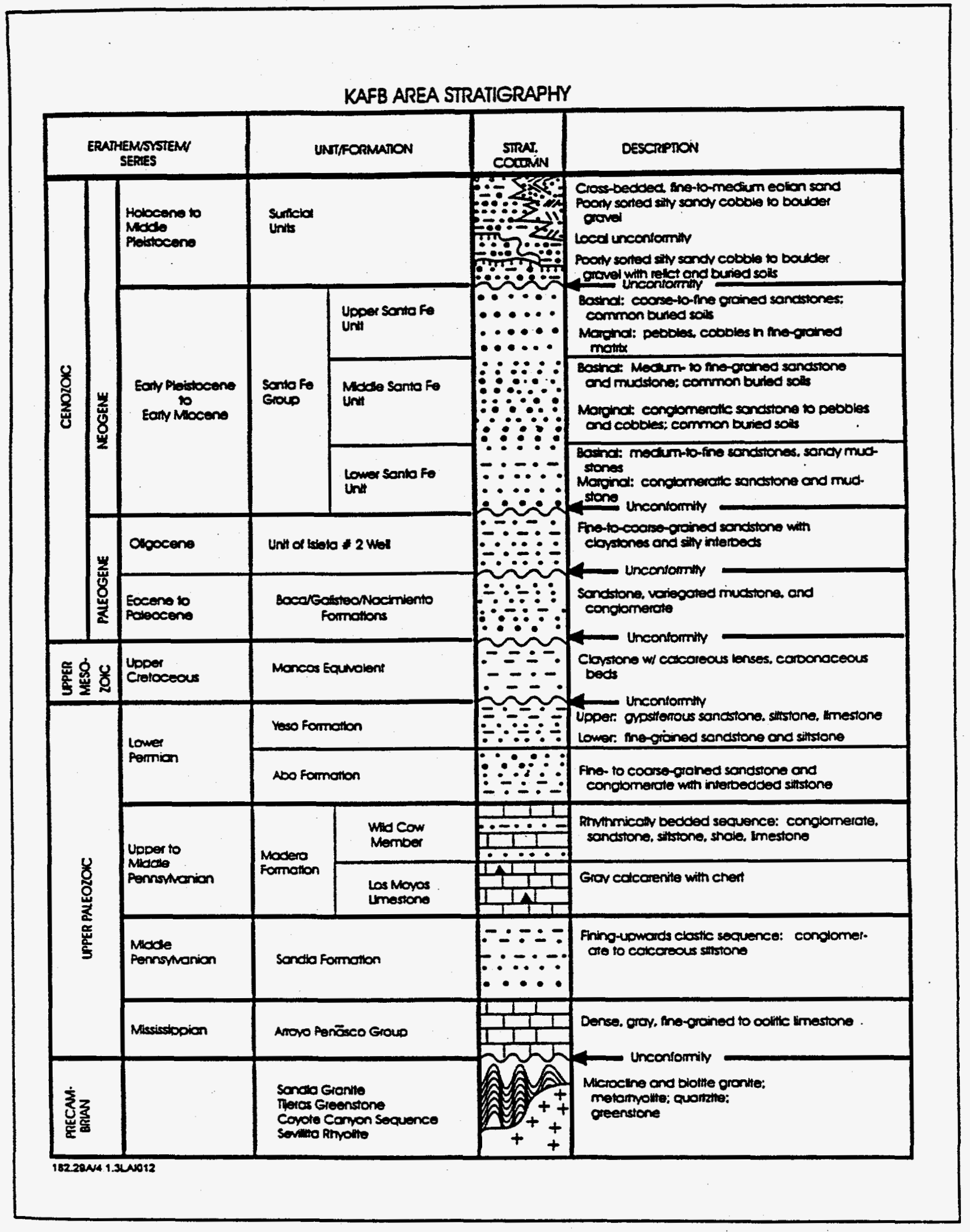

Figure 4-1. Stratigraphic Column for the Sandia/KAFB Area (Sandia 1993) 


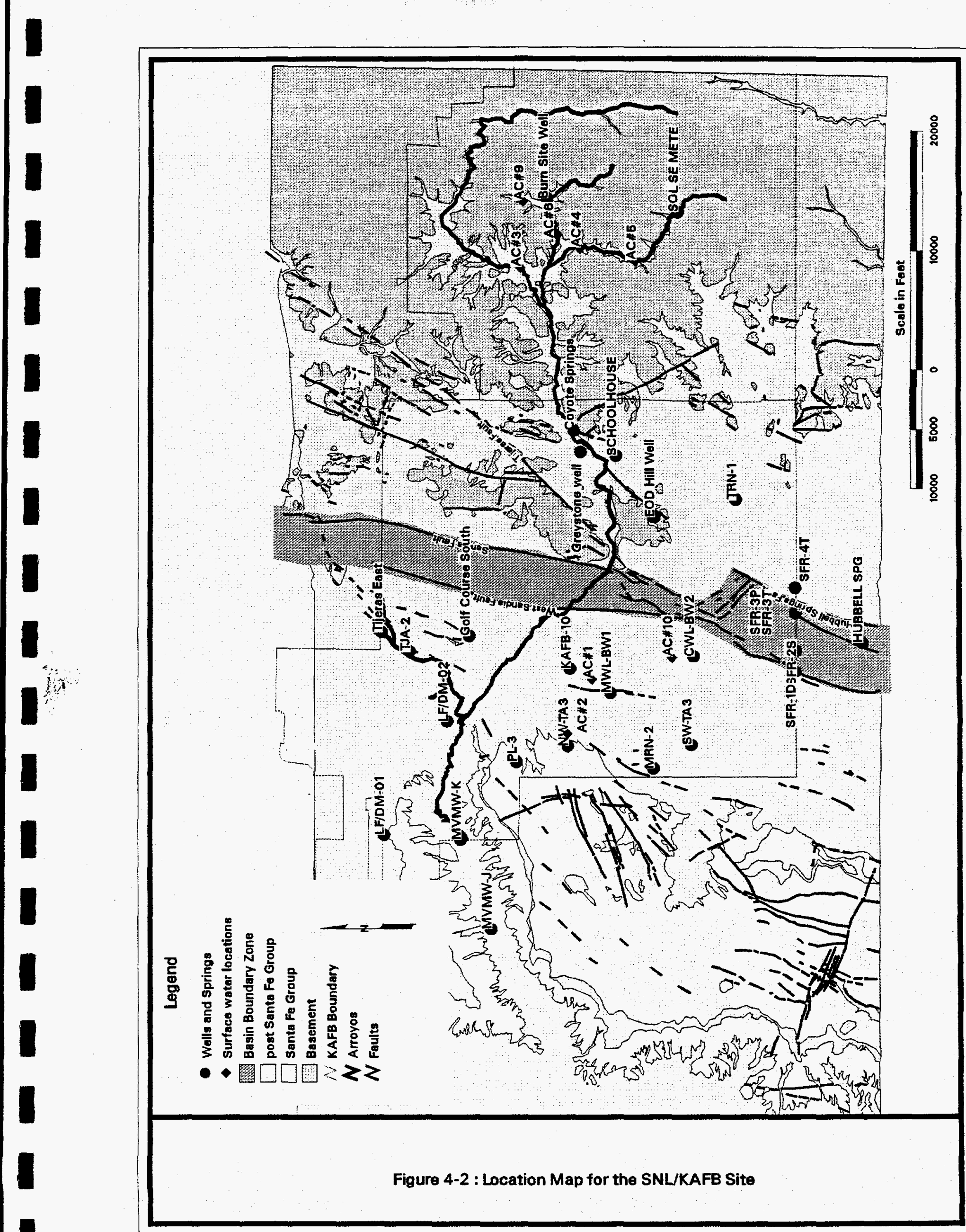




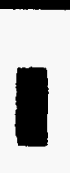

I

|

I

I

I

,

I

I

I

I

I

I

I

,

I

I

I

I 


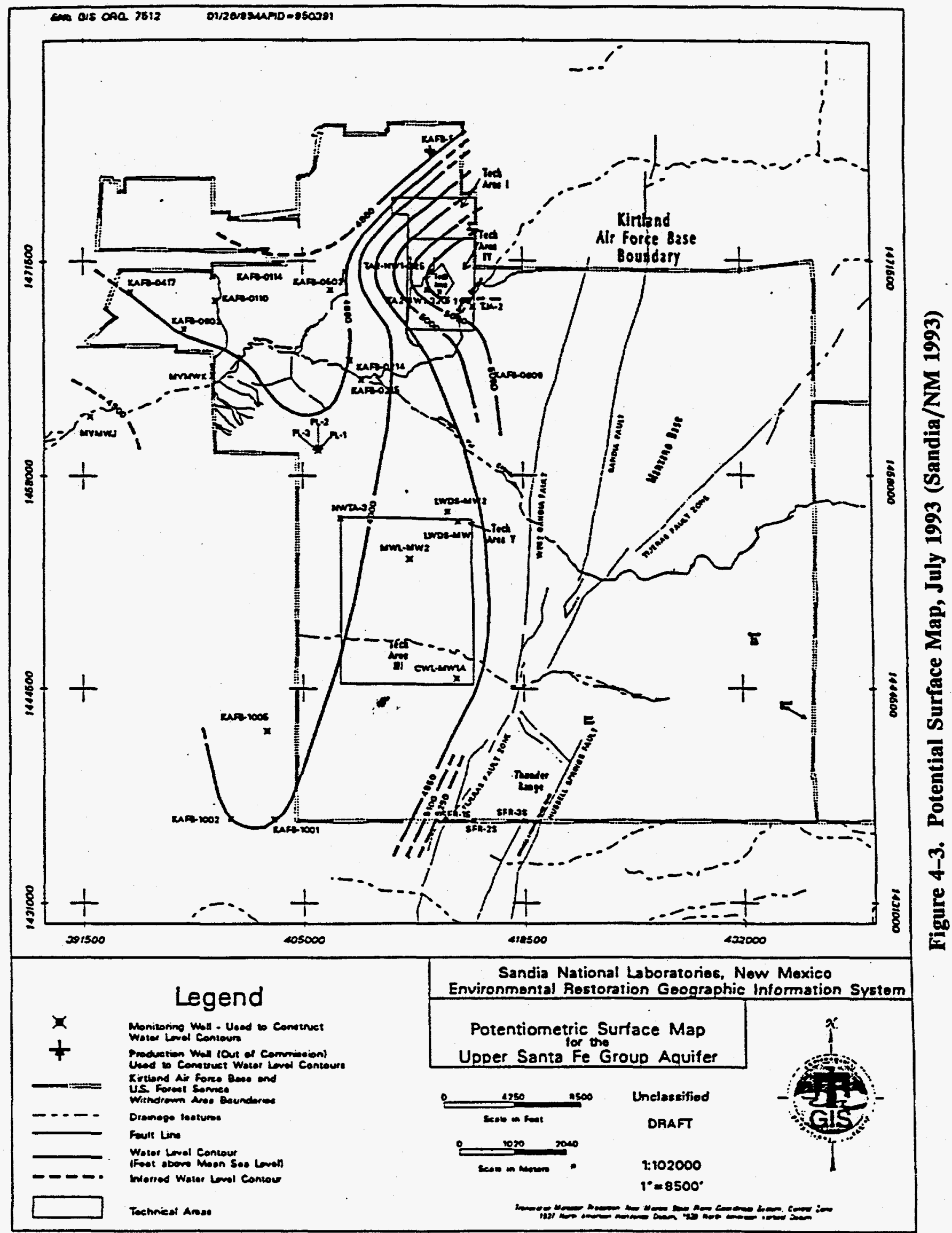




\subsection{Groundwater Hydrology}

Figure 4-3 shows a potentiometric map of the groundwater for the Sandia/KAFB site. Data for this map are from wells with screens in a variety of geologic units. Although the map is probably an accurate portrayal of the regional water table, local perturbances are likely. Regionally, groundwater flows from the highlands toward the valley floor; east to west across the site. Groundwater also flows easterly from the Rio Grande River. Pumping from the Santa Fe Group aquifer for the city of Albuquerque causes the cone of depression seen in the 4900-foot contour on Figure 4-3. This pumping adds a northwest component to the groundwater flow direction at the site.

\subsection{Groundwater Major-Ion Geochemistry}

Figure 4-4 is a Piper diagram of the MRD for the Sandia/KAFB site. Piper diagrams plot concentration ratios, expressed in milliequivalent (meq) per liter of major dissolved ions, and are useful for classifying groundwaters. Each groundwater analysis is plotted on a cation triangle, an anion triangle, and a diamond-shaped cation-plus-anion plot. The cation ( $\mathrm{Ca}, \mathrm{Mg}$, and $\mathrm{Na}$ plus $\mathrm{K}$ ) triangle is divided into four equivalent triangles. Points falling into the apical triangles are said to be dominated by that cation, whereas those in the center do not portray a particular dominance. The anion triangle is also divided into four equivalent triangles. Clusters of data may indicate similar origins. Data presented in Figure 4-4 indicate that most of the groundwater at the Sandia/KAFB site is calcium-bicarbonate type. Groundwater from KAFB-10 is sodiumchloride type and from SFR-3T is calcium/sodium-sulfate type.

The spatial distribution of $\mathrm{Cl}$ is shown as a spot plot in Figure 4-5. The size of the spot indicates the concentration of $\mathrm{Cl}$ at that location. Each spot is labeled with the concentration in milligrams per liter. All wells west of the Hubbell Springs Fault are screened in the Santa Fe Group, while those east of the fault are screened in a variety of formations (Table 2-1). Figure 4-6 shows the distribution of $\mathrm{Cl}$ concentrations for only those wells that are screened in the Santa $\mathrm{Fe}$ Group. The distribution of $\mathrm{Cl}$ indicates relatively high concentrations in the Santa Fe Group near the faults, with progressively lower concentrations in the basin to the west. Because two of the wells (KAFB-10 and CWL-BW2) with particularly high $\mathrm{Cl}$ concentrations were screened at greater depths (Table 2-1) than other wells, $\mathrm{Cl}$ concentrations may be contributed from the deep basin. High Cl concentrations in KAFB-10 may be due to sampling problems; the well was sampled without purging (verbal communication with F. Lauffer).

Samples from the EOD Hill well and Coyote Springs display elevated $\mathrm{Cl}$ concentrations (Figure 4-5). These two sampling locations also have elevated concentrations of $\mathrm{Ca}, \mathrm{Na}$, $\mathrm{C}, \mathrm{Mg}, \mathrm{K}, \mathrm{Br}$, and ionic strength (Appendix $\mathrm{C}$ and Table 2-5). As indicated on the Stiff diagrams in Figure 4-7, the groundwater composition of the EOD Hill well is similar to Coyote Springs except for concentrations of $\mathrm{Ca}$ and $\mathrm{HCO}_{3}$. Stiff diagrams provide a graphical display of multiple-ion concentrations that are absolute values, unlike Piper diagrams which are ratios. 


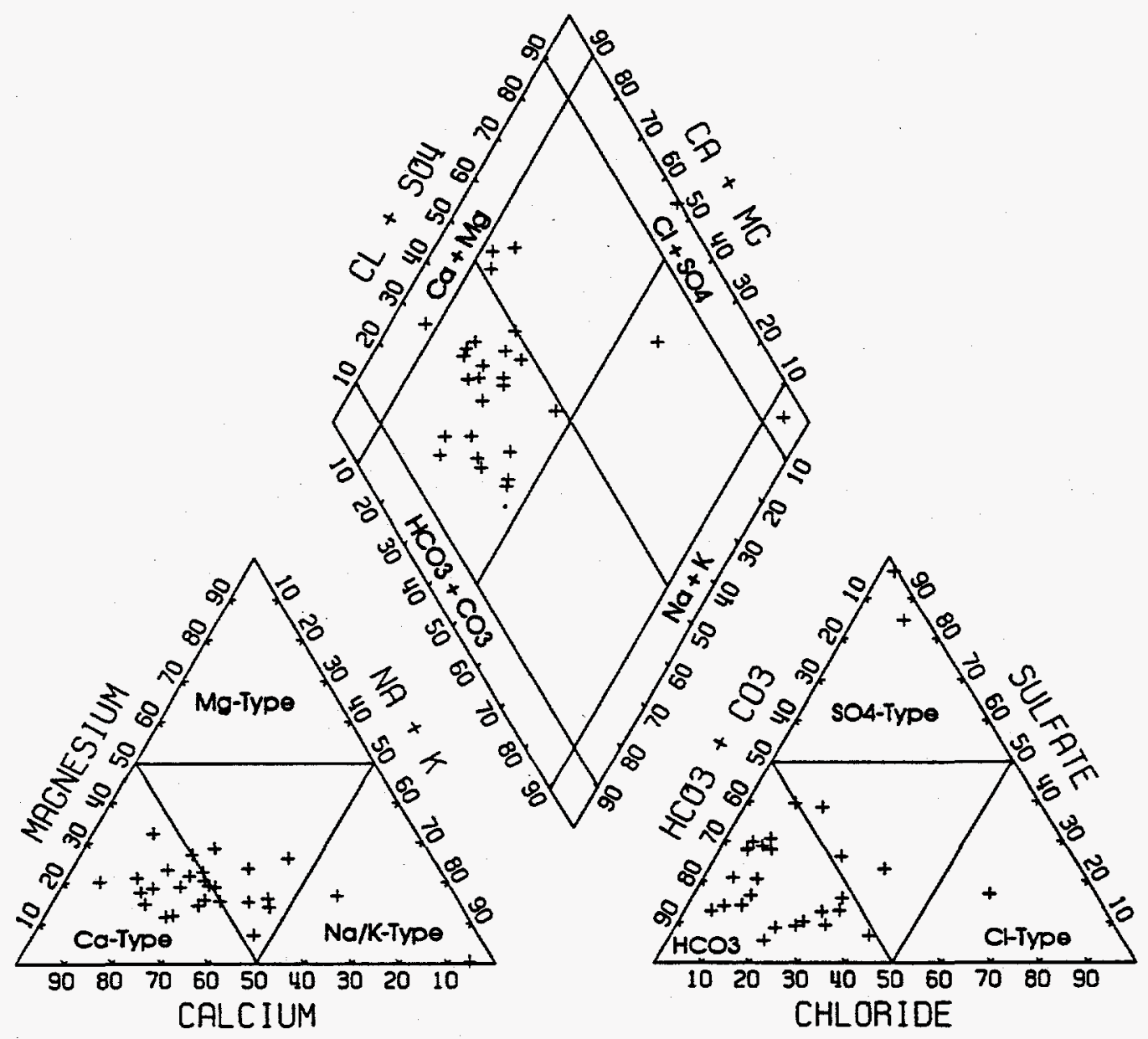

Figure 4-4. Piper Diagram of the MRD from All Wells and Springs Used in This Study $\overline{D O E / G r a n d ~ J u n c t i o n ~ P r o j e c t s ~ O f f i c e ~}$ October 1995

Groundwater Geochemical Study of SNL/KAFB

Page 4-7 


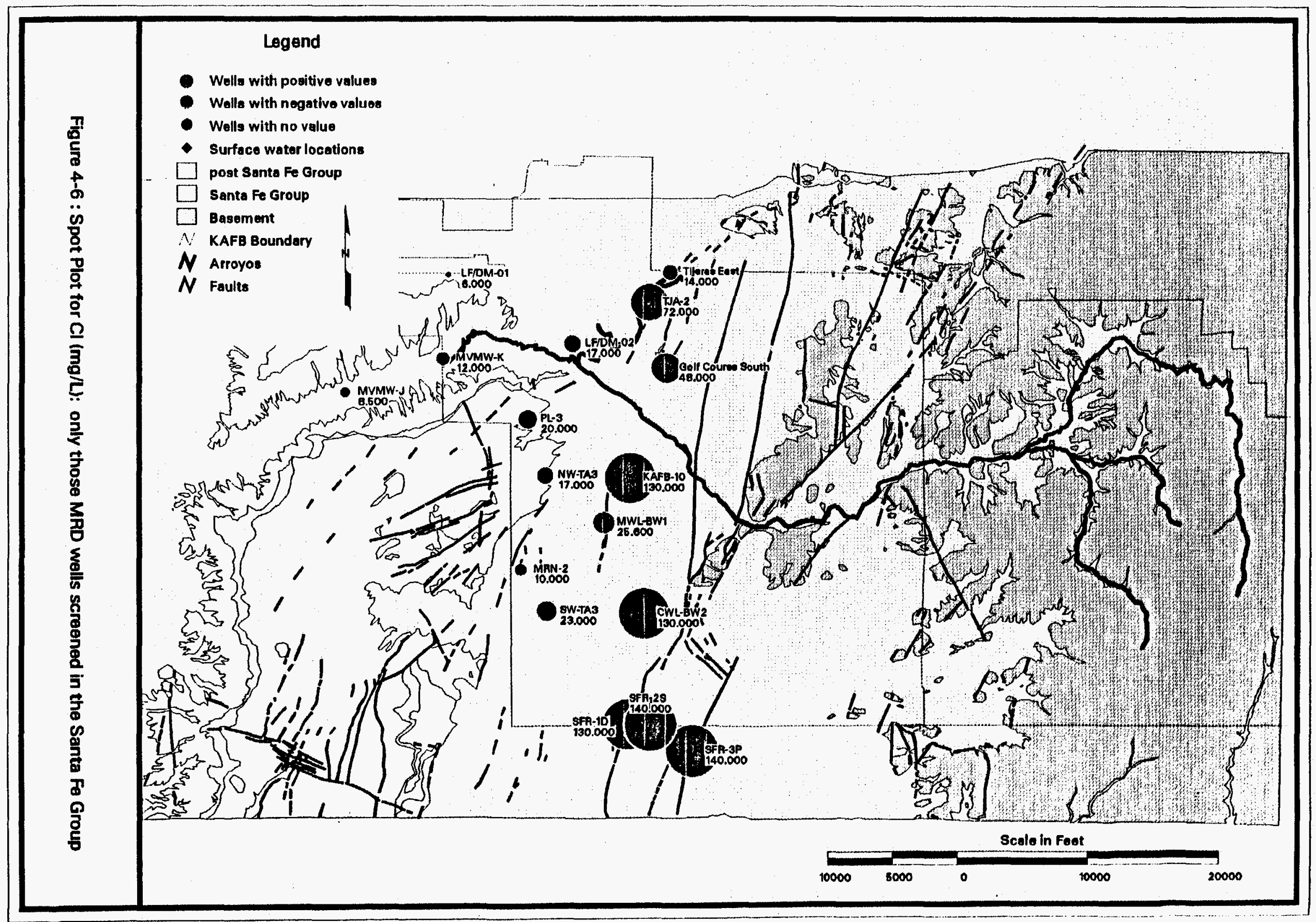



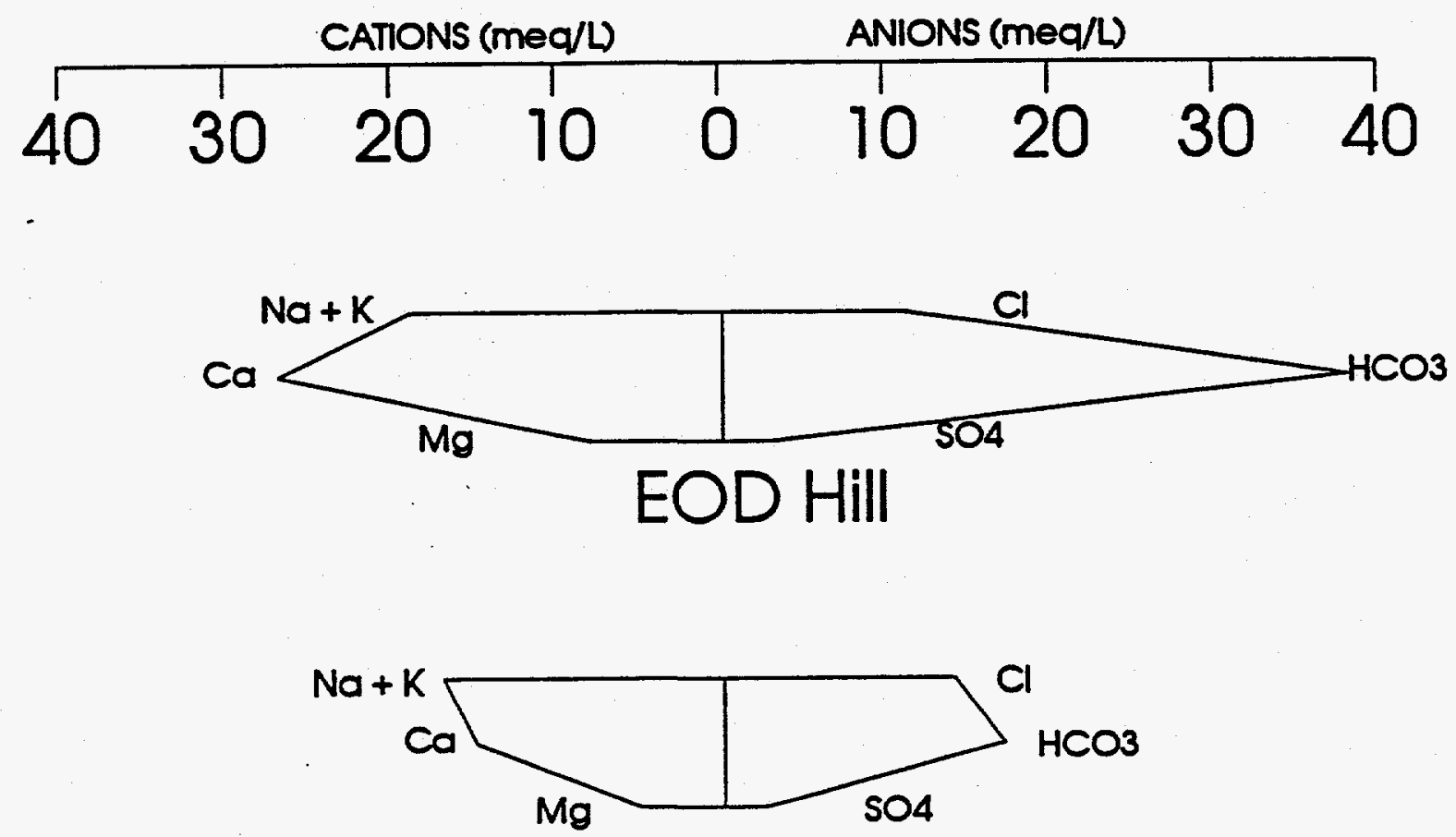

Coyote Springs

Figure 4-7. Stiff Diagrams for EOD Hill and Coyote Spring (MRD) 
Sulfate concentrations in the Santa Fe Group show no obvious trends over the basin. However, SFR-3P, which is closest to the Hubbell Springs fault, has the highest $\mathrm{SO}_{4}$ concentration, whereas MVMW-J, which is farthest from the fault, has the lowest value (Figure 4-8). Five wells (SFR-1, SFR-2, SFR-3P, SFR-3T, and SFR-4T) were sampled in an east-west line along South Fence Road (Figure 4-2). Wells SFR-3P and SFR-3T are 40 feet apart and completed at different levels. SFR-3P is screened from 175 to 195 feet in the Santa Fe Group. SFR-3T crossed the fault and is screened from 713 to 733 feet in the Lower Tertiary unit in the footwall. Well SFR-4T is drilled into the footwall and is screened in Lower Tertiary. Wells SFR-1 and SFR-2 are screened in Santa Fe Group.The groundwater chemistries of the Santa Fe Group wells (SFR-1, SFR-2, and SFR-3P) along South Fence Road are similar (Figure 4-9). The groundwater chemistry of the wells that sample the footwall (SFR-3T and SFR-4T) is substantially different from the hanging wall wells (SFR-1, SFR-2, and SFR-3P), as shown in Figure 4-9. Wells SFR-3T and SFR-4T have high concentrations of $\mathrm{SO}_{4}$, but differ markedly in the cation composition. SFR-3T is high in Ca, whereas, SFR-4T is high in Na plus $\mathrm{K}$.

Nitrate plus nitrite (NPN) concentration is anomalously high at the Golf Course South well (Figure 4-10). This well is located on the golf course where artificial watering has greatly increased the amount of effective precipitation. The MVMW-J well, which is located at a tree farm, is also high in NPN. The high NPN concentrations in Golf Course South and MVMW-J wells are probably due to the application of high-nitrate fertilizers. Groundwater from the Golf Course South well also has the highest cation/anion charge imbalance of any of the samples (Table 2-4 and Appendix C).

\subsection{Stable Isotopes of Oxygen and Hydrogen}

Isotopic data for $\delta \mathrm{D}$ and $\delta^{18} \mathrm{O}$ concentrations in groundwater and surface water samples were collected by Site-Wide Project personnel during June and September 1994 (Tables 4-1 and 4-2).

All values are reported as $\delta \mathrm{D}$ (deuterium) or $\delta^{18} \mathrm{O}$ where

$$
\delta=\left(\frac{R_{\text {Sample }}}{R_{\text {Seandard }}}-1\right) \quad 1000
$$

$R_{\text {Stemple }}$ is the $\mathrm{D} / \mathrm{H}$ or ${ }^{18} \mathrm{O} /{ }^{16} \mathrm{O}$ in the sample and $\mathbf{R}_{\text {sumderd }}$ is the ratio in a standard of ocean water designated Standard Mean Ocean Water or SMOW. Thus, a groundwater sample with $\delta D$ of $-100 \%$ (parts per thousand) is 10 percent lighter than SMOW.

Groundwater $\delta \mathrm{D}$ ranged from -100 to $-61 \%$; $\delta^{18} \mathrm{O}$ ranged from -13.9 to $-8.9 \%$. The lightest ratios were at EOD Hill and the heaviest at KAFB-10. The isotopic values in 


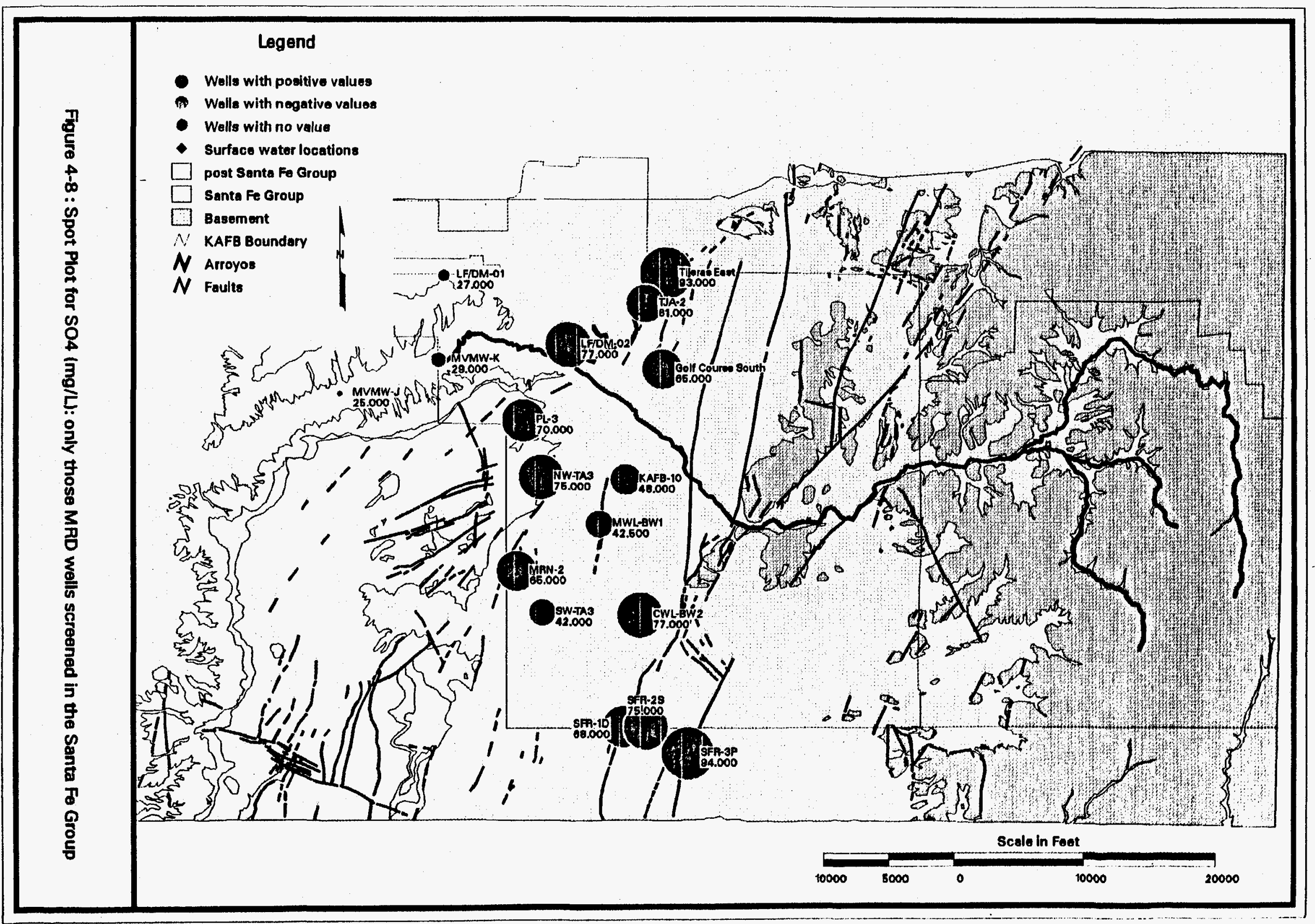



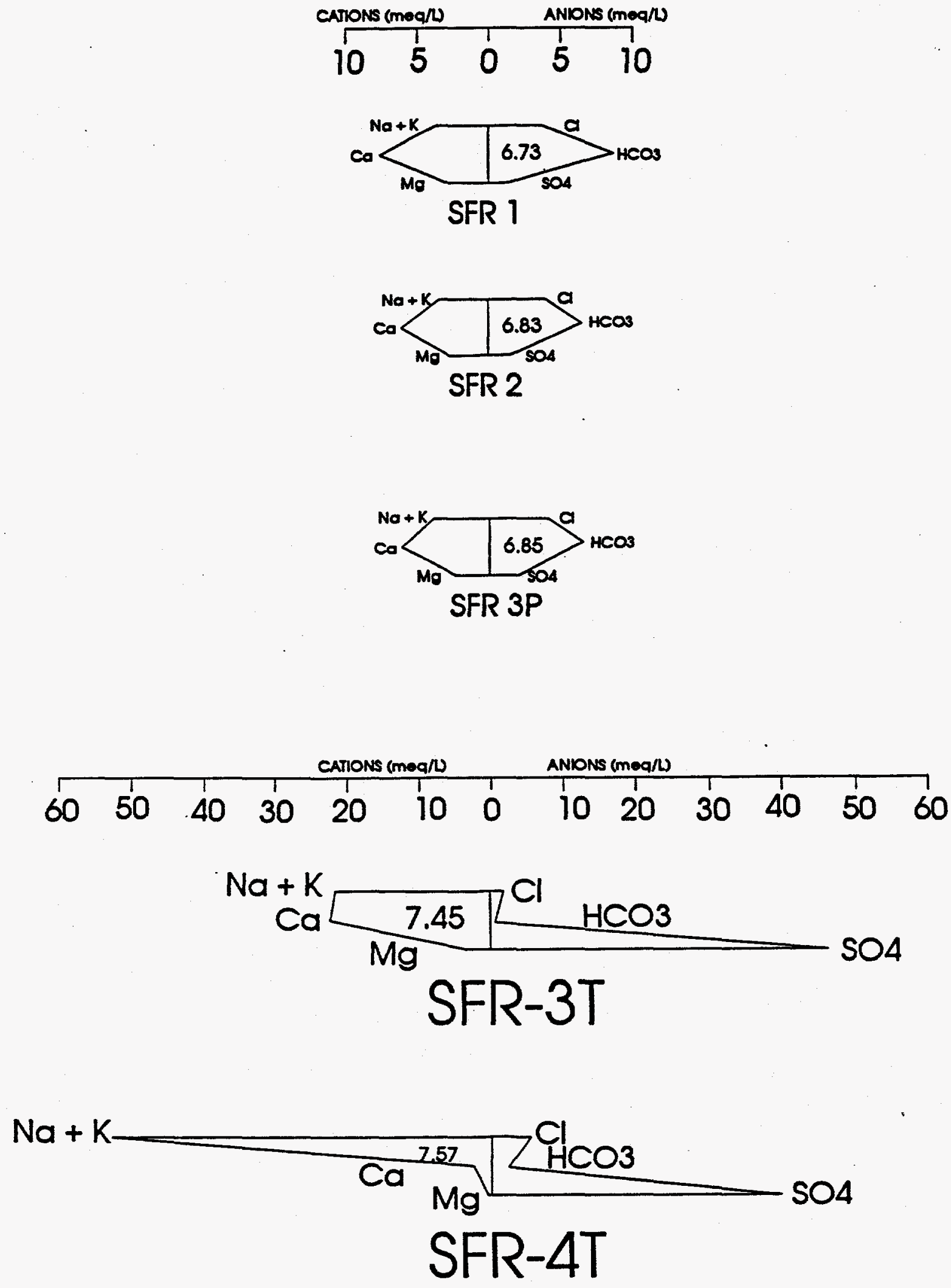

Figure 4-9. Stiff Diagrams for the South Fence Road Wells (MRD) 
KAFB-10 may result from borehole evaporation due to inadequate sampling methods as suggested in Section 4.4. Values of $\delta^{18} O$ and $\delta D$ were significantly higher in the surface water samples ranging from -11.3 to $1.5 \%$ and -80 to $10 \%$, respectively. The small variation in $\delta^{18} \mathrm{O}$ and $\delta \mathrm{D}$ values between the two groundwater samplings (Table 4-1) provides confidence in the analytical precision of the values; the maximum difference in $\delta^{18} \mathrm{O}$ is $0.3 \%$ and in $\delta \mathrm{D}$ values is $5 \%$. This small variation also suggests that the $\delta^{18} \mathrm{O}$ and $\delta \mathrm{D}$ values remain constant over seasons although no spring or winter samplings were made.

Table 4-1. Oxygen and Hydrogen Isotopic Results for Groundwater Collected in 1994

\begin{tabular}{|c|c|c|c|c|}
\hline & \multicolumn{2}{|c|}{$\delta^{2} 0{ }^{3}(5)$} & \multicolumn{2}{|c|}{$\delta \mathrm{D}(\mathrm{x})$} \\
\hline Location & Sune & September & Jine. & September \\
\hline Burn Site & -10.5 & -10.4 & -78 & -73 \\
\hline Coyote Springs & -11.5 & -11.6 & $\overline{-84}$ & -87 \\
\hline CWL-BW2 & -10.2 & -10.2 & -72 & -74 \\
\hline EOD Hill & -13.9 & -13.8 & -100 & -100 \\
\hline Golf Course South & -10 & -10.3 & .74 & -74 \\
\hline Greystone & -10.1 & -10.3 & -73 & .73 \\
\hline Hubbell Spring & -9.9 & -10.1 & -71 & -76 \\
\hline KAFB-10 & -8.9 & & -61 & \\
\hline LF/DM-01 & -13.6 & -13.7 & -100 & -100 \\
\hline LF/DM-02 & -10.6 & -10.6 & .74 & -74 \\
\hline MVMW-J & -13.5 & -13.5 & -97 & -97 \\
\hline MVMW-K & -13.2 & -13.5 & -96 & -99 \\
\hline MWL-BW1 & -9.2 & & -63 & \\
\hline NW-TA3 & -10.4 & -10.3 & -72 & -71 \\
\hline Schoolhouse & -10.2 & -10.1 & -71 & .73 \\
\hline Sol se Mete Spring & -10.7 & -10.7 & -77 & -78 \\
\hline SFR-1 & -10.3 & -10.3 & -72 & .73 \\
\hline SFR-3P & -10.3 & -10.3 & -74 & -72 \\
\hline SFR-3T & & -12.4 & & .92 \\
\hline SW-TA3 & -9.8 & -9.8 & -67 & -66 \\
\hline Tijeras East & -10.6 & -10.9 & -78 & -78 \\
\hline
\end{tabular}

- Data supplied by F. Lauffer (Sandia/NM). 
Table 4-2. Oxygen and Hydrogen Isotopic Results for Surface Water Collected in 1994

\begin{tabular}{|c|c|c|c|}
\hline Gacation & $150(x)$ & $80(5)$ & Date \\
\hline$A C-1$ & 1.5 & 10 & $06 / 19 / 94$ \\
\hline$A C-1$ & -4.5 & -26 & $08 / 01 / 94$ \\
\hline$A C-2$ & 0.7 & 0 & $06 / 19 / 94$ \\
\hline$A C-3$ & -9.4 & -58 & $07 / 21 / 94$ \\
\hline$A C-3$ & -10.3 & -65 & $07 / 26 / 94$ \\
\hline$A C-4$ & -6.7 & -42 & $08 / 01 / 94$ \\
\hline$A C-4$ & -9.5 & -66 & $08 / 15 / 94$ \\
\hline$A C-5$ & -5.6 & -42 & $07 / 17 / 94$ \\
\hline$A C-5$ & -6.1 & -39 & $07 / 31 / 94$ \\
\hline$A C-6$ & -10.5 & -71 & $08 / 15 / 94$ \\
\hline$A C-9$ & -11.3 & -80 & $08 / 15 / 94$ \\
\hline AC-10 & -9.4 & -64 & $08 / 14 / 94$ \\
\hline Coyote Springs & -6 & -42 & $08 / 01 / 94$ \\
\hline
\end{tabular}

a Data supplied by F. Lauffer (Sandia/NM).

In contrast, the surface water $\delta^{18} \mathrm{O}$ and $\delta \mathrm{D}$ values varied significantly between two sampling periods in the same month (Table 4-2). For example, for two August samplings of $A C-4$ the $\delta^{18} \mathrm{O}$ values varied by $2.8 \%$ and $\delta \mathrm{D}$ by $24 \%$. Values of $\delta \mathrm{D}$ for AC-1 varied from -26 to $10 \%$ from June to August.

The $\delta^{18} \mathrm{O}$ and $\delta \mathrm{D}$ results are plotted on Figure 4-11 along with the meteoric water line. The meteoric water line is a best fit line to $\delta^{18} \mathrm{O}$ and $\delta \mathrm{D}$ data from numerous samples of precipitation collected worldwide (Craig 1961). Comparisons to the meteoric water line are universally used to help interpret $\delta^{18} \mathrm{O}$ and $\delta \mathrm{D}$ results. The meteoric water line has the equation

$$
8 D=88^{18} O+10(\%)
$$




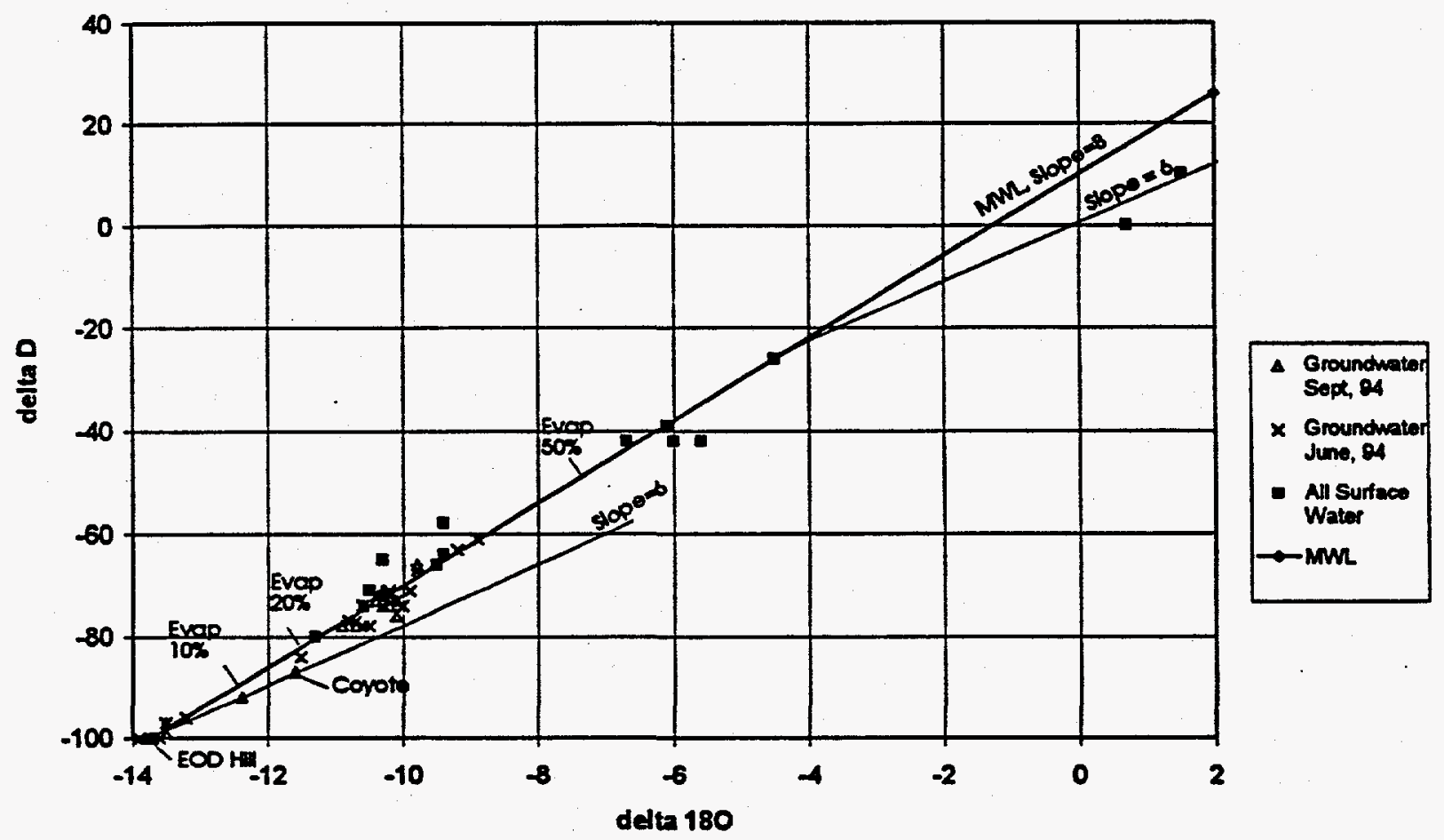

Figure 4-11. $\delta D-\delta^{18} O$ Plot of Water Samples from Sandia/KAFB 
Nearly all groundwater samples from the Sandia/KAFB site plot on or near the meteoric water line. Some samples show modest departures to heavier $\delta^{18} O$ values. The surfacewater samples show larger departures, particulariy for the heaviest two samples.

A spot plot shows that anomalously light $\delta \mathrm{D}$ values occur at EOD Hill and at three wells (LF/DM-01, MVMW-K, and MVMW-J) in the western part of the region closest to the Rio Grande River (Figure 4-12). When only Santa Fe Group wells are examined, two groups of $\delta \mathrm{D}$ values are apparent: a western group with light values ranging from -97 to $-100 \%$ and an eastern group with heavier values ranging from -66 to $-79 \%$ (Figure 4-13).

\subsection{Mineralogy}

This study uses geochemical signatures to understand flow paths of groundwater. As groundwater flows through an aquifer, dissolved chemicals can be transferred to or from solid grains. To reliably predict flow-path chemistry, the availability of reactive solid phases must be known. Data for the mineralogy come from lithologic logs of the wells supplied by Sandia/NM, thin section descriptions of core samples supplied by GRAM, Inc. (subcontractor for the Site-Wide Project), and field observations.

The mineralogy of the detrital grains is reasonably well established from these sources of information. The presence or absence of minor authigenic phases (such as iron oxides) that coat grain surfaces or fill hairline fractures is less well known. Data were not available to determine exact mineral compositions (such as the $\mathrm{Mg}$ content of calcite) or detailed information on crystal structure (such as the amount of smectite in clays). Information on authigenic phases and more detailed mineralogy can be useful in constraining models of groundwater-rock interactions. A summary of the mineralogy of each geologic unit is provided in the following sections.

\subsubsection{Quaternary Alluvium}

Quaternary alluvium refers to all post-Santa Fe Group surficial deposits. No information is available from well logs on the mineralogy. From outcrop observations along Tijeras and Coyote arroyos, the alluvium is composed of silts, sands, gravels, and cobbles compositionally similar to the rocks outcropping in the highland areas. Detrital grains are predominantly quartz and feldspar, with abundant rock fragments of limestone, quartzite, chert, granite, and greenstone (a metamorphosed basic igneous rock). Caliche (calcium carbonate formed from evaporation) horizons are common.

\subsubsection{Santa Fe Group}

The Santa Fe Group is a thick (more than 15,000 feet) sequence of alluvial fan and Rio Grande River deposits containing silt, sand, gravel, and cobbles. Quartz grains, feldspar grains, and clays are abundant throughout the section. Lithic fragments of granite, 

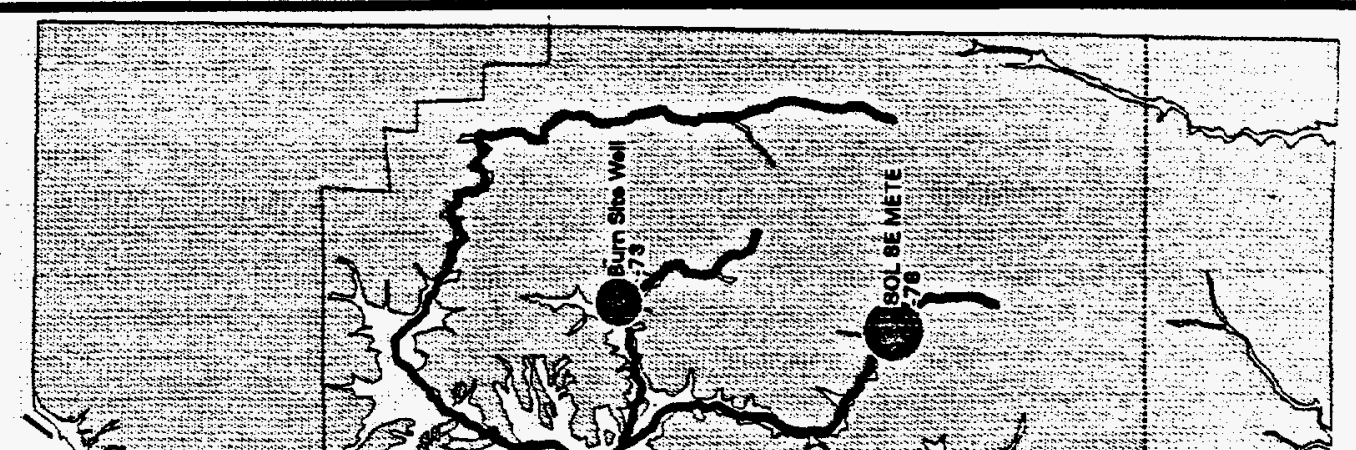

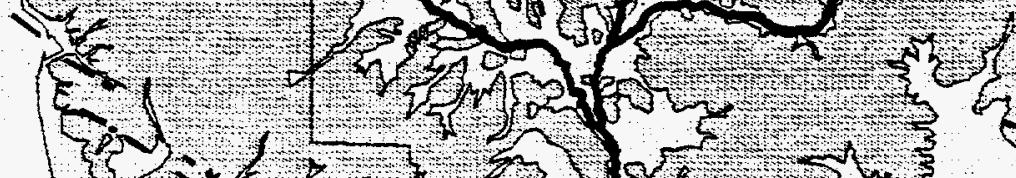

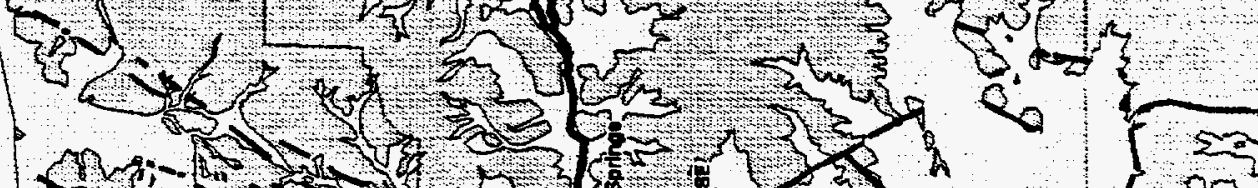

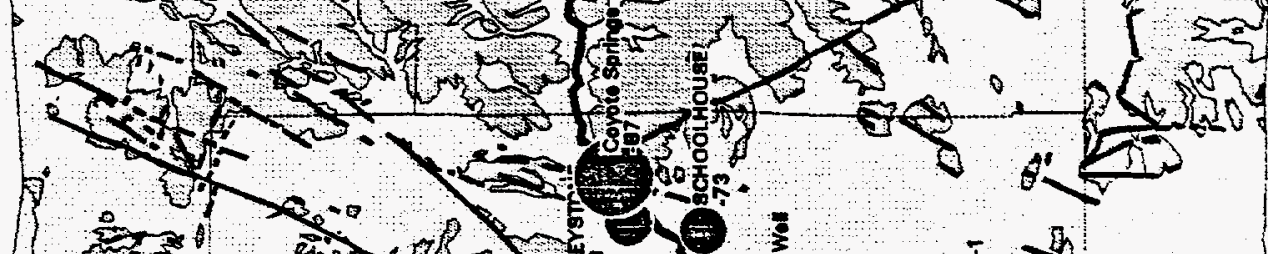

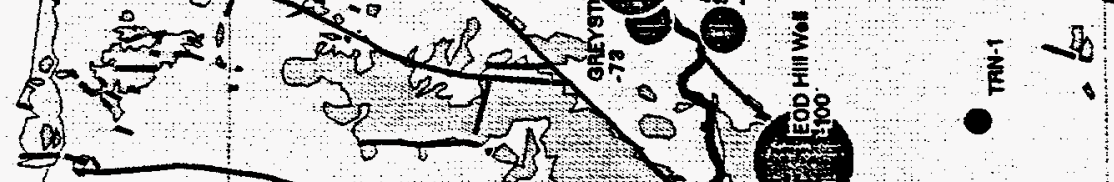

$\frac{20}{3}$

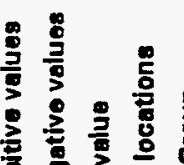

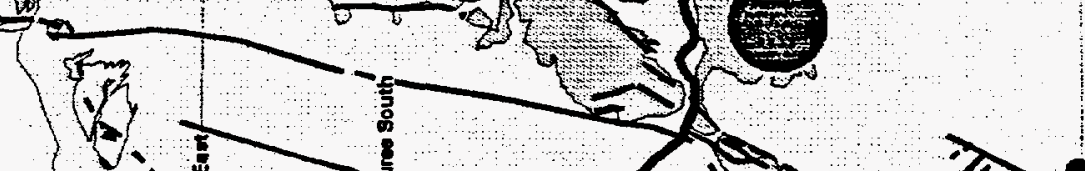

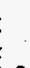

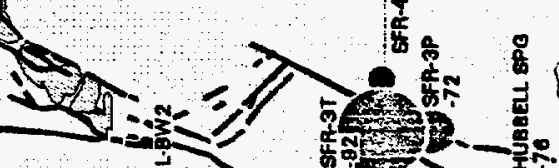

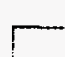

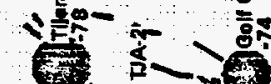

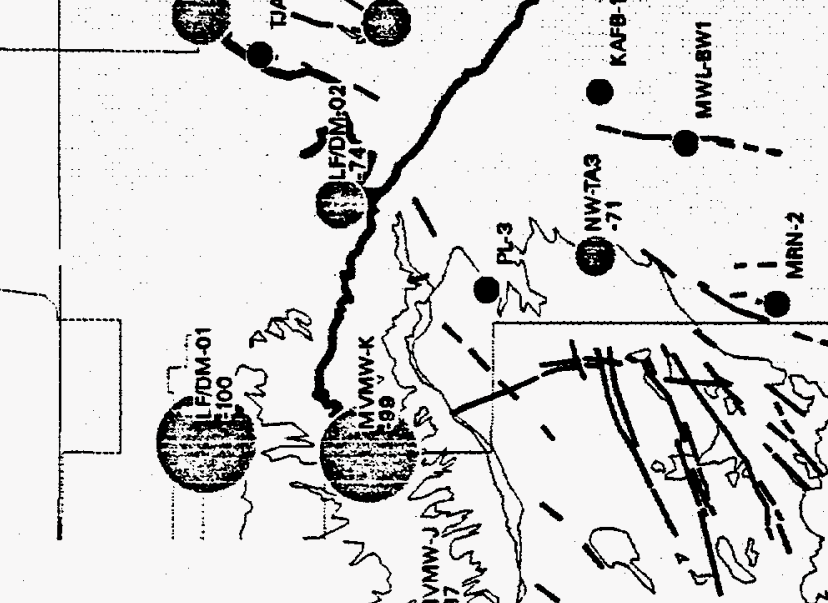

홍

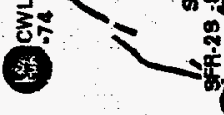

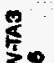
:

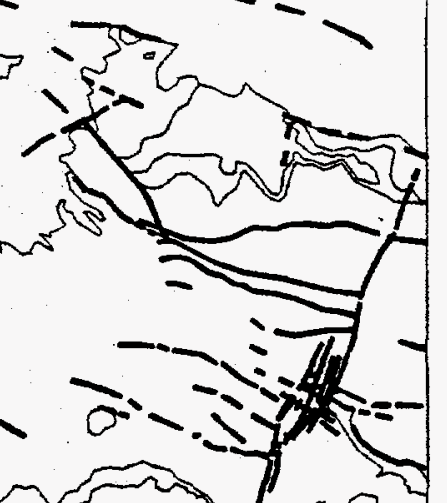

e - $\square \square \square<\gtrless<$
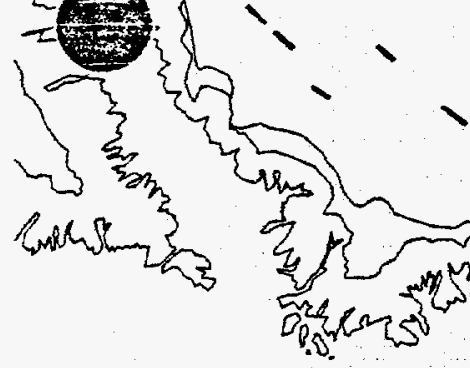

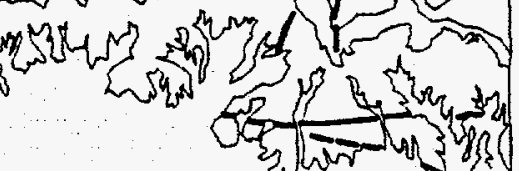




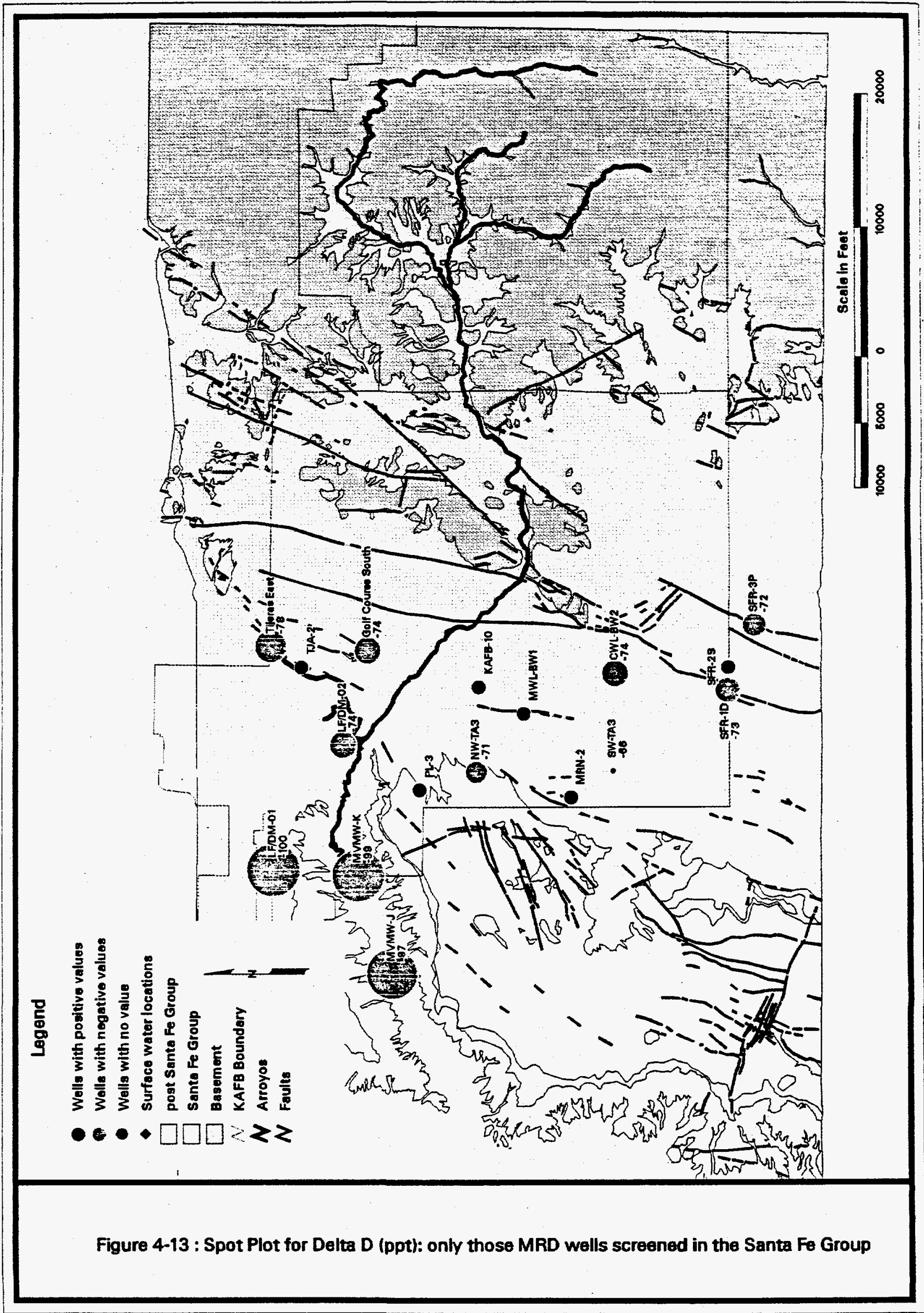


gneiss, greenstone, and limestone are common. Caliche zones occur throughout most of the stratigraphic section. Mafic minerals and dolomitic limestone were noted. This section is dominantly oxidized (as evidenced by red to yellow colors), but reduced zones (occasionally with spots of black organics) are present. Plagioclase and K-feldspar are abundant. Volcanic rock fragments (including glass shards and pumice) are abundant in some strata. Authigenic, pore-filling calcite and clay minerals were observed in thin sections.

\subsubsection{Lower Tertiary}

The lower Tertiary strata are described only in the lithologic log and thin section descriptions for well SFR-3T. At this location, the Lower Tertiary is predominantly green mudstone. Some pyrite and marcasite were observed. One thin section description notes more than 13 percent of the framework grains are volcanic rock fragments. Phyllosilicate cement is abundant; whereas, calcite cement was not documented.

\subsubsection{Yeso Formation}

The Yeso Formation is described only in well SFR-3T. It is composed mostly of siltstone and mudstone with considerable gypsum. Carbonate minerals and anhydrite are present, and limestone beds are observed in outcrops.

\subsubsection{Abo Formation}

The Abo Formation is described only in well TRN-1. It is composed of oxidized (red to brown) sandstone, siltstone, and claystone. Sand grains are quartz, feldspar, mica, schist, and limestone. Some caliche is present.

\subsubsection{Madera Limestone}

The Madera Limestone is dominantly a marine limestone deposit with interbeds of sandstone and conglomerate. Chert is present. Only the EOD Hill well intersects the Madera Limestone; however, it is well exposed in the highlands to the east.

\subsubsection{Precambrian Basement}

The Precambrian Basement is described in the Burn Site well log as mica, schist, and granite. It is exposed in the highland areas where it has been well described. It contains biotite granite, metarhyolite, quartzite, and greenstone. 


\subsection{Sandia/KAFB Groundwater Origins and Flow Paths}

A major goal of this study was to understand the origin (and thus flowpaths) of the Sandia/KAFB groundwaters. The origin of groundwater at various locations are discussed on the basis of the observations presented in Section 4.0 and the modeling methods described in Section 3.0.

\subsection{Groundwater Movement Along Faults: Coyote Springs and EOD Hill}

Groundwater seeps at Coyote Springs and well water at EOD Hill have similar chemistries that are much different than all other groundwater studied at Sandia/KAFB. These two locations are elevated in ionic strength, $\mathrm{Cl}$, total inorganic carbon (TIC), $\mathrm{Na}$, $\mathrm{Ca}, \mathrm{K}$, and $\mathrm{Mg}$ compared with other Sandia/KAFB groundwater (Figure 4-5 and Appendix B). Although Coyote Springs and EOD Hill groundwater are similar to each other when compared with groundwater samples from other Sandia/KAFB wells, they vary from each other markedly in $\mathrm{Ca}$ and $\mathrm{HCO}_{3}$ concentrations (Figure 4-7). Coyote Springs lies on an inferred extension of the northeast-southwest trending fault that passes through EOD Hill well (Figure 4-2).

EOD Hill is oversaturated with $\mathrm{CO}_{2}\left(\mathrm{pCO}_{2}\right.$ greater than $\left.1 \mathrm{~atm}\right)$ and Coyote Springs is slightly undersaturated, as indicated by PHREEQE runs (Table 2-4). Bubbling $\mathrm{CO}_{2}$ gas at Coyote Springs indicates that the groundwater is oversaturated with $\mathrm{CO}_{2}$. The apparent discrepancy at Coyote Springs is probably due to the inability of rising, $\mathrm{CO}_{2}$ exsolving, groundwater to maintain chemical equilibrium. Thus, PHREEQE uses measured parameters to calculate an equilibrium $\mathrm{pCO}_{2}$ slightly less than $1 \mathrm{~atm}$.

Because most of the difference between Coyote Springs and EOD Hill is the $\mathrm{Ca}-\mathrm{HCO}_{3}$ system, it was hypothesized that Coyote Springs is identical to EOD Hill except that it has exsolved more $\mathrm{CO}_{2}$ while precipitating calcite. A mass-balance model shows that Coyote Springs groundwater can be produced from EOD Hill groundwater by exsolving 53 millimoles per liter $(\mathrm{mmol} / \mathrm{L})$ of $\mathrm{CO}_{2}$, and precipitating $13 \mathrm{mmol} / \mathrm{L}$ of calcite, along with small amounts of other reactions (Table 5-1). Because $\mathrm{Cl}$ is considered to be a conservation ion (that is, it does not transfer into solids), the EOD Hill water had to be evaporated by 30 percent to account for the increased $\mathrm{Cl}$ concentration at Coyote Springs. Bromide, another conservative ion, is 17 percent higher in concentration at Coyote Springs than at EOD Hill well, supporting the evaporation concept (the differences between 17 and 30 percent evaporation are probably within analytical error).

This model exactly satisfies all mass-balance constraints; however, it is not necessarily valid thermodynamically. EOD Hill is oversaturated with calcite and $\mathrm{CO}_{2}$, so it is reasonable to expect $\mathrm{CO}_{2}$ exsolution and calcite precipitation. 
Table 5-1. Mass Balance Model for Coyote Springs From EOD Hill

\begin{tabular}{|l|c|}
\hline \multicolumn{1}{|c|}{ Plausible Phase } & Change $(\mathbf{m i n o l} / \mathrm{L})^{\circ}$ \\
\hline $\mathrm{CO}_{2}$ gas & -53.4 \\
\hline Calcite & -12.6 \\
\hline gypsum & -0.6 \\
\hline $\mathrm{Mg} / \mathrm{Na}$ exchange & 22 \\
\hline $\mathrm{K}$-montmorillonite & -1.3 \\
\hline $\mathrm{Ca} / \mathrm{Na}$ exchange & -5.2 \\
\hline Evaporation factor & $30 \%$ \\
\hline
\end{tabular}

an +" indicates phase is added to the water (for exchange reactions, the first element is added and the second is removed from solution); "-" indicates phase is removed from the water.

Using PHREEQE, a reaction-path model was developed to portray the chemical evolution of EOD Hill groundwater as $\mathrm{CO}_{2}$ is exsolved (Figure 5-1). As $\mathrm{CO}_{2}$ exsolves from EOD Hill groundwater, calcite precipitates and both $\mathrm{Ca}$ and $\mathrm{HCO}_{3}$ contents decreased (left-hand column of Figure 5-1). Coyote Springs groundwater compares favorable to EOD Hill groundwater after exsolving about 10 to $20 \mathrm{mmol}$ of $\mathrm{CO}_{2}$ (righthand column of Figure 5-1). Coyote Springs groundwater is shown at its measured $\mathrm{pH}$ of 6.15 and a pH of 6.50 to show the sensitivity of $\mathrm{HCO}_{3}$ to $\mathrm{pH}$. The relatively small differences in $\mathrm{Na}, \mathrm{K}, \mathrm{Mg}, \mathrm{SO}_{4}$, and $\mathrm{Cl}$ are explained by sampling and analytical uncertainties, as seen in the variations between samplings (Appendix A).

As $\mathrm{CO}_{2}$-charged $\left(\mathrm{CO}_{2}\right.$ greater than $\left.1 \mathrm{~atm}\right)$ groundwater rises along the fault at Coyote Springs, the hydrostatic pressure decreases and $\mathrm{CO}_{2}$ exsolves. The modeling presented here indicates that the ancestral water could be identical to the water sampled at EOD Hill; or EOD Hill and Coyote Springs groundwaters could be evolved products from a common ancestral water body. That these two groundwaters both have anomalous concentrations of many salts and occur adjacent to basin faults, together with the geochemical models, suggests that deep groundwater is upwelling along these faults. The ultimate source of this groundwater cannot be determined from these data. The higher salinities suggest a component of deep formation fluid.

By starting with EOD Hill groundwater composition and progressively exsolving $\mathrm{CO}_{2}$, it is shown that a thermodynamically valid path exists to obtain Coyote Springs groundwater. Mineral saturation indices (SIs) are monitored along the reaction path to check that no violations exist (for example, the failure to allow a mineral to precipitate). SIs for the reaction-path model are shown in Figure 5-2. The first reaction step has a sharper change because it includes the equilibration of EOD Hill groundwater with calcite (it was initially oversaturated). As $\mathrm{CO}_{2}$ is exsolved, $\mathrm{pCO}_{2}$ drops; after about $400 \mathrm{mg} / \mathrm{L}$ of $\mathrm{CO}_{2}$, it is below $1 \mathrm{~atm}$. $\mathrm{CO}_{2}$ would continue to leave the groundwater at this stage due to diffusion because atmospheric $\mathrm{pCO}_{2}$ is much lower (about $10^{-3.5}$ atm); 

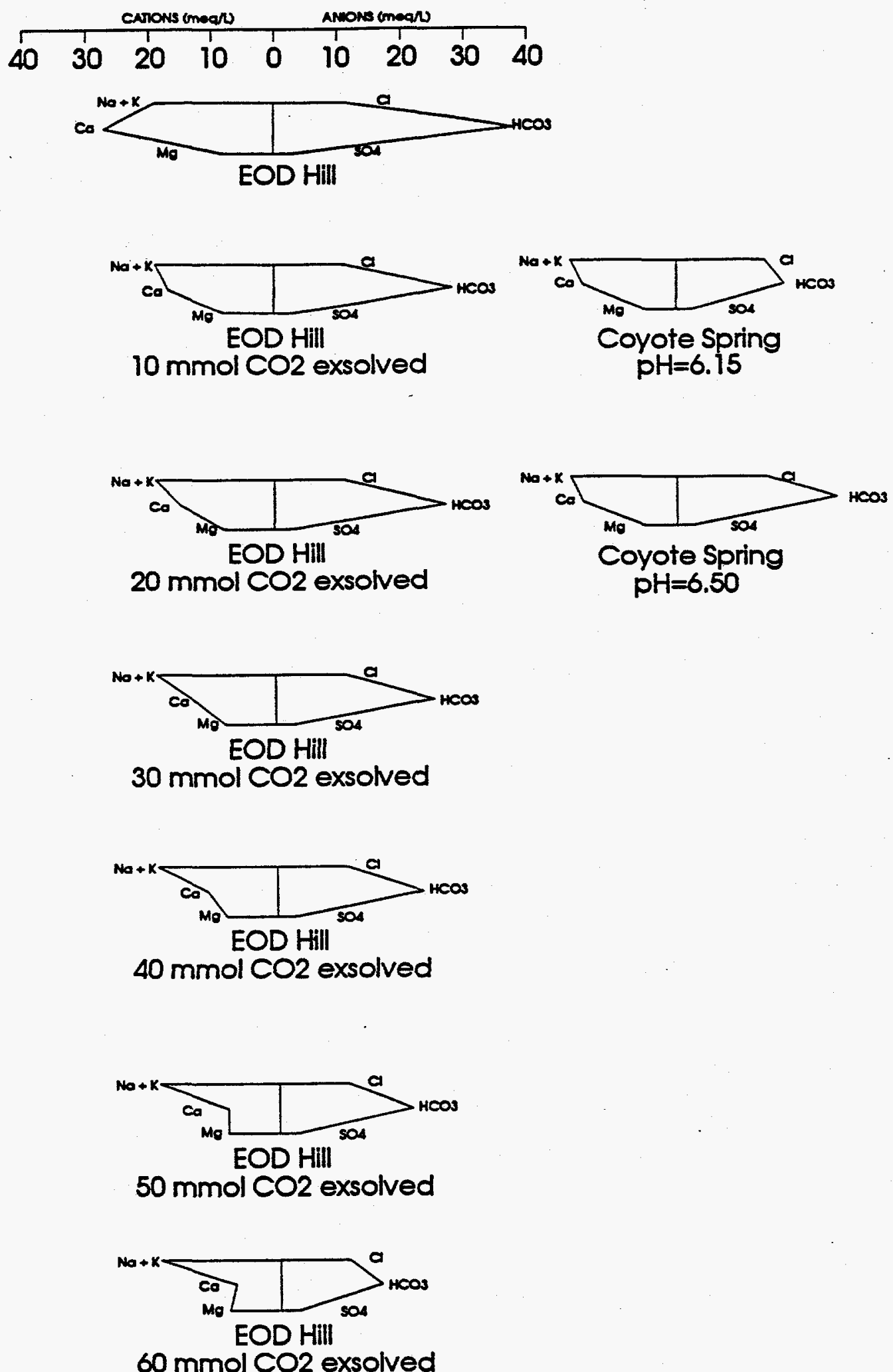

Figure 5-1. Stiff Diagrams Showing Reaction Paths as $\mathrm{CO}_{2}$ Exsolves from EOD Hill Water and Comparison to Coyote Springs at its Measured pH (6.15) and at pH 6.50 


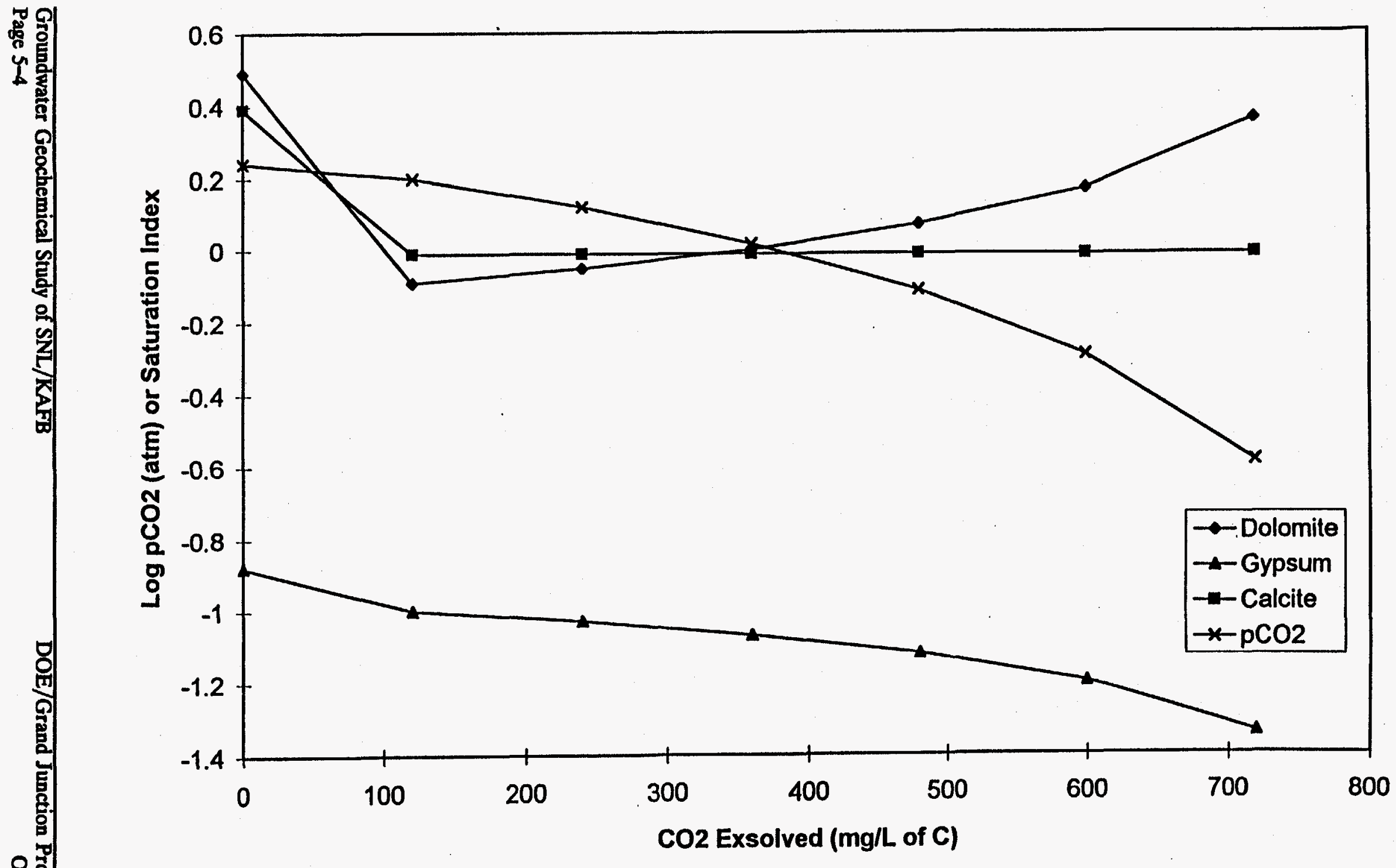

Figure 5-2. Mineral Saturation Indices and $\mathrm{CO}_{2}$ Partial Pressures During Exsolution of $\mathrm{CO}_{2}$ from EOD Hill Water 
however, the rate would be slower. Gypsum is undersaturated throughout the simulation and would not precipitate. Dolomite becomes undersaturated after the first reaction step and then becomes oversaturated as the reaction proceeds. At the low temperatures of these groundwaters, dolomite is not likely to precipitate and, thus, does not violate thermodynamic constraints. Calcite stays at saturation throughout the simulation as a condition of the model.

Besides having anomalously high concentrations of most major ions, EOD Hill and Coyote Springs also have depleted signatures for $\delta^{18} \mathrm{O}$ and $\delta \mathrm{D}$. These chemical distinctions from surrounding wells suggest that the groundwater at EOD Hill/Coyote Springs has a different source. The chemical model presented above suggests that EOD Hill and Coyote Springs groundwater are from the same source; most of the chemical variation between them can be explained by $\mathrm{CO}_{2}$ releases at Coyote Springs.

The difference in $\mathrm{Cl}$ concentration between EOD Hill and Coyote Springs is explained by evaporation at Coyote Springs; the $\delta \mathrm{D}$ variation can also be explained by evaporation of a similar magnitude. On a plot that compares $\delta \mathrm{D}$ values with $\delta^{18} \mathrm{O}$ values, Coyote Springs groundwater lies on a line of slope 6 from EOD Hill groundwater (Figure 4-11). If evaporation followed a simple Rayleigh distillation, evaporated waters would lie on the MWL with a slope of 8. Data from naturally evaporated waters and experimental evidence indicate, however, that evaporated water becomes heavier in $\delta^{18} \mathrm{O}$ relative to $\delta \mathrm{D}$; slopes range from about 4 to 6 (Craig et al. 1963). The slope of 6 for the Coyote Springs groundwater is in agreement with this range, suggesting that evaporation of about 20 percent could account for the $\delta \mathrm{D}-\delta^{18} \mathrm{O}$ evolution from EOD Hill groundwater. Evaporation could occur in the pool from which Coyote Springs is sampled, perhaps enhanced by the effervescing $\mathrm{CO}_{2}$ gas.

Groundwater sampled from two shallow alluvial wells (Greystone and Schoolhouse) near EOD Hill/Coyote Springs both have $\delta D$ values of $-73 \%$ (Figure 4-12). Sol se Mete Spring farther to the east has a $\delta \mathrm{D}$ value of $-78 \%$. These values are all within the range (-70 to $-83 \%$ ) depicted by Yapp (1985) for recharge from Sandia/NM and Manzano Mountains and suggests that these groundwaters represent shallow infiltration. The $\delta \mathrm{D}$ of rainfall is dependent on latitude, climate (temperature and amount of precipitation), and elevation (Dansgaard 1964). Elevation should increase the $\delta \mathrm{D}$ value; however, the value for Sol se Mete Spring suggests that elevation within the project area has a minimal effect.

EOD Hill and Coyote Springs have $\delta \mathrm{D}$ values $(-100$ and $-87 \%$ ) which are significantly depleted and, thus, are unlikely to be related to infiltration. The $\delta \mathrm{D}$ values coupled with the more saline chemistry suggests that these two groundwaters originate at depth. Chemical and isotopic data from deep basins are limited; however, it is useful to speculate on possible origins of a $\delta D$ depleted deep water source.

Yapp (1985) identified depleted $\delta \mathrm{D}$ signatures in the deeper horizons of the Santa Fe Group in the Albuquqerque Basin and proposed that this was old water that had been 
introduced from the Rio Grande River during a time when climatic differences produces $\delta \mathrm{D}$ depleted precipitation. It is common for $\delta \mathrm{D}$ and salinity to increase with depth in a basin. A well-studied example is the Milk River aquifer in Alberta, Canada. The $\delta \mathrm{D}$ data from this aquifer show a distinct trend of $\delta \mathrm{D}$ depletion with depth. The cause of the $\delta \mathrm{D}$ depletion is controversial, having been explained by dispersive mixing with connate water (Schwartz and Muehlenbachs 1979), membrane filtration (Phillips et al 1986), and diffusion from shales (Hendry and Schwartz 1988).

These observations suggest that it is reasonable to expect depleted $\delta \mathrm{D}$ values in deeper basin groundwaters.

\subsection{Midbasin Santa Fe Group Groundwater (CWL-BW2 and MWL-BW1)}

Chloride concentrations in the Santa Fe Group groundwater appear to decrease westerly away from the basin boundary faults (Figure 4-6 and Figure 4-2). Other dissolved ions (Na, Ca, TIC, Br, and F) also appear to show this spatial distribution (Appendix B). These distributions suggest that high-salinity groundwater such as that present at EOD Hill may be entering the basin near the eastern basin boundary.

Examination of the major ion chemistry indicates that with the exception of TIC, dissolved major ions in CWL-BW2 are consistent with dilution factors between 2 and 6, and almost all are 3 to 4 (Table 5-2). A mass-balance model using NETPATH shows the extent of gas and mineral phase reactions required if EOD Hill groundwater is mixed with pure water to produce CWL-BW2 groundwater (Table 5-3). A relatively large dilution (67-percent pure water) is required and a large amount of $\mathrm{CO}_{2}$ gas must be lost. The dilution will be larger if the dilute water were not pure water, but rather had some ions in it.

Models such as these do not identify the source of the dilute (pure) water. Dilute water may come from vertical infiltration or recharge from Coyote arroyo. If groundwater at MVMW-K (a well drilled on the Tijeras arroyo) is used to simulate the dilute groundwater, the results are similar to using pure water (Table 5-3).

CWL-BW2 is the closest well to the basin boundary. Unfortunately, this well is screened over a much thicker and deeper interval (490-980 feet) than other Santa Fe Group wells except KAFB-10. It is possible that the CWL-BW2 groundwater signature is influenced by deeper saline horizons. MWL-BW1 (also completed in the Santa Fe Group) samples are shallower (452-472 feet) and are more dilute than CWL-BW2 (see the ionic strength spot plot in Appendix B). MWL-BW1 is farther out in the basin than CWL-BW2, and flow directions (Figure 4-3) indicate that this area is influenced by groundwater flowing westerly. Mass-balance models for the evolution of MWL-BW1 both from CWL-BW2 and from EOD Hill groundwater are in Table 5-4. Both models indicate a high degree of dilution to obtain the relatively low ionic concentrations at 
MWL-BW1. As with the previous models, use of a dilute groundwater such as MVMW-K instead of pure water would not significantly change the model results.

Table 5-2. Comparison of EOD Hill and CWLBW2 Groundwater Chemistries

\begin{tabular}{|c|c|c|c|}
\hline Component & EOD Hi1 & CWL-BWZ & Dllution Factor \\
\hline $\mathrm{Ca}$ & 540 & 130 & 4 \\
\hline $\mathbf{N a}$ & 410 & 87 & 5 \\
\hline $\mathbf{K}$ & 38 & 7 & 6 \\
\hline $\mathbf{M g}$ & 100 & 30 & 3 \\
\hline Cl & 390 & 130 & 3 \\
\hline So, & 140 & 77 & 2 \\
\hline TIC & 1175 & 114 & 10 \\
\hline Ionic Strength & 0.067 & 0.017 & 4 \\
\hline pH & 6.07 & 6.85 & - \\
\hline
\end{tabular}

Table 5-3. NETPATH Models: Mixing of EOD Hill Groundwater with Dilute Water (pure water or MVMW-K groundwater) to Produce CWL-BW2 Groundwater

\begin{tabular}{|c|c|c|}
\hline \multirow[b]{2}{*}{ Plausible Phases } & \multicolumn{2}{|c|}{ Mass Transier? } \\
\hline & $\begin{array}{l}\text { Pure Water } \\
(\text { mmol/L) }\end{array}$ & $\begin{array}{l}\text { MVMW-K } \\
\text { Groundwater } \\
(\text { mmol/L) }\end{array}$ \\
\hline $\mathrm{CO}_{2}$ gas & -275 & -25.2 \\
\hline Calcite & -2.8 & -3.5 \\
\hline Gypsum & +0.3 & +0.1 \\
\hline K-montmorillonite & -0.5 & -0.5 \\
\hline $\mathrm{Na} / \mathrm{Ca}$ exchange & +1.2 & +15 \\
\hline $\mathrm{Mg} / \mathrm{Na}$ exchange & +0.1 & +0.2 \\
\hline Percent of dilute water & $67 \%$ & $69 \%$ \\
\hline Percent of EOD water & $33 \%$ & $31 \%$ \\
\hline
\end{tabular}

" + " indicates phase is added to the water (for exchange reactions, the first element is added and the second is removed from solution); "-" indicates phase is removed from the water. 
Table 5-4. NETPATH Models: Mixing of EOD Hill or CWL-BW/2 Groundwater with Pure Water to Produce MWL-BW1 Groundwater

\begin{tabular}{|c|c|c|}
\hline \multirow[b]{2}{*}{ Plausible Prases } & \multicolumn{2}{|c|}{ Mass Transfer: } \\
\hline & (mOD Fin & $\begin{array}{l}\text { CWLBW2 } \\
(\mathrm{mma} / \mathrm{h})\end{array}$ \\
\hline $\mathrm{CO}_{2}$ gas & -6.7 & -1.3 \\
\hline Calcite & +1.4 & +1.9 \\
\hline Gypsum & +0.3 & +03 \\
\hline K-montmorillonite & +0.1 & +0.2 \\
\hline $\mathrm{Ca} / \mathrm{Na}$ exchange & +12 & +1.4 \\
\hline $\mathrm{Mg} / \mathrm{Na}$ exchange & -0.6 & -0.6 \\
\hline $\begin{array}{l}\text { Percent of EOD or } \\
\text { CWL-BW2 }\end{array}$ & $7 \%$ & $20 \%$ \\
\hline Percent of pure water & $93 \%$ & $80 \%$ \\
\hline
\end{tabular}

"n +" indicates phase is added to the water (for exchange reactions, the first element is added and the second is removed from solution); "-" indicates phase is removed from the water.

These results indicate that a small contribution of groundwater in the Santa Fe Group may have come from saline fluids migrating along the basin boundary faults. This saline fluid is a minor component, however, compared to a more dilute fluid that dominates the Santa Fe Group groundwater system. Geochemical data are insufficient to determine the exact origin (arroyo infiltration, inter-arroyo infiltration, Rio Grande, or low-salinity mountain discharge) of this dilute fluid. Recent measurements by Sandia/NM indicate that arroyo recharge is about $1 / 3$ or less of mountain-front recharge.

\subsection{Groundwater at South Fence Road Wells}

\subsubsection{Santa Fe Group Groundwater Chemistry}

The similarity of Santa Fe Group groundwater chemistry between wells SFR-1, SFR-2, and SFR-3P indicates a common origin (Figure 4-9). Elevated $\mathrm{Cl}$ concentrations relative to other Santa Fe Group wells (Figure 4-6) suggest an influence from the high-salinity fluids moving along the basin faults. The amount of dilution required to produce SFR-3P groundwater from EOD Hill (used to simulate the high-salinity, faultrelated fluid) groundwater is presented in Table 5-5.

The $\mathrm{Ca}, \mathrm{Na}, \mathrm{Mg}$, and $\mathrm{Cl}$ in SFR-3P could be the result of mixing of a saline fluid, such as EOD Hill groundwater, with a dilute fluid with dilution factors of 3 to 5. The lower dilution factor for $\mathrm{SO}_{4}$ suggests an influx of $\mathrm{SO}_{4}$ from the high-SO 4 groundwaters observed in SFR-3T and SFR-4T. The high TIC dilution factor suggests $\mathrm{CO}_{2}$ exsolution or calcite precipitation. 


\section{Table 5-5. Dilution Factors for Major Ions to Produce SFR-3P From EOD Hill Groundwater}

\begin{tabular}{|c|c|c|c|}
\hline Conponerl & 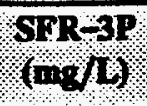 & $(\mathrm{mob})$ & Ellution \\
\hline $\mathrm{Ca}$ & 120 & 540 & 5 \\
\hline $\mathbf{N a}$ & 87 & 410 & 5 \\
\hline $\mathbf{K}$ & 4.6 & 38 & 8 \\
\hline $\mathbf{M g}$ & 28 & 100 & 4 \\
\hline TIC & 100 & 1175 & 12 \\
\hline $\mathrm{SO}_{4}$ & 94 & 140 & 2 \\
\hline $\mathrm{Cl}$ & 140 & 390 & 3 \\
\hline$\overline{\mathrm{pH}}$ & 6.85 & 6.07 & \\
\hline
\end{tabular}

EOD divided by SFR-3P.

NETPATH was used to examine the results of mixing three different types of groundwater (EOD Hill, SFR-3T, and pure water) to produce the groundwater composition of SFR-3P (Table 5-6).

Table 5-6. NETPATH Results of Mixing Groundwater from EOD Hill, SFR-3T, and Pure Water to Produce SFR-3P Groundwater

\begin{tabular}{|c|c|}
\hline Plausible Phase & Mass Transfer $^{(\mathrm{mmol} / \mathrm{h})^{\prime}}$ \\
\hline $\mathrm{CO}_{2}$ gas & -28.9 \\
\hline Calcite & -3.9 \\
\hline Gypsum & +0.0 \\
\hline K-montmorillonite & -0.7 \\
\hline $\mathrm{Mg} / \mathrm{Na}$ exchange & +0.3 \\
\hline $\mathrm{Na} / \mathrm{Ca}$ exchange & +1.8 \\
\hline Water Type & Amount \% \\
\hline EOD Hill & +36 \\
\hline SFR-3T & +2 \\
\hline Pure Water & +62 \\
\hline
\end{tabular}

" + " indicates phase is added to the water (for exchange reactions, the first element is added and the second is removed from solution); "-" indicates phase is removed from the water. 
This model indicates that SFR-3P groundwater can be produced from 62-percent dilute water (simulated by pure water), 36-percent EOD Hill water (simulating the saline fault-related water), and 2-percent SFR-3T (simulating high-SO ${ }_{4}$ water from the footwall of the fault). The dominant reaction is the release of TIC via $\mathrm{CO}_{2}$. As with the previous models that simulate the Santa Fe Group waters, a dilute groundwater is required. This dilute groundwater is likely to have its origin from infiltration of precipitation. Geochemical data are not sufficient to determine if this water infiltrates in the arroyos or the inter-arroyo areas.

\subsubsection{Lower Tertiary Groundwater in the Footwall}

Two wells (SFR-3T and SFR-4T) are screened in the Lower Tertiary unit along South Fence Road. The groundwater compositions of these two wells suggest that groundwater initially saturated with gypsum has migrated through the Lower Tertiary unit and exchanged $\mathrm{Ca}$ for $\mathrm{Na}$. SFR-3T and SFR-4T have nearly equivalent $\mathrm{SO}_{4}$ concentrations; however, SFR-4T has a higher concentration of Na relative to $\mathrm{Ca}$ (Table 5-7). The SI for gypsum $(-0.049)$ in the SFR-3T well indicates the presence of gypsum; however, well SFR-4T is significantly undersaturated $(\mathrm{SI}=-0.956$ ) with gypsum (Table $2-4)$. If groundwater similar to SFR-3T contacts Na-rich exchangeable clay minerals, $\mathrm{Ca}$ will exchange with $\mathrm{Na}$ and produce a composition similar to that observed in SFR-4T.

Table 5-7. Composition of SFR-3T Before and After Computed Reactions Compared to SFR-AT

\begin{tabular}{|c|c|c|c|}
\hline \multirow[t]{2}{*}{ Component } & \multicolumn{3}{|c|}{$\operatorname{mmo1} / \mathrm{L}$} \\
\hline & $S F R-3 T$ & $\begin{array}{l}\text { SFR } 3 T \\
\text { Atter Reaction' }\end{array}$ & $\mathrm{SFR}-\mathrm{TT}$ \\
\hline $\mathrm{Ca}$ & 11.26 & 2.70 & 1.43 \\
\hline $\mathrm{Na}$ & 21.82 & 50.74 & 52.38 \\
\hline$\overline{\mathbf{K}}$ & 0.14 & 0.06 & 0.06 \\
\hline $\mathbf{M g}$ & 1.69 & 0.14 & 0.14 \\
\hline $\mathrm{Cl}$ & 1.33 & 5.07 & 5.09 \\
\hline $\mathrm{HCO}_{3}$ & 0.34 & 5.51 & 2.30 \\
\hline $\mathrm{SO}_{4}$ & 22.98 & 22.98 & 19.85 \\
\hline$\overline{\mathrm{pH}}$ & 7.45 & 7.43 & 757 \\
\hline
\end{tabular}

Calculated water composition after reacting $11 \mathrm{mmol} / \mathrm{L}$ of the reaction: (in mmol/L) -1.000 $\mathrm{Ca}, 2.629 \mathrm{Na},-0.141 \mathrm{Mg},-0.007 \mathrm{~K}$, and $0.340 \mathrm{Cl}$. Calculation includes the equilibration with calcite and $\mathrm{pCO}_{2}=10^{-200} \mathrm{~atm}$.

A NETPATH calculation supports the concept that $\mathrm{Ca}$ has exchanged for $\mathrm{Na}$ to form SFR-4T groundwater from SFR-3T groundwater (Table 5-8). In the model, $\mathrm{Ca} / \mathrm{Na}$ exchange is the dominant factor. Moderate amounts of calcite and halite dissolution, gypsum precipitation, $\mathrm{CO}_{2}$ loss, and $\mathrm{Mg} / \mathrm{Na}$ exchange are also required. 


\section{Table 5-8. NETPATH Model To Produce SFR-4T from SFR-3T Groundwater}

\begin{tabular}{|c|c|}
\hline Plausible Phase & $\begin{array}{l}\text { Mass Transter } \\
(\mathrm{mmol} / \mathrm{C})\end{array}$ \\
\hline $\mathrm{CO}_{2}$ gas & -3.2 \\
\hline Calcite & +5.1 \\
\hline Gypsum & -3.1 \\
\hline Halite & +3.8 \\
\hline K-montmorillonite & -0.22 \\
\hline $\mathrm{Mg} / \mathrm{Na}$ exchange & +1.55 \\
\hline $\mathrm{Ca} / \mathrm{Na}$ exchange & +11.85 \\
\hline
\end{tabular}

an + " indicates phase is added to the water (for exchange reactions, the first element is added and the second is removed from solution); "-" indicates phase is removed from the water.

The results of the NETPATH model were used to formulate a reaction-path model. In this model, $\mathrm{Ca}, \mathrm{Mg}$, and $\mathrm{K}$ are exchanged for $\mathrm{Na}$, and $\mathrm{Cl}$ is balanced by the addition of halite. This "reaction" $(-1.000 \mathrm{Ca},-0.141 \mathrm{Mg},-0.007 \mathrm{~K}, 0.340 \mathrm{Cl}$, and $2.629 \mathrm{Na}$; in $\mathrm{mmol} / \mathrm{L}$ ) is added in steps to the SFR-3T water while maintaining equilibrium with calcite and $\mathrm{pCO}_{2}$ of $10^{-2.0} \mathrm{~atm}$. The cation ratios were determined by examining the NETPATH results (Table 5-8). The $\mathrm{pCO}_{2}$ of $10^{-2.0}$ atm is a reasonable value for a subsurface environment and is consistent with many of the values for the Sandia/KAFB site (Table 2-4).

The reaction was added in steps up to $11.0 \mathrm{mmol} / \mathrm{L}$. The results of adding $1.8,5.5$, and 11.0 mmols of reaction are shown as Stiff diagrams in Figure 5-3, and the results of the $11.0 \mathrm{mmol}$ step are listed in Table 5-7. The results of the $11 \mathrm{mmol}$ step are a reasonable match to the SFR-4T composition (Figure 5-3 and Table 5-7). The pH of the simulation is 7.43 which also compares favorably with the $\mathrm{pH}$ of 7.57 measured in SFR-4T.

Saturation indices for common minerals are shown as a function of reaction progress in Figure 5-4. Calcite remains at saturation as a condition of the model. Since gypsum was only slightly oversaturated in SFR-3T, it was allowed to start out oversaturated. Gypsum equilibrium was not set as a condition in the model because gypsum was observed only in the area of the initial solution (Yeso Formation or in the fault) and not in the Lower Tertiary unit. All other minerals were undersaturated throughout the simulation. 


\begin{tabular}{llllllllllllll}
\hline 10 & 50 & 40 & 30 & 20 & 10 & 0 & 10 & 20 & 30 & 40 & 50 & 60
\end{tabular}
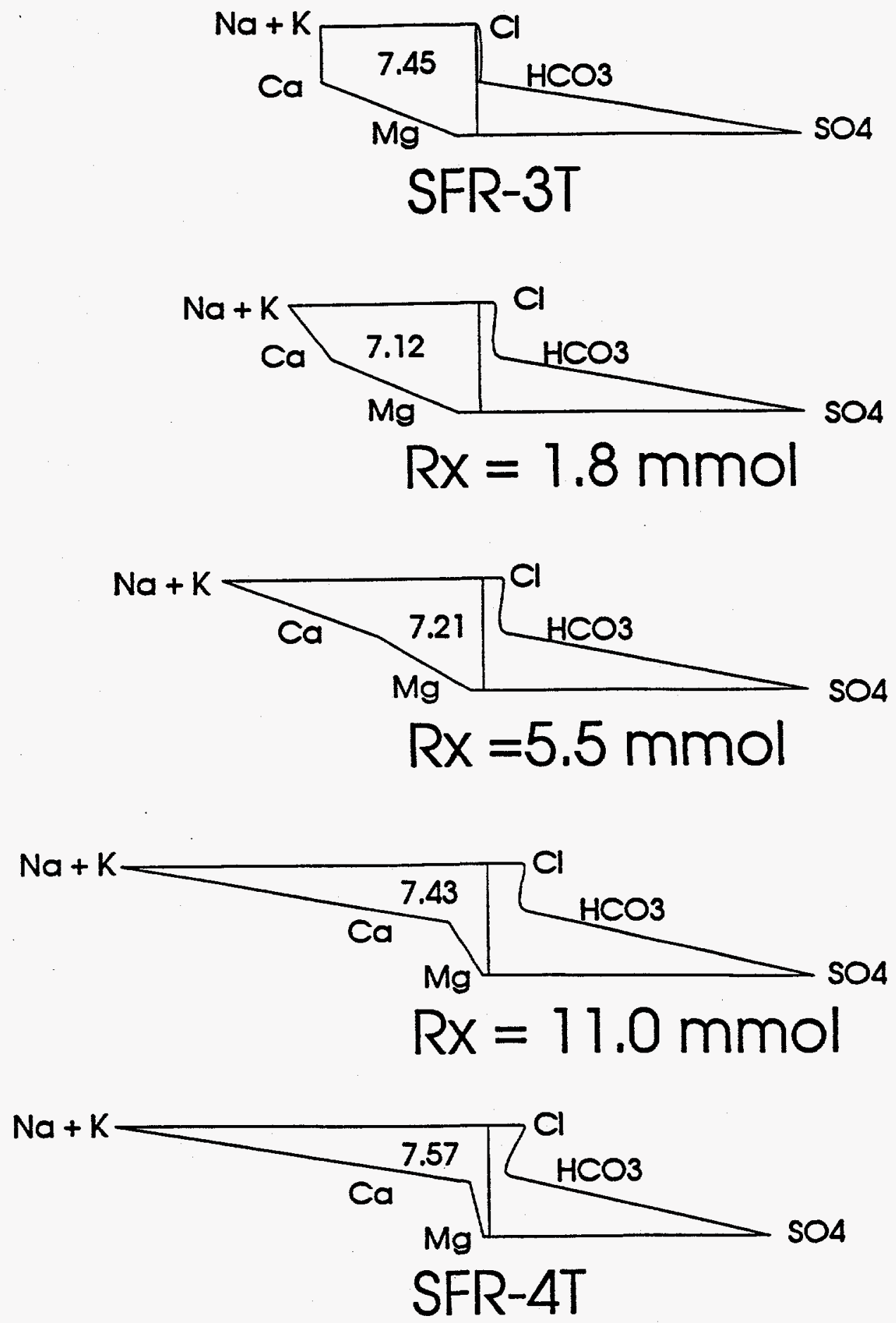

Figure 5-3. Stiff Diagrams Showing the Chemical Evolution of SFR-3T Groundwater as $1.8,5.5$, and $11.0 \mathrm{mmol}$ of a Reaction are Added, Compared to SFR-4T 


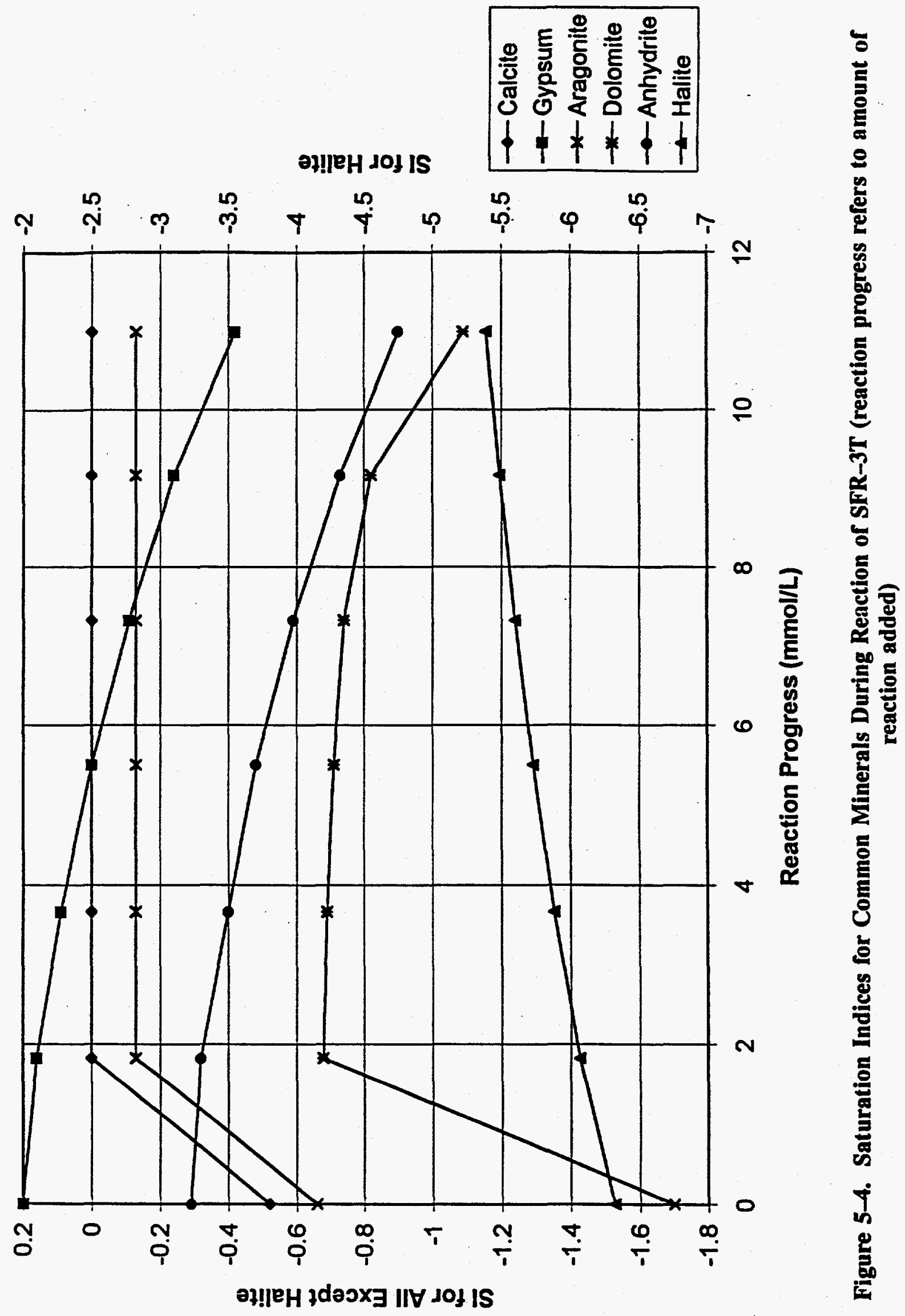


Note that the reaction-path model simulates all the cations by cation-exchange reactions whereas the NETPATH simulation used precipitation of K-montmorillonite to account for the $\mathrm{K}$ loss. Either of these clay mineral reactions is permissible given the lack of any data on the clay mineral composition of the subsurface. The Lower Tertiary unit is composed largely of mudstone and siltstone which is likely to contain abundant exchangeable clay minerals.

In summary, the reaction-path model shows that if SFR-3T groundwater were to flow through a reactive zone containing calcite, Na-rich exchangeable clays, and a small amount of halite, a groundwater similar in composition to SFR-4T would evolve (Figure 5-5).

\subsection{Groundwater in the Tijeras Arroyo Area}

The NPN anomaly at over 400 feet beneath the Tijeras Arroyo Golf Course (Figure 4-10) suggests vertically downward infiltration. Fertilizers applied to the golf course are a common source of nitrogen. The heavy irrigation (equivalent to about 48 inches per year) and standing water greatly enhance infiltration. The composition of the groundwater in the Golf Course South well is likely a reflection of the composition of the irrigation water after it has reacted with the Santa Fe Group aquifer.

The anomalously high cation/anion charge imbalance (Table 2-4) in groundwater from the Golf Course South well suggests that a major anion was not included in the chemical analyses. If the missing anion were phosphate or an organic anion common to fertilizer, this would support the concept of vertical migration to depths of more than 400 feet.

A NETPATH model indicates that the composition of Golf Course South well groundwater will be produced if pure water were to dissolve small amounts of calcite, gypsum, and halite along with some $\mathrm{CO}_{2}$ release and cation exchanges. The $\mathrm{Cl}$ in the water more likely results from the initial composition (perhaps with some evaporation) of the irrigation water rather than from the dissolution of halite. The model assumes that the irrigation water is dilute (pure water). Therefore, the chemical reactions presented in Table 5-9 can be considered maximums. All the mass transfer in Table 5-9 is relatively minor (and would decrease if significant dissolved ions were in the initial water) and, thus, the model provides one reasonable explanation for the origin of the Golf Course South groundwater. 


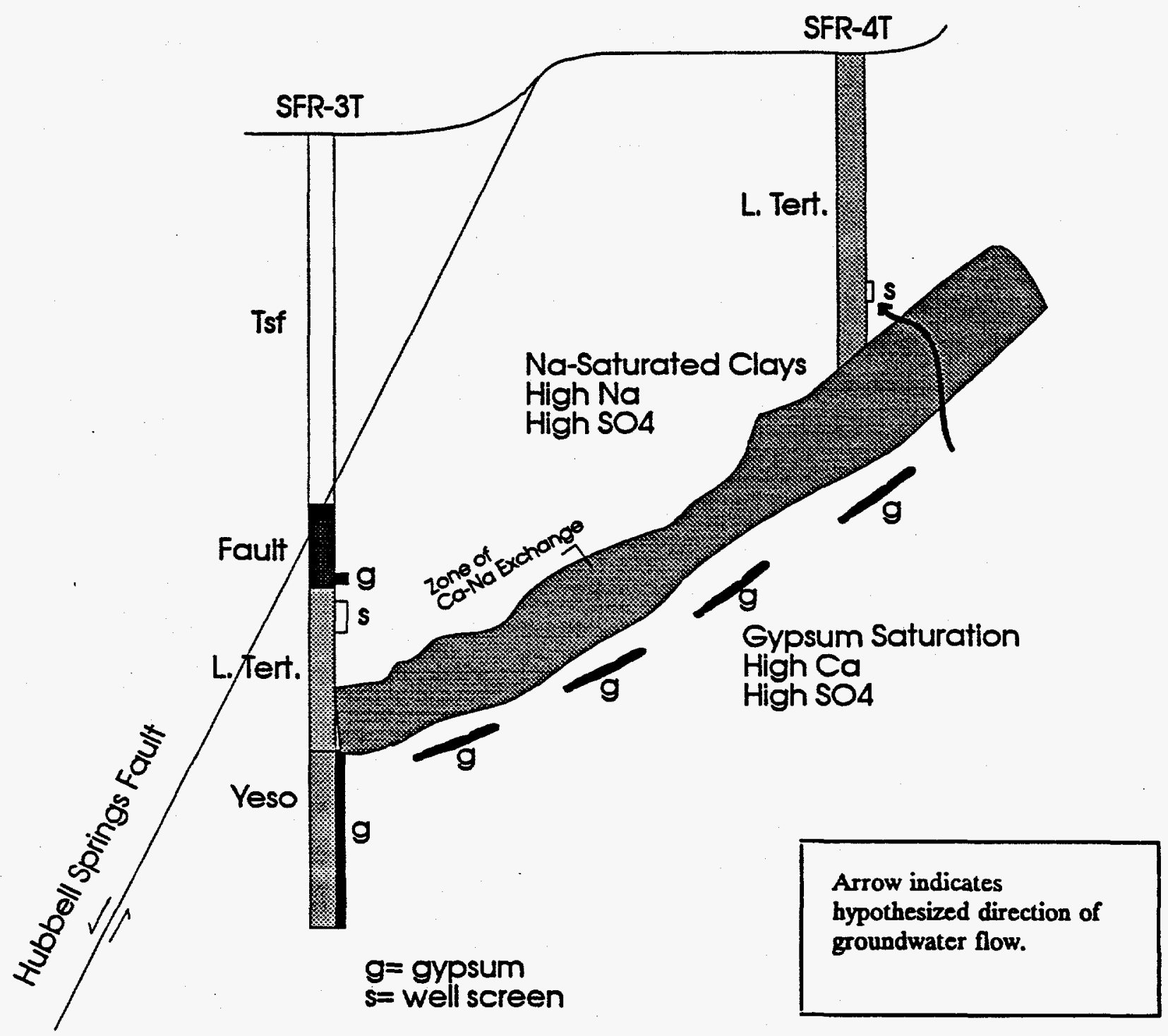

Figure 5-5. Schematic Diagram Showing Origin of SFR-4T Water from SFR-3T Water (High SO, High $\mathrm{Ca}$ ) 


\section{Table 5-9. NETPATH Calculated Chemical Interactions to Produce Golf Course South Groundwater from Pure Water}

\begin{tabular}{|c|c|}
\hline (6. & Mass Transfer \\
\hline $\mathrm{CO}_{2}$ gas & -1.42 \\
\hline Calcite & +1.95 \\
\hline Gypsum & +0.68 \\
\hline K-montmorillonite & +0.19 \\
\hline $\mathrm{Na} / \mathrm{Mg}$ exchange & -0.70 \\
\hline $\mathrm{Ca} / \mathrm{Na}$ exchange & +0.48 \\
\hline halite $(\mathrm{NaCl})$ & +1.35 \\
\hline
\end{tabular}

" + " indicates phase is added to the water (for exchange reactions, the first element is added and the second is removed from solution); "-" indicates phase is removed from the water. 


\subsection{Conclusions and Recommendations}

Mass-balance and reaction-path models were used to help understand the chemical evolution of groundwater at the Sandia/KAFB site. The geochemical models showed that the geochemistry of the groundwater is consistent with existing conceptual models of groundwater flow. Because the chemistry of the solid components is not completely known, the geochemical models have few constraints and, thus, multiple models are possible.

Spatial relationships of major ions in groundwater at the Sandia/KAFB site offer insight into the origin of the groundwater. In the Santa $\mathrm{Fe} \mathrm{Group}, \mathrm{Cl}$ and other ion concentrations decrease away from the basin-boundary faults to the western portion of the basin. Higher concentrations of $\mathrm{Cl}$ and other ions are found in groundwater directly associated with the faults (EOD Hill and Coyote Springs). The chemical signature of the fault-related groundwater suggests a deep origin.

Mass-balance models were developed that are consistent with mixing of the high-salinity, fault-related groundwater with a dilute groundwater to produce the Santa Fe Group groundwater near the boundary faults. About 33-percent high-salinity fluid was required. The origin of the dilute groundwater is not constrained by existing geochemical data.

Some of the groundwater in the footwall near South Fence Road is high in $\mathrm{Ca}$ and $\mathrm{SO}_{4}$ due to equilibration with gypsum. This water has exchanged $\mathrm{Ca}$ for $\mathrm{Na}$ as it migrated through Na-rich clays, resulting in a Na-SO ${ }_{4}$ enriched groundwater. This $\mathrm{Na}-\mathrm{SO}_{4}$ water makes up less than 2 percent of the Santa Fe Group groundwater in the South Fence Road wells.

To gather enough geochemical information on the subsurface to produce a reasonably unique model capable of defining groundwater flow paths and recharge areas would be a monumental task. It is recommended that resources would be better spent drilling additional wells for geohydrologic testing and using environmental tracers $\left(\right.$ e.g., ${ }^{3} \mathrm{H},{ }^{36} \mathrm{Cl}$, $\mathrm{Br},{ }^{14} \mathrm{C}$ ) to obtain information on groundwater flow. Artificially induced tracers could be used in areas where high flow rates are expected. 


\subsection{References}

Anderholm, S.K., 1988. "Ground-Water Geochemistry of the Albuquerque Basin, Central New Mexico," U.S. Geol Survey Water-Resources Investigations Report, 86-4094.

Craig, H., 1961. "Isotopic Variations in Meteoric Waters," Science, Vol. 133, pp. 1702-1703.

Craig H., LI. Gordon, and Y. Horibe, 1963. "Isotopic Exchange Effects in the Evaporation of Water," Jour. Geophys. Research, Vol. 68.

Dansgaard, W., 1964. "Stable Isotopes in Precipitation," Tellus, Vol. 16, pp. 436-468.

Garrels, R.M., and F.T. MacKenzie, 1967. "Origin of the Chemical Composition of Some Springs and Lakes in Equilibrium Concepts in Natural Water Systems," Amer. Chem. Soc. Adv. Chem. Ser., No. 67, pp. 222-242.

Helgeson, H.C., 1968. "Evaluation of Irreversible Reactions in Geochemical Processes Involving Minerals and Aqueous Solutions-I. Thermodynamic Relations," Geochemical et Cosmochemical Acta, Vol. 32, pp. 853-877.

Hendry, M.J. and F.W. Schwartz, 1988. "An Alternative View on the Origin of Chemical and Isotopic Patterns in Groundwater from the Milk River Aquifer, Canada," Water Resources Research, Vol. 24, pp. 1747-1763.

, 1979. "Mass Transfer Among Minerals and Hydrothermal Solutions," in Geochemistry of Hydrothermal Ore Deposits, Second Edition, ed. by H. L. Barnes, John Wiley \& Sons, New York, pp. 568-610.

Parkhurst, D. L., D.C. Thorstenson, and L.N. Plummer, 1980. "PHREEQE-A Computer Program for Geochemical Calculations," U.S. Geol Sunvey Water-Resources Investigations Report, 80-96.

1982. "BALANCE-A Computer Program for Calculating Mass Transfer for Geochemical Reactions in Ground Water," U.S. Geol Suvvey Water-Resources Investigations Report, 82-14.

Phillips, F.M., H.W. Bentley, S.N. Davis, D. Elmore, and G.B. Swanick, 1986. "Chlorine 36 Dating of Very Old Groundwater 2. Milk River Aquifer, Alberta, Canada," Water Resources Research, Vol. 22, pp. 2003-2016.

Plummer, L.N., E.C. Prestemon, and D.L. Parkhurst, 1991. "An Interactive Code (NETPATH) for Modeling NET Geochemical Reactions Along a Flow Path," U.S. Geol Survey Water-Resources Investigations Report, 91-4078. 
Plummer, LN., D.L. Parkhurst, and D.C. Thorstenson, 1983. "Development of Reaction Models for Ground-Water Systems," Geochemical et Cosmochemical Acta, Vol. 47, pp. 665-686.

Sandia National Laboratories/New Mexico (Sandia/NM), 1993. Sandia National Laboratories Groundwater Monitoring Program Calendar Year 1992, Annual Report, Sandia National Laboratories/New Mexico, Albuquerque.

, 1994a. Sandia National Laboratories, Groundwater Protection Program, Calendar Year 1993 Annual Groundwater Monitoring Report, Sandia National Laboratories/New Mexico, Albuquerque.

, 1994b. Sandia National Laboratories Site-Wide Hydrogeologic Characterization Project, Calendar Year 1993 Annual Report, Sandia National Laboratories/New Mexico, Albuquerque.

1995. Sandia National Laboratories, Groundwater Protection Program

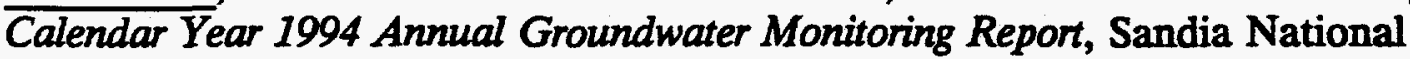
Laboratories/New Mexico, Albuquerque.

Schwartz, F.W., and K. Muehlenbachs, 1979. "Isotope and Ion Geochemistry of Groundwaters in the Milk River Aquifer, Alberta," Water Resources Research, Vol. 15, pp. 259-268.

Yapp, C. J., 1985. "D/H Variations of Meteoric Waters in Albuquerque, New Mexico, U.S.A.," Joumal of Hydrology, Vol. 76, pp. 63-84. 


\section{Appendix A}

\section{Geochemical Database (sand.dat) Used in this Study}

(a negative number indicates less than)

\section{References for this database are Sandia/NM 1993,} 1994a, and 1995. 
sand. dat

This file includes the entire database put together by stan Morrison for the Geochemistry site-Wide study. It does not exclude any of the analyses. sand. 1 etc are amended databases that exclude some data. Backup copy is store in /b

HISTORY:

3/1/95-3/7/95 First compilation of data. Includes $A 1 K, B r$, $\mathrm{Cl}, \mathrm{F}, \mathrm{pH}, \mathrm{SO} 4, \mathrm{Ca}, \mathrm{Fe}, \mathrm{Mg}, \mathrm{K}, \mathrm{NPN}$, and $\mathrm{NO} 3$.

$3 / 7 / 95$ Replaced all non-detects with negative numbers.

3/7/95 Recalculated $1992 \mathrm{alk}$ data as mg/L CaCo3 and entered.

$3 / 8 / 95$ Changed all alkalinities to field values.

3/8/95 Entered turbidity data (only 1994 available).

$3 / 10 / 95$ All entries checked for accurracy by Renee Rodgers.

$3 / 10 / 95 \mathrm{pH}$ entries changed from lab values to field values,

the last entry is the one that is used. Franz Lauffer said

that this last entry is the one that correlates to the

field alkalinity measurement.

3/23/95 Entered Ionic Str (PHREEQE), Carbon (PHREEQE), Cat/Anion (PHREEQE), SI calcite (PHREEQE), SI Gypsum (PHREEQE), and PCO2, atm (PHREEQE) fOr the "most representative" data.

5/1/95 Revised SI gYpsum by subtracting .246 from the previous numbers to adjust from $\log \mathrm{K}=-4.848$ to -4.602 which fits experimental data better $5 / 8 / 95$ Added the silica data

6/13/95 Added new well data: SFR-4T, PL-3, TRN-1, MRN-2, TJA-2, and PL-2.

$6 / 13 / 95$ Added $\mathrm{D} / \mathrm{H}$ and $180 / 160$ data

7/11/95 Corrected sand.dat following QA checks by Linda Gray. Only 2 additions to $\mathrm{D} / \mathrm{H}$ and $180 / 160$ were required plus rounding.

NOTES:

All are in $\mathrm{mg} / \mathrm{L}$ except $\mathrm{pH}$ (standard $\mathrm{pH}$ units), alkalinity (mg/L of Caco3), and turbidity (NTU units).

Non-detects are 1 isted as negative numbers

Alkalinities are field measurements as far as can be determined.

A blank line indicates that no data are available.

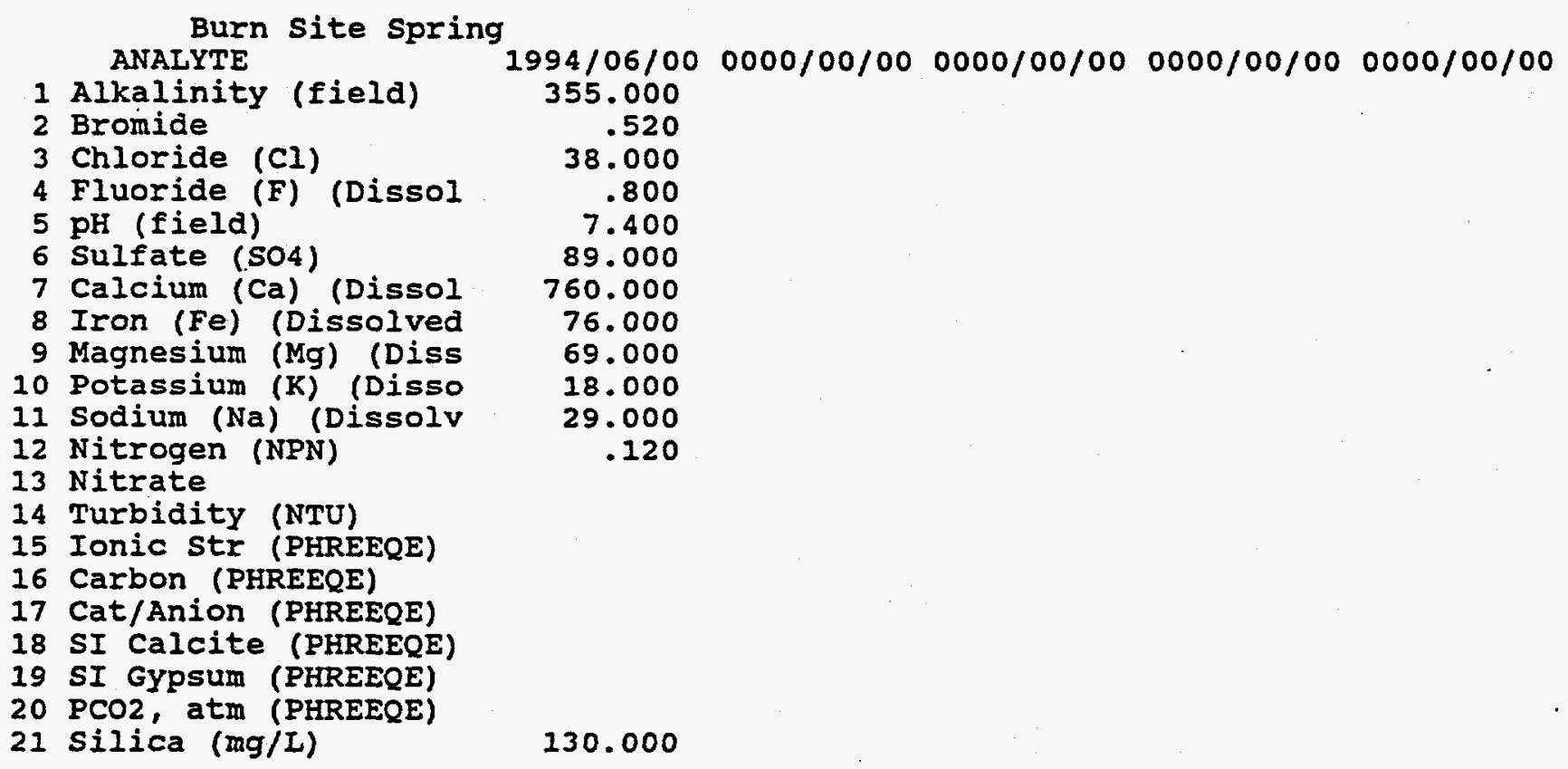




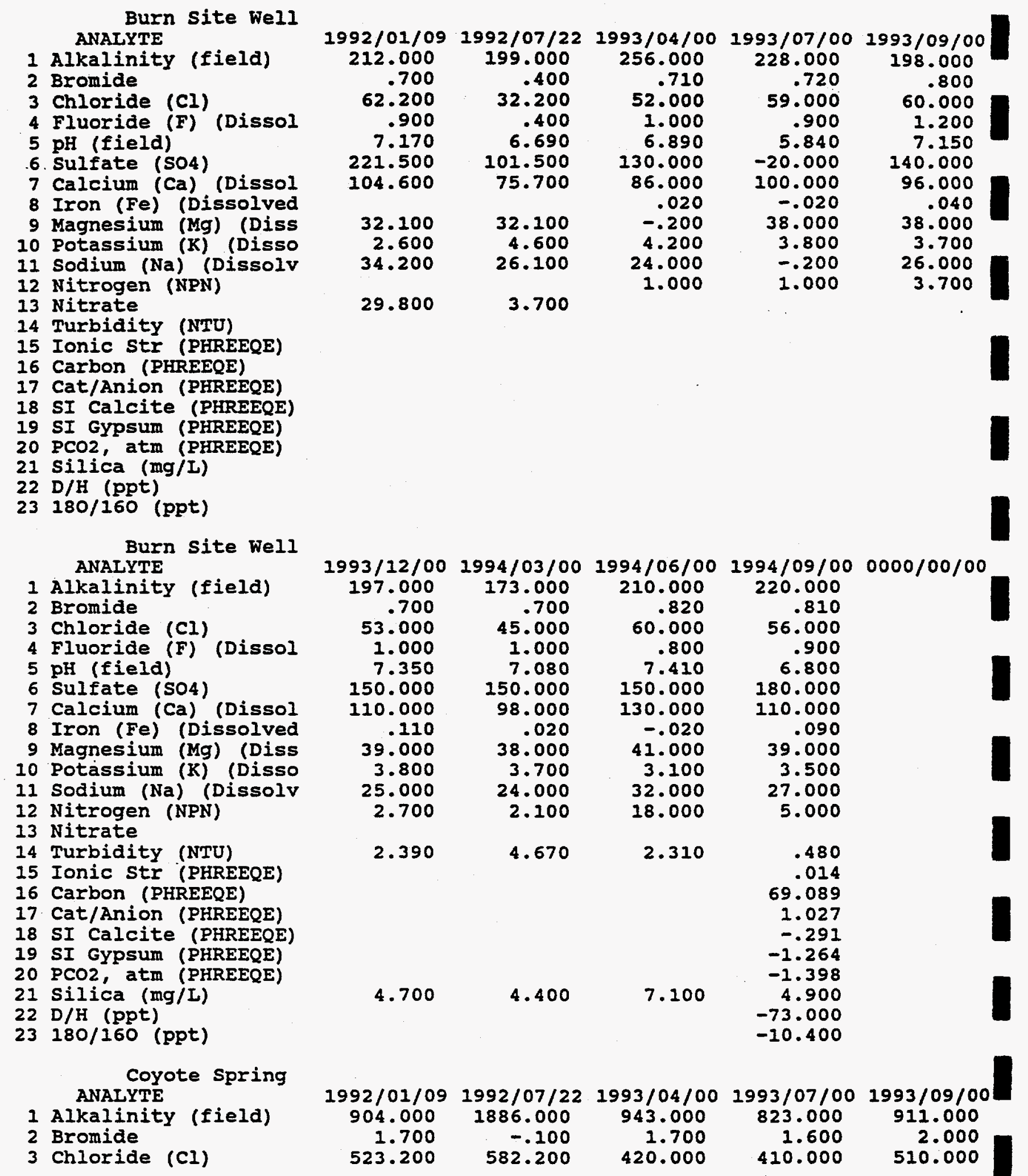


4 Fluoride (F) (Dissol

$5 \mathrm{pH}$ (field)

6 Sulfate (SO4)

7 Calcium (Ca) (Dissol

8 Iron (Fe) (Dissolved

9 Magnesium (Mg) (Diss

10 Potassium (K) (Disso

11 Sodium (Na) (Dissolv

12 Nitrogen (NPN)

13 Nitrate

14 Turbidity (NTU)

15 Ionic Str (PHREEQE)

16 Carbon (PHREEQE)

17 Cat/Anion (PHREEQE)

18 SI Calcite (PHREEQE)

19 SI Gypsum (PHREEQE)

$20 \mathrm{PCO} 2$, atm (PHREEQE)

21 Silica (mg/L)

22 D/H (ppt)

$23180 / 160$ (ppt)

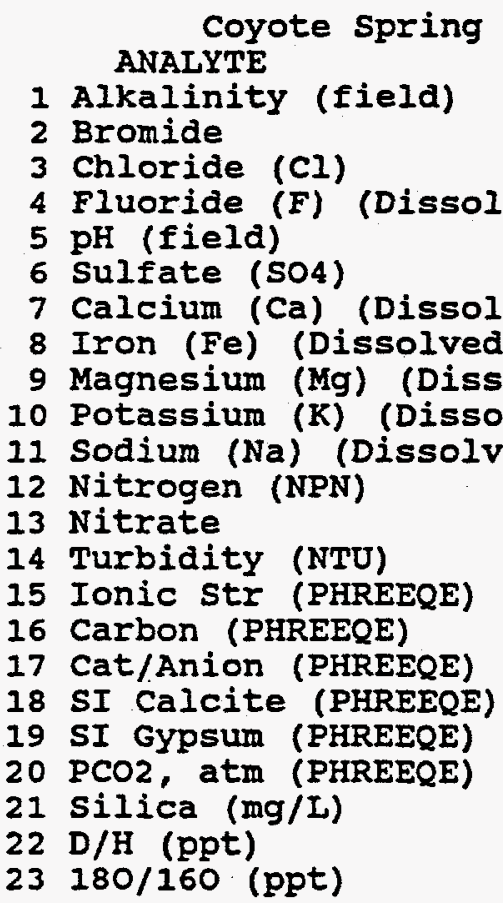

\begin{tabular}{|c|c|c|c|c|}
\hline $\begin{array}{r}1993 / 12 / 00 \\
956.000 \\
2.000 \\
530.000 \\
2.300 \\
6.200 \\
130.000 \\
270.000 \\
.900 \\
61.000 \\
28.000 \\
200.000 \\
.400\end{array}$ & $\begin{array}{r}1994 / 03 / 00 \\
2.100 \\
540.000 \\
1.700 \\
6.100 \\
150.000 \\
300.000 \\
.630 \\
61.000 \\
28.000 \\
380.000 \\
.350\end{array}$ & $\begin{array}{r}1994 / 06 / 00 \\
893.000 \\
2.100 \\
510.000 \\
1.700 \\
6.150 \\
110.000 \\
290.000 \\
1.800 \\
60.000 \\
28.000 \\
360.000 \\
.370\end{array}$ & $\begin{array}{r}1994 / 09 / 00 \\
202.000 \\
2.000 \\
500.000 \\
1.700 \\
6.160 \\
120.000 \\
280.000 \\
1.200 \\
62.000 \\
29.000 \\
400.000 \\
.500\end{array}$ & \\
\hline 8.000 & 11.500 & $\begin{array}{r}18.800 \\
.044 \\
486.304 \\
1.038 \\
-.049 \\
-1.320 \\
-.174 \\
8.400\end{array}$ & $\begin{array}{r}8.200 \\
-87.000 \\
-11.600\end{array}$ & \\
\hline $992 / 01 / 15$ & $\begin{array}{r}1992 / 07 / 29 \\
368.500 \\
1.000 \\
118.600 \\
2.200 \\
7.100 \\
81.200 \\
88.700 \\
\\
26.700 \\
7.300 \\
71.600\end{array}$ & $\begin{array}{r}1993 / 04 / 00 \\
363.000 \\
.200 \\
17.000 \\
.500 \\
7.140 \\
60.000 \\
120.000 \\
4.400 \\
29.000 \\
6.300 \\
85.000\end{array}$ & $\begin{array}{r}1993 / 07 / 00 \\
352.000 \\
.670 \\
130.000 \\
1.700 \\
6.800 \\
56.000 \\
140.000 \\
5.300 \\
32.000 \\
6.500 \\
82.000\end{array}$ & $\begin{array}{r}1993 / 09 / 00 \\
411.000 \\
.660 \\
120.000 \\
1.900 \\
6.820 \\
72.000 \\
126.000 \\
.370 \\
28.000 \\
6.300 \\
85.000\end{array}$ \\
\hline
\end{tabular}

$\begin{array}{rrrrr}2.300 & 3.500 & 1.400 & 15.000 & 2.200 \\ 6.170 & 6.090 & 5.920 & 5.720 & 6.000 \\ 144.900 & 138.500 & 92.000 & 10.000 & 100.000 \\ 239.700 & 208.900 & 240.000 & 250.000 & 250.000 \\ & & .180 & .220 & .300 \\ 53.500 & 50.200 & 50.000 & 52.000 & .570 \\ 26.800 & 27.400 & 24.000 & 24.000 & 26.000 \\ 308.400 & 316.800 & 330.000 & 340.000 & 370.000 \\ & & 1.300 & 1.200 & .640\end{array}$




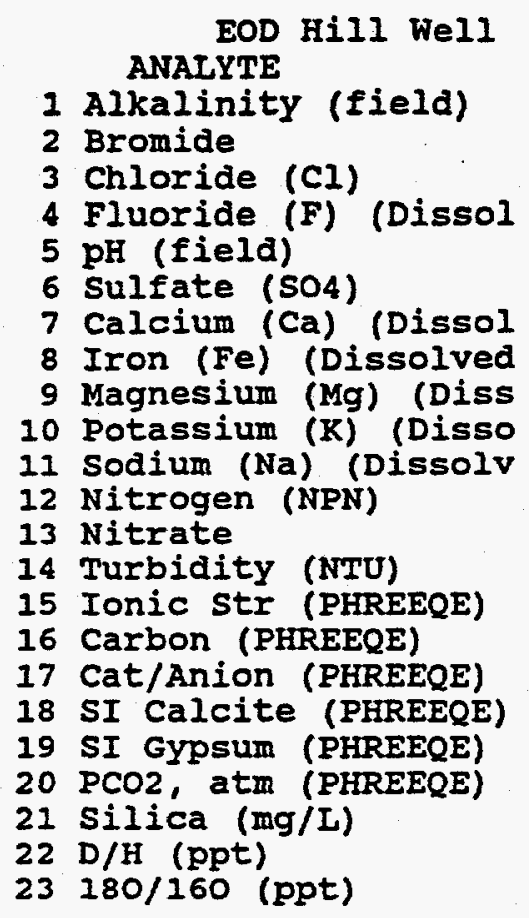

EOD Hill Well ANALYTE

1 Alkalinity (field)

2 Bromide

3 Chloride (CI)

4 Fluoride (F) (Dissol

$5 \mathrm{pH}$ (field)

6 Sulfate ( $\left.\mathrm{SO}_{4}\right)$

7 Calcium (Ca) (Dissol

8 Iron (Fe) (Dissolved

9 Magnesium (Mg) (Diss

10 Potassium (K) (Disso

11 Sodium (Na) (Dissolv

12 Nitrogen (NPN)

13 Nitrate

14 Turbidity (NTU)

15 IOnic Str (PHREEQE)

16 Carbon (PHREEQE)

17 Cat/Anion (PHREEQE)

18 SI Calcite (PHREEQE)

19 SI GYpsum (PHREEQE)

$20 \mathrm{PCO} 2$, atm (PHREEQE)

21 Silica (mg/L)

$22 \mathrm{D} / \mathrm{H}$ (ppt)

$23180 / 160$ (ppt)

$1993 / 12 / 0019$

1917.000

1.500

420.000

1.800

6.090

120.000

550.000

18.000

110.000

39.000

420.000

$-.050$

4.500

(n)

23.000

\section{Golf}

$$
\text { ANALYTE }
$$

1 Alkalinity (field)

2 Bromide

3 Chloride (Cl)

4 Fluoride (F) (Dissol

$5 \mathrm{pH}$ (field)

6 Sulfate (SO4)

7 Calcium (Ca) (Dissol

8 Iron ( $\mathrm{Fe}$ ) (Dissolved

9 Magnesium ( $\mathrm{Mg}$ ) (Diss

10 Potassium (K) (Disso

11 Sodium (Na) (Dissolv

12 Nitrogen (NPN)

13 Nitrate

14 Turbidity (NTU)

15 Ionic Str (PHREEQE)

16 carbon (PHREEQE)

17 Cat/Anion (PHREEQE)

18 SI Calcite (PHREEQE)

19 SI GYpsum (PHREEQE)

$20 \mathrm{PCO} 2$, atm (PHREEQE)

21 Silica (mg/L)

$22 \mathrm{D} / \mathrm{H}$ (ppt)

$23180 / 160$ (ppt)

South Well

1992/01/22

141.000

$-.100$

32.900

.500

8.220

53.000

14.500

15.100

1.200

20.200

96.400
$1994 / 03 / 00199$

$$
1997.000
$$

1.800

390.000

1.700

6.070

140.000

540.000

17.000

100.000

38.000

410.000

$-.050$

5.230

.067

1175.200

1.003

.392

$-1.121$

.237

22.000
$1994 / 06 / 00$

1869.000

2.200

390.000

1.600

6.170

95.000

520.000

17.000

100.000

39.000

420.000

$-.050$

5.230

24.000

24.000
-100.000
-13.800

2118.000

1.500

360.000

1.600

6.110

110.000

550.000

19.000

39.000

410.000

$-.050$

3.540
$1994 / 09 / 000000 / 00 / 00$
110.000

$1992 / 07 / 31$
118.000

$1993 / 04 / 00$

$1993 / 07 / 00$

$1993 / 09 / 00$

132.000

42.600

.610

44.000

.600

.400
7.490

72.900

7.700

59.000

71.300

87.000

$-.020$

18.200

2.800

15.000

23.100

$-.050$

22.000

20.000

21.000
.600
45.000
.400
7.430
60.000
83.000
$-.020$
16.000
2.400
20.000
20.000

$$
\begin{array}{r}
117.000 \\
.600 \\
44.000 \\
.400 \\
7.370 \\
55.000 \\
89.000 \\
-.020 \\
16.000 \\
2.600 \\
22.000 \\
19.000
\end{array}
$$

\footnotetext{
Golf course South Well

ANALYTE

1 Alkalinity (field)

$1993 / 12 / 001994 / 03 / 001994 / 06 / 00$ 96.000

123.000

$1994 / 09 / 000000 / 00 / 00$ 144.000
} 

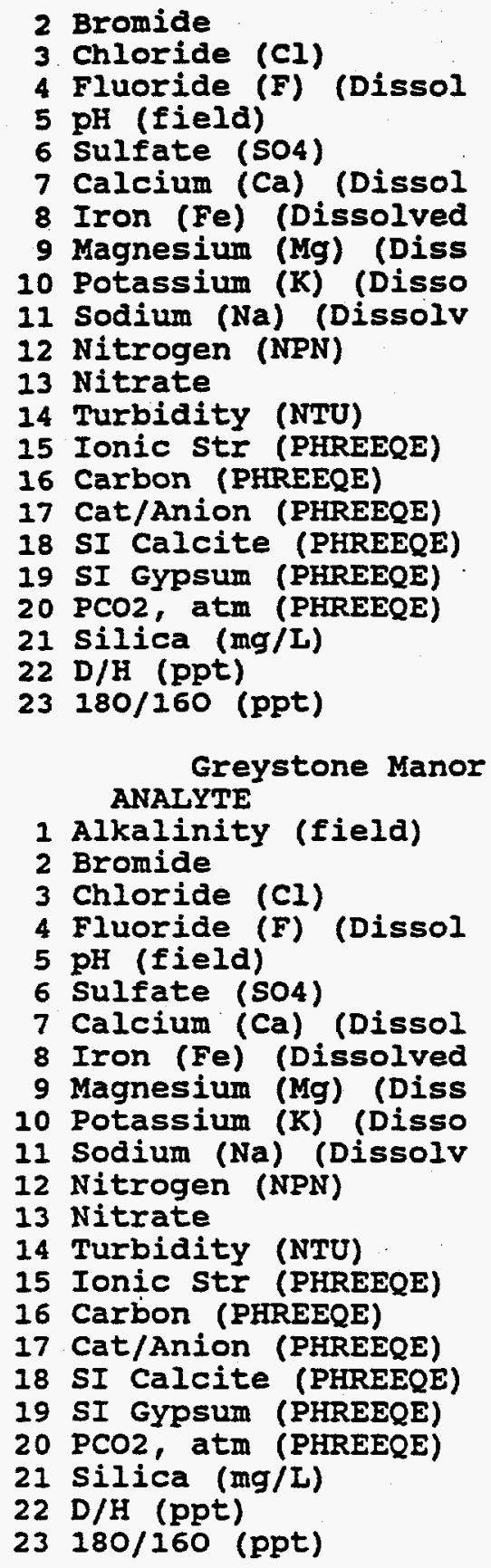

Well

$1992 / 01 / 161992 / 07 / 301993 / 04 / 001993 / 07 / 00$ 342.000

$-.100$

79.000

2.000

7.480

39.200

101.300

312.500

.500

143.100

1.300

7.580

79.500

62.200

25.200

3.200

61.300
22.900
5.100
59.500

21.800

35.200
.610
47.000

.500

7.410

68.000

85.000

.020

17.000

2.600

22.000

20.000

.160

13.000

$-74.000$
12.000

$-10.300$

3.000

.300

7.320

60.000

91.000

$-.020$

17.000

2.300

21.000

20.000

.840

$$
\begin{array}{r}
.440 \\
83.000 \\
.700 \\
5.970 \\
47.000 \\
120.000 \\
41.000 \\
25.000 \\
6.100 \\
65.000 \\
5.000
\end{array}
$$

$1993 / 09 / 00$

358.000

.480

88.000

.700

7.220

45.000

106.000

21.000

24.000

6.500

69.000

4.800

Greystone Manor Well

\footnotetext{
ANALYTE

1 Alkalinity (field)

2 Bromide

3 Chloride (Cl)

4 Fluoride (F) (Dissol

$5 \mathrm{pH}$ (field)

6 Sulfate ( $\mathrm{SO}_{4}$ )

7 Calcium (Ca) (Dissol

8 Iron (Fe) (Dissolved

9 Magnesium (Mg) (Diss
}

$1993 / 1$

$993 / 12 / 00$
279.000
.500
84.000
.700
7.180
44.000
110.000
3.500
25.000

$1994 / 03 / 00199$

$994 / 03 / 00$
256.000
.440
78.000
.620
7.110
-2.000
100.000
1.900
24.000
$1994 / 06 / 00$

309.000

.480

82.000

.700

7.350

50.000

110.000

11.000

26.000
$1994 / 09 / 000000 / 00 / 00$ 340.000

92.000

.600

6.940

45.000

110.000

22.000

27.000 
10 Potassium (K) (Disso

11 Sodium (Na) (Dissolv

12 Nitrogen (NPN)

13 Nitrate

14 Turbidity (NTU)

15 Ionic Str (PHREEQE)

16 Carbon (PHREEQE)

17 Cat/Anion (PHREEQE)

18 SI Calcite (PHREEQE)

19 SI GYPSUm (PHREEQE)

20 PCO2, atm (PHREEQE)

21 Silica (mg/L)

$22 \mathrm{D} / \mathrm{H}$ (ppt)

$23180 / 160$ (ppt)

Hubbell spring ANAIYTE

1 Alkalinity (field)

2 Bromide

3 Chloride (CI)

4 Fluoride (F) (Dissol

$5 \mathrm{pH}$ (field)

6 Sulfate (SO4)

7 Calcium (Ca) (Dissol

8 Iron (Fe) (Dissolved

9 Magnesium (Mg) (Diss

10 Potassium (K) (Disso

11 Sodium (Na) (Dissolv

12 Nitrogen (NPN)

13 Nitrate

14 Turbidity (NTU)

15 Ionic str (PHREEQE)

16 Carbon (PHREEQE)

17 Cat/Anion (PHREEQE)

18 SI Calcite (PHREEQE)

19 SI GYPsUm (PHREEQE)

$20 \mathrm{PCO} 2$, atm (PHREEQE)

21 Silica (mg/L)

$22 \mathrm{D} / \mathrm{H}$ (ppt)

23 180/160 (ppt)

Hubbell spring

\section{ANALYTE}

1 Alkalinity (field)

2 Bromide

3 Chloride (Cl)

4 Fluoride (F) (Dissol

$5 \mathrm{pH}$ (field)

6 Sulfate (SO4)

7 Calcium (Ca) (Dissol

8 Iron (Fe) (Dissolved

9 Magnesium (Mg) (Diss

10 Potassium (K) (Disso

11 Sodium (Na) (Dissolv

12 Nitrogen (NPN)

13 Nitrate

14 Turbidity (NTU)

15 Ionic Str (PHREEQE)

16 carbon (PHREEQE)

17 Cat/Anion (PHREEQE)

$\begin{array}{rrrr}4.600 & 4.600 & 6.000 & 6.000 \\ 64.000 & 64.000 & 65.000 & 69.000 \\ 5.000 & 3.800 & 4.900 & 4.500 \\ & & & \\ 137.000 & 129.000 & 93.600 & 191.000 \\ & & & .014 \\ & & & 99.724 \\ 1.054 \\ & & & .064 \\ & & & -1.837 \\ & & & -1.350 \\ 13.000 & 7.700 & 11.0000 & 11.000 \\ & & & -73.000 \\ & & & -10.300\end{array}$

$\begin{array}{rr}1992 / 01 / 10 & 1992 / 07 / 22 \\ 189.000 & 169.500 \\ .300 & .300 \\ 29.900 & 31.900 \\ 1.100 & .500 \\ 7.400 & 7.380 \\ 281.500 & 278.800 \\ 78.200 & 79.200 \\ 30.100 & 32.800 \\ 1.100 & 1.900 \\ 53.400 & 56.400 \\ 3.100 & 2.700 \\ & \end{array}$

$1993 / 04 / 00$

$1993 / 07 / 001993 / 09 / 00$ 192.000

238.000

178.000

35.000

.350

34.000

.900

6.200

6.690

220.000

74.000

$-.020$

32.000

1.400

54.000

.750

180.000

82.000

$-.020$

32.000

2.600

57.000

.740

.400

34.000

1.000

7.710

190.000

77.000

$-.020$

32.000

1.400

56.000

.690

.013

128.254

.975

$-.978$

$-1.362$

$-.760$

19

$1993 / 12 / 001994 / 03 / 001994 / 06 / 001994 / 09 / 00 \quad 0000 / 00 / 00$

$\begin{array}{llll}165.000 & 143.000 & 190.000 & 1042.000\end{array}$

$\begin{array}{rrrr}.300 & .340 & .320 & .480\end{array}$

$32.000 \quad 21.000$

$.900 \quad .900$

7.630

220.000

7.510

85.000

210.000

80.000

$-.020$

$-.020$

32.000

30.000

1.000

7.970

180.000

82.000

$-.020$

33.000

31.000

1.200

1.200

57.000

53.000

31.000

1.400

.700

.640

53.000

.790

.800

7.320

210.000

80.000

.030

32.000

1.300

56.000

.900

.610

3.060

1.310

.730 
18 SI Calcite (PHREEQE)

19 SI GYPSUm (PFREEQE)

20 PCO2, atm (PHREEQE)

21 Silica (mg/L)

$22 \mathrm{D} / \mathrm{H}$ (ppt)

$23180 / 160$ (ppt)

KAFB-10 We11

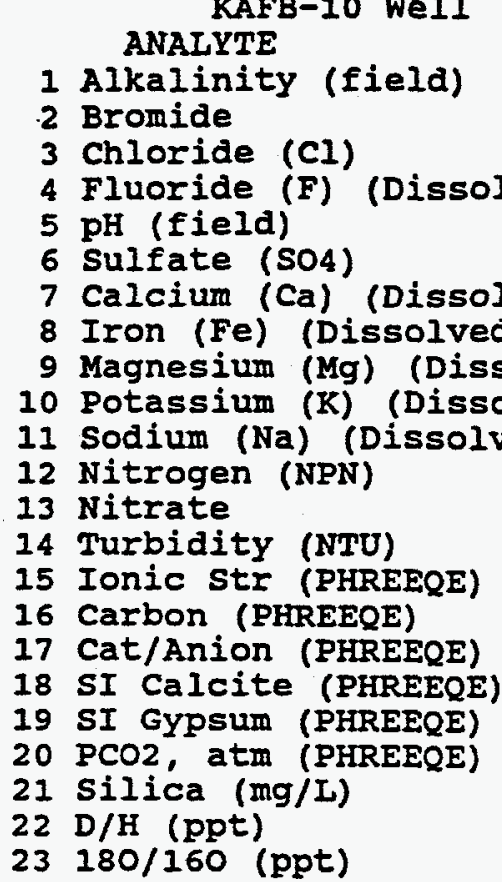

KAFB-10 Well

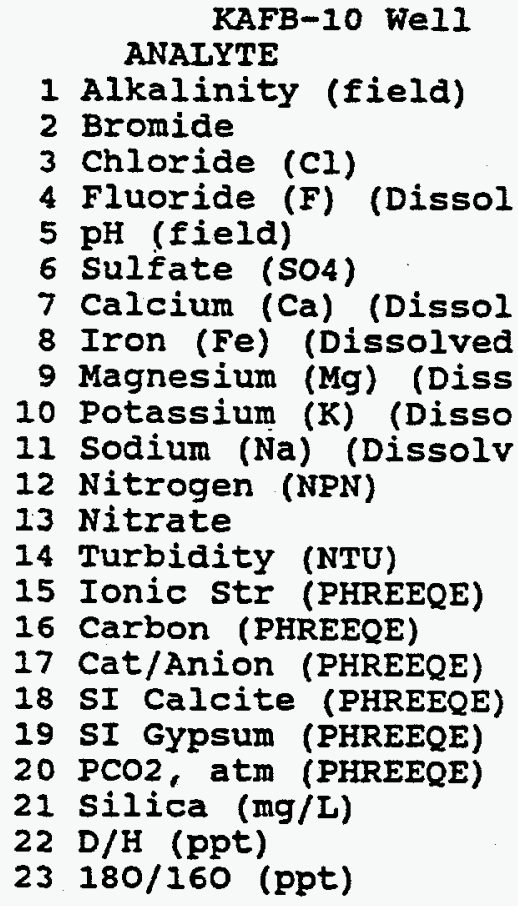

$1993 / 12 / 001994 / 03 / 00$

1.600 .007

16.357

.912

$-.551$

$-2.244$

$-2.693$

1.500

9.100

5.000

57.000
14.000

$-76.000$

$-10.100$ 65.000

.300

130.000

1.300

7.580

48.000

27.000

11.000

6.000

70.000

.800

30.200

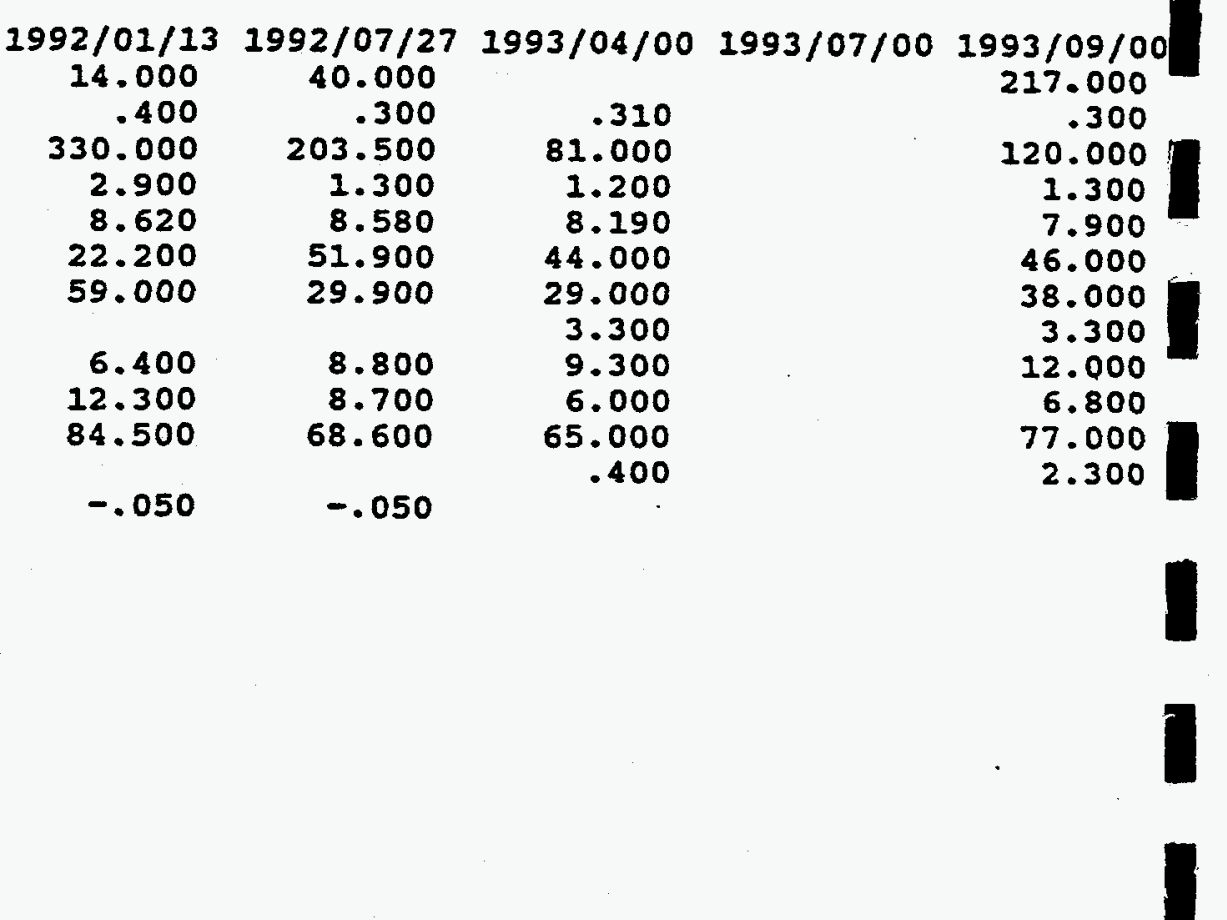

$1994 / 06 / 001994 / 09 / 000000 / 00 / 00$

70.000

1.300

7.380

58.000

47.000

16.000

15.000

6.200

62.000

2.800

108.000

391.000

.330

98.000

1.600

7.680

45.000

37.000

4.700

12.000

4.500

3.400

30.500

LF/DM-1 WeII 
ANAIYTE

1 Alkalinity (fiela)

2 Bromide

3 Chloride (Cl)

4 Fluoride (F) (Dissol

$5 \mathrm{pH}$ (field)

6 Sulfate (S04)

7 Calcium (Ca) (Dissol

8 Iron (Fe) (Dissolved

9 Magnesium (Mg) (Diss

10 Potassium (K) (Disso

11 Sodium (Na) (Dissolv

12 Nitrogen (NPN)

13 Nitrate

14 Turbidity (NTU)

15 Ionic Str (PHREEQE)

16 carbon (PHREEQE)

17 Cat/Anion (PHREEQE)

18 SI Calcite (PHREEQE)

19 SI Gypsum (PHREEQE)

$20 \mathrm{PCO} 2$, atm (PHREEQE)

21 silica (mg/L)

$22 \mathrm{D} / \mathrm{H}$ (ppt)

$23180 / 160$ (ppt)

LF/DM-1 WeII

\section{ANATYTE}

1 Alkalinity (field)

2 Bromide

3 Chloride (Cl)

4 Fluoride (F) (Dissol

$5 \mathrm{pH}$ (field)

6 Sulfate (SO4)

7 Calcium (Ca) (Dissol

8 Iron (Fe) (Dissolved

9 Magnesium (Mg) (Diss

10 Potassium (K) (Disso

11 Sodium (Na) (Dissolv

12 Nitrogen (NPN)

13 Nitrate

14. Turbidity (NTU)

15 Ionic str (PHREEQE)

16 Carbon (PHREEQE)

17 Cat/Anion (PHREEQE)

18 SI Calcite (PHREEQE)

19 SI GYPsum (PHREEQE)

20 PCO2, atm (PHREEQE)

21 Silica (mg/L)

$22 \mathrm{D} / \mathrm{H}$ (ppt)

$23180 / 160$ (ppt)

\author{
LF/DM-2 We11 \\ ANALYTE \\ 1 Alkalinity (field) \\ 2 Bromide \\ 3 Chloride (Cl) \\ 4 Fluoride (F) (Dissol \\ $5 \mathrm{pH}$ (field) \\ 6 Sulfate (SO4) \\ 7 Calcium (Ca) (Dissol
}

$1992 / 01 / 24$

105.500

$-.100$

18.100

1.300

8.020

22.300

25.700

$\begin{array}{rrr}4.300 & 5.000 \\ 1.000 & 2.200 \\ 17.100 & & 18.400 \\ -.050 & & -.050\end{array}$

$1993 / 12 / 00$

98.000

$-.050$

6.000

.500

7.930

27.000

30.000

.030

4.700

2.100

18.000

$-.050$

.500

.004

23.868

1.012

.067

$-2.370$

$-2.859$

17.000
$1992 / 08 / 06$

\subsection{0}

$-.100$

4.200

0.300

8.000

21.300

29.100

$-.050$
$1993 / 04 / 00$

$1993 / 07 / 00$

40.000

$-.100$

6.300

.500

7.980

27.000

32.000

.040

5.100

2.300

19.000

.450
$1993 / 09 / 00$

103.000

$-.100$

6.600

.500

7.760

26.000

32.000

$-.020$

4.900

2.000

18.000

$-.050$
$1994 / 03 / 00$

\subsection{0}

$-.050$

5.800

0.500

7.670

28.000

30.000

.040

4.900

2.100

19.000

.050

.600

17.000

16.000

16.000

$-100.000$

$-13.700$
$1994 / 06 / 00$

102.000

$-.050$

5.600

7.800

25.000

32.000

.020

5.000

0.000

$-.050$

.610

.490

$94 / 09 / 00$
112.000

$-.100$

6.600

7.840

26.000

30.000

$-.020$

2.000

.000

.070

$$
\begin{array}{rrrrr}
1992 / 01 / 23 & 1992 / 08 / 04 & 1993 / 04 / 00 & 1993 / 07 / 00 & 1993 / 09 / 00 \\
177.000 & 140.500 & 157.000 & 782.000 & 138.000 \\
-.100 & -.100 & .210 & .180 & .180 \\
15.300 & 15.500 & 15.000 & 16.000 & 16.000 \\
-.100 & .300 & .300 & .400 & .400 \\
8.200 & 7.530 & 7.700 & 7.320 & 7.430 \\
76.300 & 96.100 & 74.000 & 79.000 & 66.000 \\
61.300 & 55.800 & 271.000 & 71.000 & 70.000
\end{array}
$$

$0000 / 00 / 00$ 


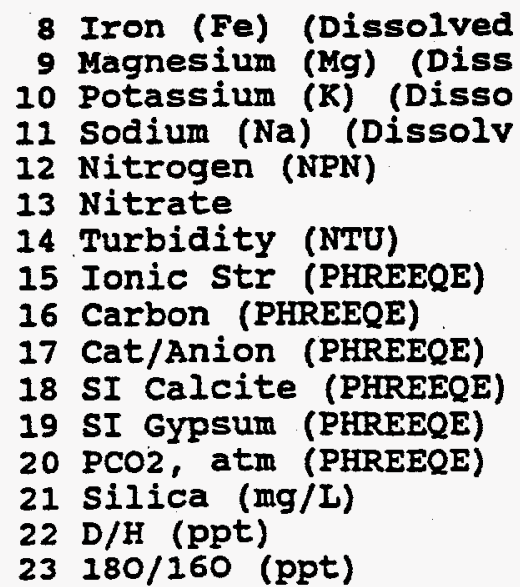

IF/DM-2 WeIl ANALYTE

1 Alkalinity (field)

2 Bromide

3 Chloride ( $\mathrm{Cl}$ )

4 Fluoride (F) (Dissol

$5 \mathrm{pH}$ (field)

6 Sulfate ( $\mathrm{SO} 4$ )

7 Calcium (Ca) (Dissol

8 Iron (Fe) (Dissolved

9 Magnesium (Mg) (Diss

10 Potassium (K) (Disso

11 Sodium (Na) (Dissolv

12 Nitrogen (NPN)

13 Nitrate

14 Turbiaity (NTU)

15 Ionic Str (PHREEQE)

16 Carbon (PHREEQE)

17 Cat/Anion (PHREEQE)

18 SI Calcite (PHREEQE)

19 SI Gypsum (PHREEQE)

$20 \mathrm{PCO} 2$, atm (PHREEQE)

21 Silica (mg/L)

$22 \mathrm{D} / \mathrm{H}$ (ppt)

$23180 / 160$ (ppt)

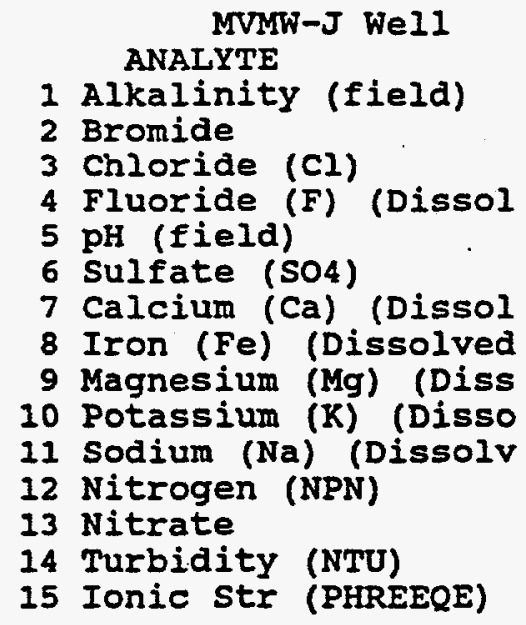

$\begin{array}{rrr}12.000 & 13.100 & 13.030 \\ 1.300 & 2.600 & 2.300 \\ 22.200 & 23.500 & 24.000 \\ & & 4.000\end{array}$

18.700

19.200

1993

$\begin{array}{rrr}993 / 12 / 00 & 1994 / 03 / 00 & 1994 / 06 / 00 \\ 146.000 & 167.000 & 136.000 \\ .200 & .190 & .190 \\ 16.000 & 17.000 & 15.000 \\ .320 & .400 & .400 \\ 7.320 & 7.340 & 7.410 \\ 78.000 & 80.000 & 69.000 \\ 66.000 & 73.000 & 73.000 \\ .120 & .060 & .150 \\ 12.000 & 13.000 & 14.000 \\ 2.100 & 2.400 & 2.600 \\ 22.000 & 24.000 & 26.000 \\ 4.000 & 2.000 & 4.000 \\ 4.300 & 1.350 & 6.470\end{array}$

14.000

14.000

14.000

$1994 / 09 / 000000 / 00 / 00$

175.000

17.000

.300

7.350

77.000

72.000

.070

13.000

2.300

24.000

4.200

3.050

.008

45.603

1.035

.048

$-1.680$

$-2.037$

13.000

$-74.000$

$-10.600$

199

$\begin{array}{rrr}992 / 01 / 21 & 1992 / 08 / 07 & 1993 / 04 / 00 \\ 94.500 & 96.500 & 145.000 \\ -.100 & -.100 & .120 \\ 11.000 & 6.800 & 9.100 \\ -.100 & .300 & .400 \\ 7.950 & 7.780 & 7.300 \\ 23.300 & 27.400 & 25.000 \\ 29.900 & 33.000 & 44.000 \\ & & 2.700 \\ 3.600 & 4.300 & 5.900 \\ 1.000 & 2.200 & 2.800 \\ 16.600 & 17.500 & 20.000 \\ & & .560\end{array}$

$1993 / 07 / 00$

$1993 / 09 / 00$

$$
\begin{array}{rr}
85.000 & 140.000 \\
-.100 & .100 \\
8.300 & 7.500 \\
.400 & .300 \\
6.780 & 7.740 \\
24.000 & 30.000 \\
52.000 & 54.000 \\
2.200 & 3.500 \\
6.000 & 6.300 \\
3.100 & 3.000 \\
20.000 & 20.000 \\
13.000 & 14.000
\end{array}
$$


16 Carbon (PHREEQE)

17 Cat/Anion (PHREEOE)

18 SI Calcite (PHREEQE)

19 SI Gypsum (PHREEQE)

$20 \mathrm{PCO} 2$, atm (PHREEQE)

21 Silica (mg/L)

$22 \mathrm{D} / \mathrm{H}$ (ppt)

$23180 / 160$ (ppt)

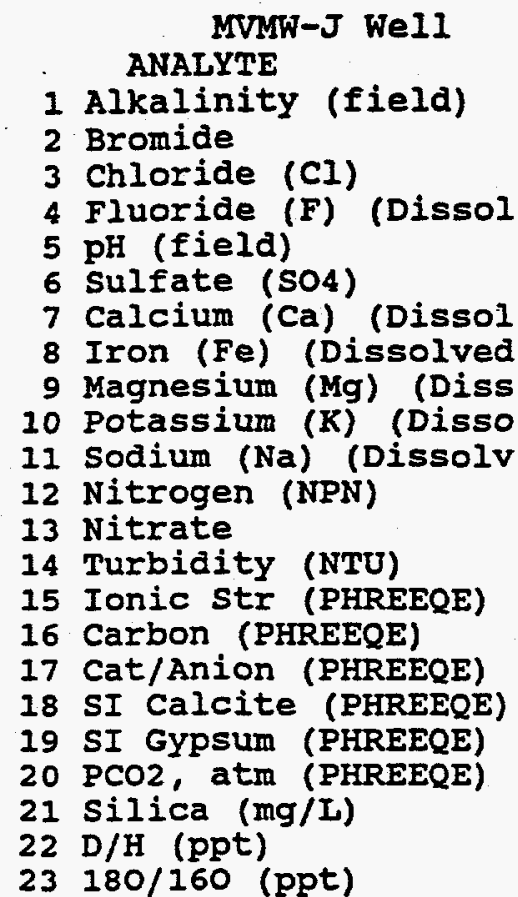

MVMW-K Well

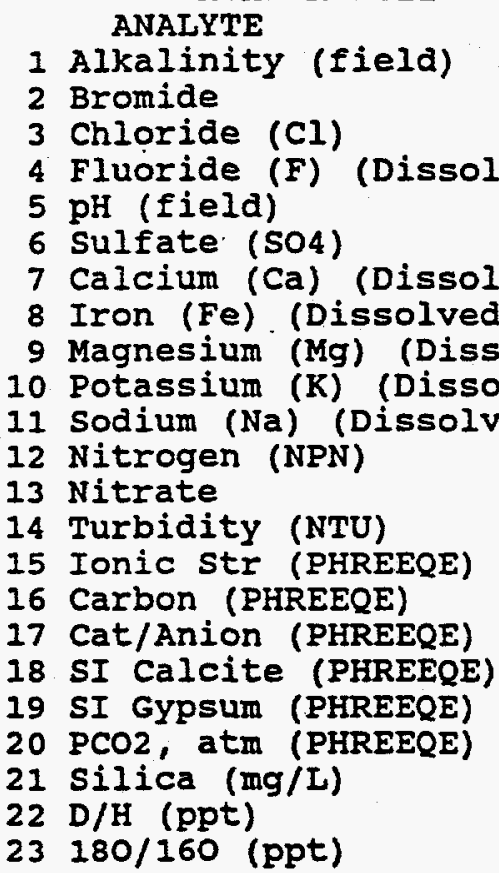

1

\section{9}

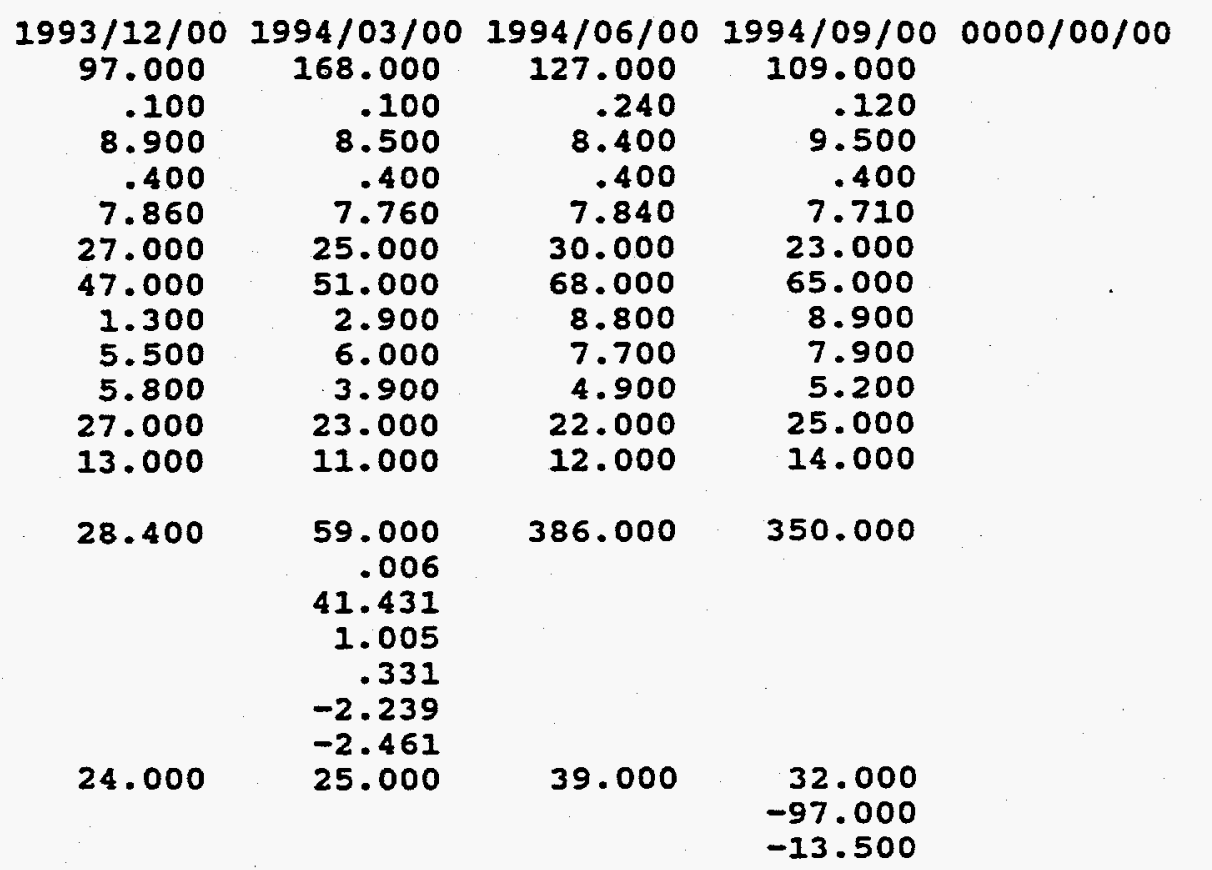


MVMW-K พeII

ANALYTE

1 Alkalinity (field)

2 Bromide

3 Chloride (CI)

4 Fluoride (F) (Dissol

$5 \mathrm{pH}$ (field)

6 Sulfate (SO4)

7 Calcium (Ca) (Dissol

8 Iron (Fe) (Dissolved

9 Magnesium (Mg) (Diss

10 Potassium (K) (Disso

11 Sodium (Na) (Dissolv

12 Nitrogen (NPN)

13 Nitrate

14 Turbidity (NTU)

15 Ionic Str (PHREEQE)

16 Carbon (PHREEQE)

17 Cat/Anion (PHREEQE)

18 SI Calcite (PHREEQE)

19 SI Gypsum (PHREEQE)

$20 \mathrm{PCO} 2$, atm (PHREEQE)

21 Silica (mg/L)

$22 \mathrm{D} / \mathrm{H}$ (ppt)

23 180/160 (ppt)

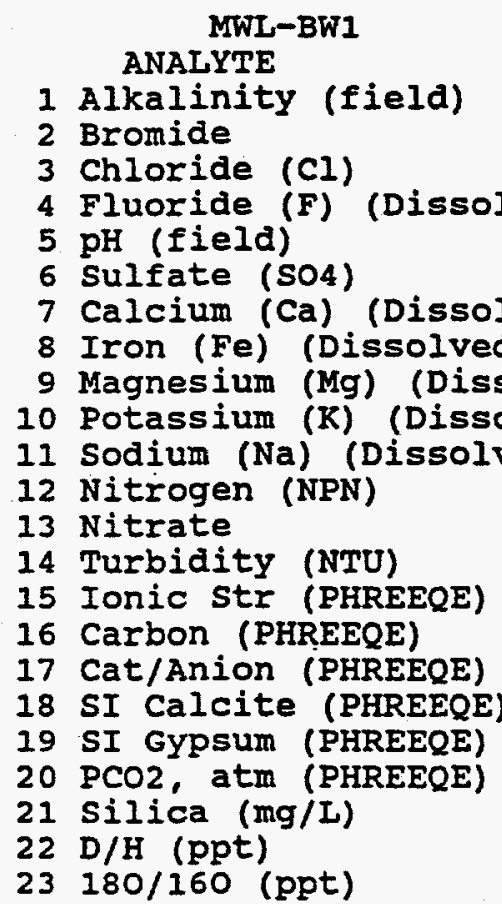

MWL-BWI

\section{ANALYTE}

1 Alkalinity (field)

2 Bromide

3 Chloride (Cl)

4 Fluoride (F) (Dissol

$5 \mathrm{pH}$ (field)
$1993 / 12 / 001994 / 03 / 00$

92.000

.100

.400

7.760

30.000

59.000

2.400

6.500

5.000

29.000

20.000

63.200

19.000

33.000

.080

8.900

.400

7.600

65.000

11.000

7.000

4.900

23.000

7.800

434.000

$1994 / 06 / 00$

98.000

.110

8.600

.500

7.930

40.000

50.000

5.900

6.400

5.000

26.000

14.000

720.000

$1994 / 09 / 000000 / 00 / 00$

126.000

$-.100$

10.000

.400

7.900

38.000

65.000

14.000

7.600

5.400

26.000

31.000

357.000
10.000

35.000
36.000

-99.000
-13.500

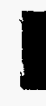

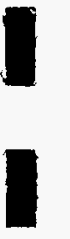

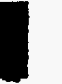

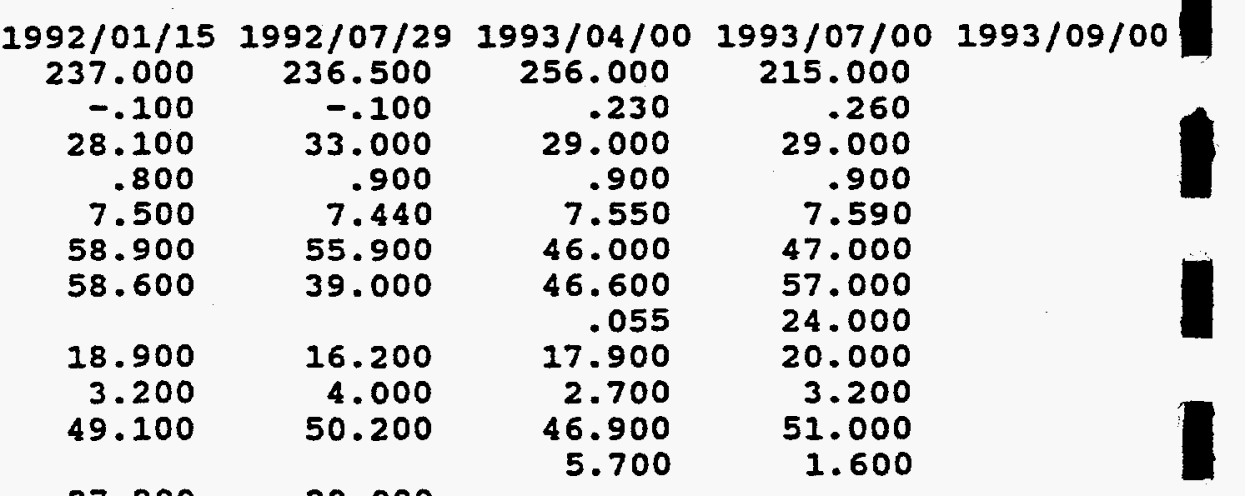

$\begin{array}{rrrr}1993 / 12 / 00 & 1994 / 03 / 00 & 1994 / 06 / 00 & 1994 / 09 / 00 \\ 173.000 & & 203.000 & 234.000 \\ .230 & .260 & .220 & -.100 \\ 28.000 & 29.000 & 29.000 & 25.600 \\ .900 & .900 & .900 & .790 \\ 7.460 & 7.700 & 7.770 & 7.530\end{array}$


6 Sulfate (SO4)

7 Calcium (Ca) (Dissol

8 Iron (Fe) (Dissolved

9 Magnesium (Mg) (Diss

10 Potassium (K) (Disso

11 Sodium (Na) (Dissolv

12 Nitrogen (NPN)

13 Nitrate

14 Turbidity (NTU)

15 Ionic Str (PHREEQE)

16 Carbon (PHREEQE)

17 cat/Anion (PHREEQE)

18 SI Calcite (PHREEQE)

19 SI Gypsum (PHREEQE)

20 PCO2, atm (PHREEQE)

21 Silica (mg/L)

22 D/H (ppt)

$23180 / 160$ (ppt)

NW-TA3 Well ANALYTE

1 Alkalinity (field)

Bromide

3 Chloride (Cl)

4 Fluoride (F) (Dissol

5 pH (field)

6 Sulfate (SO4)

7 Calcium (Ca) (Dissol

8 Iron (Fe) (Dissolved

9 Magnesium (Mg) (Diss

10 Potassium (K) (Disso

11 Sodium (Na) (Dissolv

12 Nitrogen (NPN)

13 Nitrate

14 Turbidity (NTU)

15 Ionic str (PHREEQE)

16 carbon (PHREEQE)

17 Cat/Anion (PHREEQE)

18 SI Calcite (PHREEQE)

19 SI Gypsum (PHREEQE)

$20 \mathrm{PCO} 2$, atm (PHREEQE)

21 silica (mg/L)

22 D/H (ppt)

$23180 / 160$ (ppt)

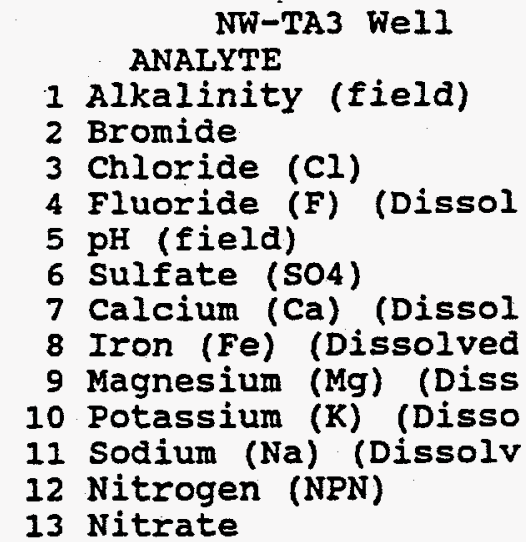

NW-TA3 Well

Alkalinity (field)

Bromide

Chloride (C)

Fluoride (F) (Dissol

pH (field)

Sulfate (SO4)

Calcium (Ca) (Dissol

Iron (Fe) (Dissolved

9 Magnesium (Mg) (Diss

10 Potassium (K) (Disso

11 sodium (Na) (Dissolv

13 Nitrate

$\begin{array}{rrrr}45.000 & 52.000 & 49.000 & 42.500 \\ 55.000 & 54.000 & 55.000 & 55.800 \\ .030 & .110 & .130 & .057 \\ 20.000 & 19.000 & 20.000 & 20.000 \\ 3.300 & 3.100 & 3.100 & 3.500 \\ 52.000 & 50.000 & 52.000 & 56.900 \\ 5.600 & 5.400 & 5.500 & 5.600 \\ .640 & 2.020 & 14.100 & 1.900 \\ & & & .009 \\ & & & 59.177 \\ & & & -2.117 \\ & & & -2.050 \\ & & & \end{array}$

$1992 / 01 / 001992 / 07 / 281993 / 04 / 001993 / 07 / 00$

$\begin{array}{rr}165.000 & 155.000 \\ -.100 & .640 \\ 17.500 & 130.000 \\ .300 & 1.700 \\ 7.340 & 7.590 \\ 81.300 & 73.000 \\ 43.900 & 56.000 \\ & -.020 \\ 13.000 & 15.000 \\ 4.700 & 43.000 \\ 20.900 & 22.000 \\ & 1.500\end{array}$

26.900

30.000

6.300

.300

7.320

86.200

54.400

14.400

4.300

1. 500
.210

16.000

.400

7.400

56.000

63.000

.660

16.000

4.700

22.000

6.400

$1993 / 09 / 00$

153.000

.210

17.000

.400

7.510

75.000

61.000 .090

15.000

4.400

22.000

6.200

.008

38.815

1.052

.084

$-1.748$

$-2.25 .4$

$$
\begin{aligned}
& 1993 / 12 / 001994 / 03 / 001994 / 06 / 00 \quad 1994 / 09 / 000000 / 00 / 00 \\
& 157.000 \\
& 127.000 \\
& 115.000 \\
& 150.000 \\
& .240 \\
& .180 \\
& 16.000 \\
& .400 \\
& 7.290 \\
& 7.460 \\
& .020 \\
& -.020 \\
& \text { 6. } 000 \\
& 15.000 \\
& 4.400 \\
& 4.400 \\
& 21.000 \\
& \begin{array}{r}
22.000 \\
6.100
\end{array}
\end{aligned}
$$




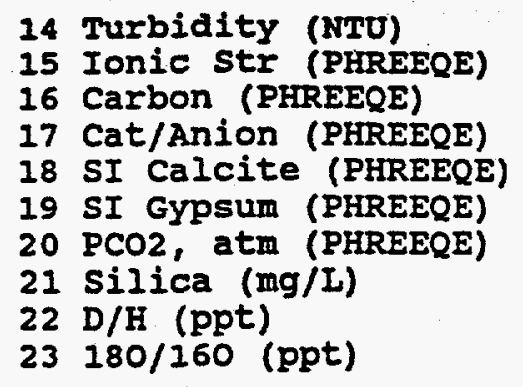

Schoolhouse Well

ANALYTE
1 Alkalinity (field)
2 Bromide
3 Chloride (Cl)
4 Fluoride (F) (Dissol
5 pH (field)
6 Sulfate (SO4)
7 Calcium (Ca) (Dissol
8 Iron (Fe) (Dissolved
9 Magnesium (Mg) (Diss
10 Potassium (K) (Disso
11 Sodium (Na) (Dissolv
12 Nitrogen (NPN)
13 Nitrate
14 Turbidity (NTU)
15 Ionic Str (PHREEQE)
16 Carbon (PHREEQE)
17 Cat/Anion (PHREEQE)
18 SI Calcite (PHREEQE)
19 SI Gypsum (PHREEQE)
20 PCO2, atm (PHREEQE)
21 Silica (mg/L)
22 D/H (ppt)
23 180/160 (Ppt)

$1992 / 01 / 161$

$$
\begin{array}{r}
427.500 \\
.600
\end{array}
$$

145.300

1.500

7.000

70.600

150.100

26.300
6.900

158.100

20.700

15.000

15.000

15.000

$-71.000$

$-10.300$
$92 / 07 / 30$
391.000
.700
-2.000
1.800
6.960
80.700

112.300

27.000

7.900

81.200

25.600$$
.018
$$

124.432

.976

.093

$-1.656$

$-1.163$

Schoolhouse Well

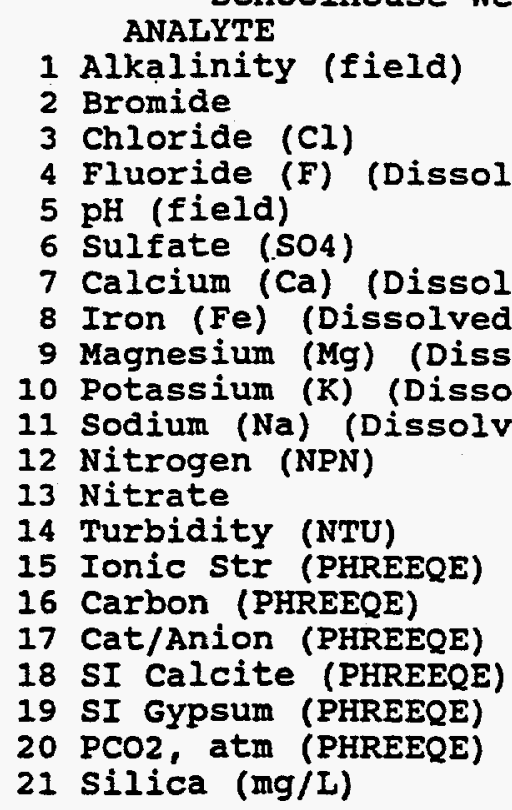

$1993 / 12 / 001994 / 03 / 0019$ 330.000

.720

150.000

1.400

6.760

62.000

140.000

1.600

25.000

6.000

90.000

3.500

5.920

9.600

10.000

6.900
$1994 / 06 / 00$ 376.000 .700

130.000

1.400

6.870

61.000

150.000

1.300

26.000

6.300

93.000

4.200

6.960

6.900

3.800

6.960

$1994 / 09 / 000000 / 00 / 00$
438.000
.710

160.000

1.400

6.600

62.000

150.000

1.100

26.000

5.900

88.000

4.400

5.390

$993 / 09 / 00$
268.000
.670
140.000
1.400
6.940
61.000
137.000
23.000
25.000
7.400
92.000
3.300

I
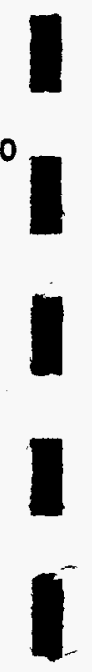
Sol se Mete spring

ANALYTE

1 Alkalinity (field)

2 Bromide

3 Chloride (Cl)

4 Fluoride (F) (Dissol

$5 \mathrm{pH}$ (field)

6 Sulfate (SO4)

7 Calcium (Ca) (Dissol

8 Iron (Fe) (Dissolved

9 Magnesium (Mg) (Diss

10 Potassium (K) (Disso

11 Sodium (Na) (Dissolv

12 Nitrogen (NPN)

13 Nitrate

14 Turbidity (NTU)

15 Ionic str (PHREEQE)

16 Carbon (PHREEQE)

17 Cat/Anion (PHREEQE)

18 SI Calcite (PHREEQE)

19 SI Gypsum (PHREEQE)

$20 \mathrm{PCO} 2$, atm (PHREEQE)

21 Silica (mg/L)

$22 \mathrm{D} / \mathrm{H}$ (ppt)

$23180 / 160$ (ppt)
$1992 / 02 / 05$

.400
25.900
.200
93.200
54.400
13.200
1.700
11.100
5.400

$1992 / 07 / 22$

205.000

.300

27.200

.500

6.800

97.800

85.400

15.600

1.700

11.700

5.500
$1993 / 04 / 00$

288.000

.400

25.000 .400

5.480

68.000

96.000

$-.020$

17.000

1.600

11.000

1.200
$1993 / 07 / 001993 / 09 / 00$

216.000

.420 .

27.000

.400

60.000

110.000

.040

17.000

1.700

11.000

1.300
225.000

.400

27.000

.500

7.340

65.000

100.000

$-.020$

17.000

1.600

11.000

1.200 ANAIYTE

Sol se Mete spring

1 Alkalinity (field)

2 Bromide

3 Chloride (Cl)

4 Fluoride (F) (Dissol

$5 \mathrm{pH}$ (field)

6 Sulfate (SO4)

7 Calcium (Ca) (Dissol

8 Iron (Fe) (Dissolved

9 Magnesium (Mg) (Diss

10 Potassium (K) (Disso

11 Sodium (Na) (Dissolv

12 Nitrogen (NPN)

13 Nitrate

14 Turbidity (NTU)

15 Ionic str (PHREEQE)

16 Carbon (PHREEQE)

$17 \mathrm{Cat} /$ Anion (PHREEQE)

18 SI Calcite (PHREEQE)

19 SI Gypsum (PHREEQE)

$20 \mathrm{PCO} 2$, atm (PHREEQE)

21 Silica (mg/L)

22 D/H (ppt)

$23180 / 160$ (ppt)
$1993 / 12 / 001994 / 03 / 00$

$$
.400
$$

26.000

.400

7.500

78.000

100.000

$-.020$

17.000

1.600

11.000

1.200

1.050

8.800

8.900

$$
\begin{aligned}
& \begin{array}{rr}
994 / 06 / 00 & 1994 / 09 / 00 \\
205.000 & 230.000
\end{array} \\
& \begin{array}{rr}
.400 & .370
\end{array} \\
& 24.000 \\
& .400 \\
& 7.530 \\
& 70.000 \\
& 110.000 \\
& -.020 \\
& 18.000 \\
& 1.600 \\
& 12.000 \\
& 1.300 \\
& .700 \\
& 24.000 \\
& 7.090 \\
& 81.000 \\
& 110.000 \\
& -.020 \\
& 17.000 \\
& 12.000 \\
& 1.100 \\
& .610
\end{aligned}
$$

South Fence Well \#1

ANALYTE

1 Alkalinity (field)

2 Bromide

3 Chloride (Cl)

\begin{abstract}
$1992 / 01 / 00$
$1992 / 07 / 00$
\end{abstract}$$
.010
$$$$
58.656
$$$$
1.048
$$$$
.274
$$$$
-1.656
$$$$
-1.923
$$ 


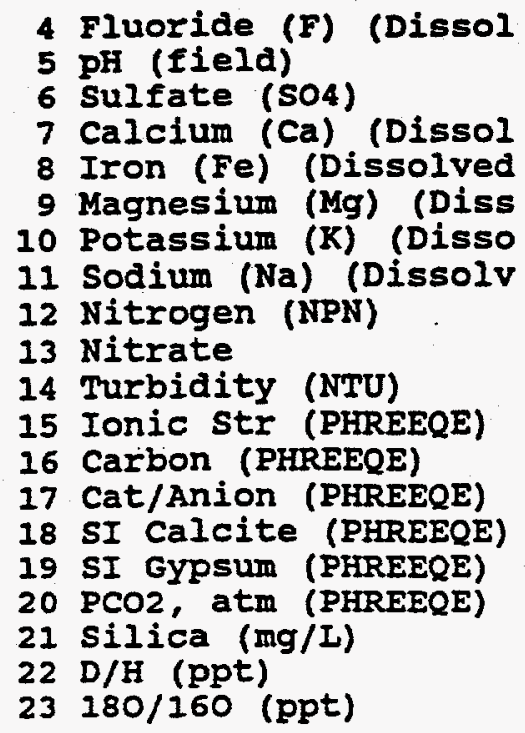

$\begin{array}{rrr}1.700 & 1.700 & 1.700 \\ 6.810 & 6.600 & 6.680 \\ 67.000 & 70.000 & 71.000 \\ 148.000 & 160.000 & 150.000 \\ .780 & -.020 & -.020 \\ 35.000 & 37.000 & 35.000 \\ 7.200 & 7.300 & 7.200 \\ 78.000 & 80.000 & 77.000 \\ .950 & .900 & .960\end{array}$

South Fence Well $\$ 1$

ANALYTE
1 Alkalinity (field)
2 Bromide
3 Chloride (Cl)
4 Fluoride (F) (Dissol
5 pH (field)
6 Sulfate (SO4)
7 Calcium (Ca) (Dissol
8 Iron (Fe) (Dissolved
9 Magnesium (Mg) (Diss
10 Potassium (K) (Disso
11 Sodium (Na) (Dissolv
12 Nitrogen (NPN)
13 Nitrate
14 Turbidity (NTU)
15 Ionic Str (PHREEQE)
16 Carbon (PHREEQE)
17 Cat/Anion (PHREEQE)
18 SI Calcite (PHREEQE)
19 SI Gypsum (PHREEQE)
20 PCO2, atm (PHREEQE)
21 Silica (mg/L)
22 D/H (ppt)
23 18O/i6o (PDt)
$1993 / 12 / 00 \quad 1994 / 03 / 00 \quad 1994 / 06 / 00$ $994 / 06 / 00$
380.000 $1994 / 09 / 000000 / 00 / 00$ .650 395.000 .650 140.000 130.000 1.900 6.690 70.000 150.000 $-.020$ 35.000 7.100

77.000 .870

.280

$$
\begin{aligned}
& 1.700 \\
& 6.700
\end{aligned}
$$

71.000

150.000

$-.020$

35.000

6.900

77.000

.870

130.000

1.700

6.820

65.000

150.000 .030

35.000

6.600

74.000

.890

446.000

.690

130.000

1.600

6.730

68.000

150.000 .070

37.000

7.100

78.000

.930

$\begin{array}{rrrr}.180 & .260 & .980 & 1.000 \\ & & .019 \\ & & 145.081 \\ & & 1.008 \\ & & .067 \\ & & -1.598 \\ & & -1.029 \\ 1.600 & 16.000 & 16.000 & 16.000 \\ & & & -73.000 \\ & & & -10.300\end{array}$

South Fence Well \#2

\section{ANALYTE}

1 Alkalinity (field)

2 Bromide

3 Chloride (Cl)

4 Fluoride (F) (Dissol

$5 \mathrm{pH}$ (field)

6 Sulfate (SO4)

7 Calcium (Ca) (Dissol

8 Iron (Fe) (Dissolved

9 Magnesium (Mg) (Diss

10 Potassium (K) (Disso

11 Sodium (Na) (Dissolv
$1992 / 01 / 00 \quad 1992 / 07 / 00$

$1993 / 04 / 00$

316.000
.680

130.000

1.800

7.080

71.000

125.000

.130

34.000

7.300

77.000
$1993 / 07 / 00$

.670

130.000

2.000

7.490

68.000

120.000

1.500

33.000

6.900

78.000
$1993 / 09 / 00$ 348.000 .700

140.000 1.900 7.140 62.000 130.000 11.000 33.000 7.000 76.000 
13 Nitrate

14 Turbidity (NTU)

15 Ionic Str (PHREEQE)

16 Carbon (PHREEQE)

17 Cat/Anion (PHREEQE)

18 SI Calcite (PHREEQE)

19 SI Gypsum (PHREEQE)

$20 \mathrm{PCO} 2$, atm (PHREEQE)

21 Silica (mg/L)

$22 \mathrm{D} / \mathrm{H}$ (ppt)

$23180 / 160$ (ppt)

South Fence Well \$2

\section{ANALYTE}

1 Alkalinity (field)

2 Bromide

3 Chloride (Cl)

4 Fluoride (F) (Dissol

$5 \mathrm{pH}$ (field)

6 Sulfate (SO4)

7 Calcium (Ca) (Dissol

8 Iron (Fe) (Dissolved

9 Magnesium (Mg) (Diss

10 Potassium (K) (Disso

11 Sodium (Na) (Dissolv

12 Nitrogen (NPN)

13 Nitrate

14 Turbidity (NTU)

15 Ionic Str (PHREEQE)

16 Carbon (PHREEQE)

17 Cat/Anion (PHREEQE)

18 SI Calcite (PHREEQE)

19 SI GYPSUM (PHREEQE)

20 PCO2, atm (PHREEQE)

21 Silica (mg/L)

$22 \mathrm{D} / \mathrm{H}$ (ppt)

$23180 / 160$ (ppt)
1993

260.000

.670

140.000

2.000

6.910

74.000

120.000

.400

33.000

6.700

74.000

.890

3.580

3.580

South Fence Well \#3P ANALYTE
1 Alkalinity (field)
2 Bromide
3 Chloride (Cl)
4 Fluoride (F) (Dissol
$5 \mathrm{pH}$ (field)
6 Sulfate (SO4)
7 Calcium (Ca) (Dissol
8 Iron (Fe) (Dissolved
9 Magnesium (Mg) (Diss
10 Potassium (K) (Disso
11 Sodium (Na) (Dissolv
12 Nitrogen (NPN)
13 Nitrate
14 Turbidity (NTU)
15 Ionic Str (PHREEQE)
16 Carbon (PHREEQE)
$17 \mathrm{Cat} /$ Anion (PHREEQE)
18 SI Calcite (PHREEQE)
19 SI Gypsum (PHREEQE)

$1993 / 1$

$$
\begin{array}{rrr}
993 / 12 / 00 & 1994 / 03 / 00 & 1994 / 06 / 00 \\
319.000 & 329.000 & 313.000 \\
.700 & .700 & .680 \\
130.000 & 140.000 & 130.000 \\
1.900 & 1.700 & 1.600 \\
6.920 & 6.850 & 7.000 \\
99.000 & 94.000 & 87.000 \\
120.000 & 120.000 & 120.000 \\
3.600 & .930 & 1.300 \\
29.000 & 28.000 & 28.000 \\
5.000 & 4.600 & 4.600 \\
92.000 & 87.000 & 86.000 \\
.900 & .960 & .900 \\
71.500 & 7.000 & 18.400 \\
& .016 & \\
& 100.440 & \\
& .976 & \\
& -.027 &
\end{array}
$$

994/06/00

$1994 / 09 / 000000 / 00 / 00$

$$
342.000
$$

.650

130.000

1.500

6.810

83.000

130.000

.650

30.000

4.800

87.000

.940

5.550

$0000 / 00 / 00$ 
20 PCO2, atm (PHREEQE)

21 silica (mg/L)

$22 \mathrm{D} / \mathrm{H}$ (ppt)

$23180 / 160$ (ppt)

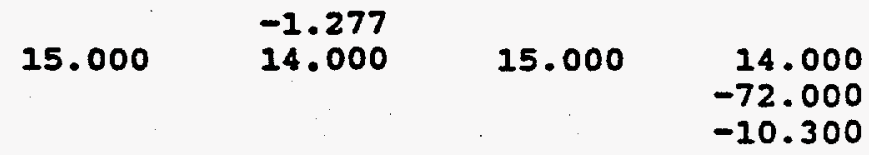

South Fence Well $\neq 3 \mathrm{~T}$

ANAIYTE

1 Alkalinity (field)

2 Bromide

3 Chloride (Cl)

4 Fluoride (F) (Dissol

5 pH (field)

6 Sulfate (SO4)

7 Calcium (Ca) (Dissol

8 Iron (Fe) (Dissolved

9 Magnesium (Mg) (Diss

10 Potassium (K) (Disso

11 Sodium (Na) (Dissolv

12 Nitrogen (NPN)

13 Nitrate

14 Turbidity (NTU)

15 IOnic Str (PHREEQE)

16 Carbon (PHREEQE)

17 Cat/Anion (PHREEQE)

18 SI Calcite (PHREEQE)

19 SI Gypsum (PHREEQE)

20 PCO2, atm (PHREEQE)

21 Silica (mg/L)

$22 \mathrm{D} / \mathrm{H}$ (ppt)

$23180 / 160$ (ppt)
$1993 / 1$

$$
\begin{array}{r}
16.000 \\
.550 \\
47.000 \\
1.600 \\
7.450 \\
2200.000 \\
450.000 \\
.020 \\
41.000 \\
5.300 \\
500.000 \\
-.050 \\
.560 \\
.062 \\
4.049 \\
1.007 \\
-.530 \\
-.049 \\
-3.238 \\
5.300
\end{array}
$$

$1994 / 03 / 00$

18.000

48.000

.400

7.770

.2600 .000

450.000

.060

40.000

5.200

510.000

.060

4.410

5.500

$1994 / 06 / 00$

$1994 / 09 / 000000 / 00 / 00$

29.000
.560

47.000

.700

8.240

2500.000

450.000

$-.020$

39.000

4.300

470.000

$-.050$

1.710

5.100

$-92.000$

$-12.400$

$1992 / 01 / 14$ 189.500

-.100
31.700

31.700

1.300

8.100

66.000

27.600

$1992 / 07 / 24$

$1993 / 04 / 00$

211.500

$-.100$

207.000

51.200

2.100

8.140

100.600

23.300

6.600

4.700

69.100

17.100

6.600

5.600

69.300

.230
32.000
1.400

8.820

46.000

37.000

1.000

10.000

4.800

69.000

3.700

28.300
$1993 / 07 / 00$ 206.000

.200

31.000

1.400

6.490

51.000

44.000

1.500

5.200

69.000

3.600
11.000
$1993 / 09 / 00$

166.000

.300

32.000

1.400

7.730

50.000

50.000

3.400

12.000

5.700

67.000

3.700

13 Nitrate

14 Turbidity (NTU)

15 Ionic Str (PHREEQE)

16 Carbon (PHREEQE)

17 Cat/Anion (PHREEQE)

18 SI Calcite (PHREEQE)

19 SI Gypsum (PHREEQE)

20 PCO2, atm (PHREEQE)

21 Silica (mg/L)

$22 \mathrm{D} / \mathrm{H}$ (ppt)

$23180 / 160$ (ppt)

\section{ANALYTE}

1 Alkalinity (field)
$1993 / 12 / 0019$ 150.000
$1994 / 03 / 00$ 177.000
$1994 / 06 / 00$ 133.000
$1994 / 09 / 000000 / 00 / 00$ 190.000 
2 Bromide

3 Chloride (Cl)

4 Fluoride (F) (Dissol

$5 \mathrm{pH}$ (field)

6 Sulfate (SO4)

7 Calcium (Ca) (Dissol

8 Iron (Fe) (Dissolved

9 Magnesium (Mg) (Diss

10 Potassium (K) (Disso

11 Sodium (Na) (Dissolv

12 Nitrogen (NPN)

13 Nitrate

14 Turbidity (NTU)

15 Ionic Str (PHREEQE)

16 Carbon (PHREEQE)

$17 \mathrm{Cat} /$ Anion (PHREEQE)

18 SI Calcite (PHREEQE)

19 SI Gypsum (PHREEQE)

$20 \mathrm{PCO} 2$, atm (PHREEQE)

21 silica (mg/I)

$22 \mathrm{D} / \mathrm{H}$ (ppt)

$23180 / 160$ (ppt)

$\begin{array}{rrrr}.250 & .220 & .190 & .200 \\ 30.000 & 30.000 & 32.000 & 23.000 \\ 1.500 & 1.400 & 1.400 & 1.300 \\ 8.150 & 7.840 & 7.860 & 8.200 \\ 48.000 & 48.000 & 50.000 & 42.000 \\ 41.000 & 41.000 & 42.000 & 45.000 \\ 1.600 & .930 & .500 & .960 \\ 11.000 & 11.000 & 10.000 & 11.000 \\ 5.300 & 6.800 & 4.500 & 4.800 \\ 61.000 & 65.000 & 55.000 & 55.000 \\ 3.700 & 3.600 & 3.700 & 3.800 \\ 3.530 & 31.900 & 13.500 & 20.800 \\ & & & .007 \\ & & & 45.294 \\ & & & 1.068 \\ & & & -2.730 \\ & & & -2.861 \\ & & & -66.000 \\ & 15.000 & & -9.800\end{array}$

Tijeras East Well

\section{ANALYTE}

1 Alkalinity (field)

2. Bromide

3 Chloride (CI)

4 Fluoride (F) (Dissol

$5 \mathrm{pH}$ (field)

6 Sulfate (SO4)

7 Calcium (Ca) (Dissol

8 Iron (Fe) (Dissolved

9 Magnesium (Mg) (Diss

10 Potassium (K) (Disso

11 Sodium (Na) (Dissolv

12 Nitrogen (NPN)

13 Nitrate

14 Turbidity (NTU)

15 Ionic Str (PHREEQE)

16 Carbon (PHREEQE)

17 Cat/Anion (PHREEQE)

18 SI Calcite (PHREEQE)

19 SI GYpsum (PHREEQE)

$20 \mathrm{PCO} 2$, atm. (PHREEQE)

21 Silica (mg/L)

$22 \mathrm{D} / \mathrm{H}$ (ppt)

$23180 / 160$ (ppt)

\section{2}

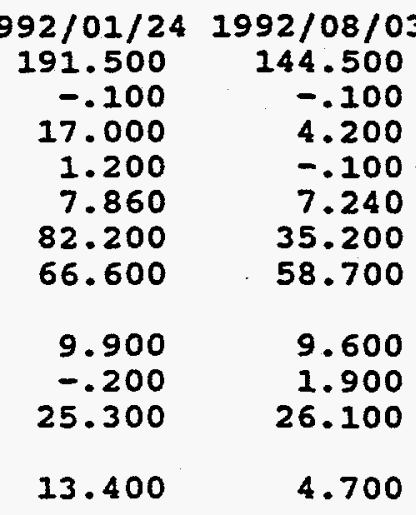

4.700

$1993 / 04 / 00$

$\begin{array}{rr}183.000 & 230.000 \\ .170 & .160 \\ 11.000 & 12.000 \\ .300 & .300 \\ 7.560 & 7.260 \\ 76.000 & 75.000 \\ 77.000 & 78.000 \\ .100 & .020 \\ 11.000 & 11.000 \\ 1.800 & 1.800 \\ 27.000 & 28.000 \\ 2.800 & 2.900\end{array}$

$1993 / 09 / 00$ 209.000 .190

13.000 .300 7.420 85.000 77.000 .020 10.000 1.600 25.000 3.100

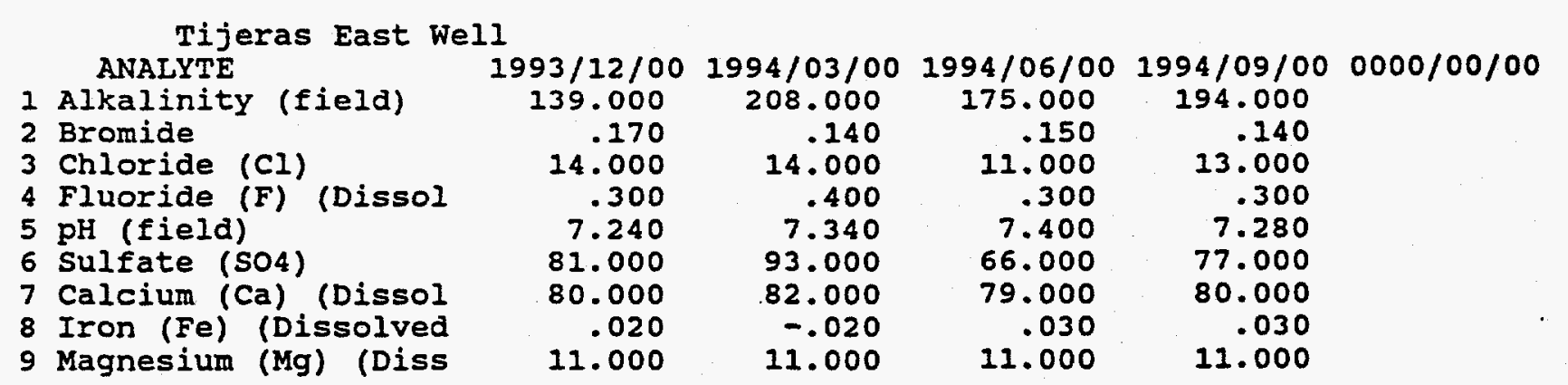



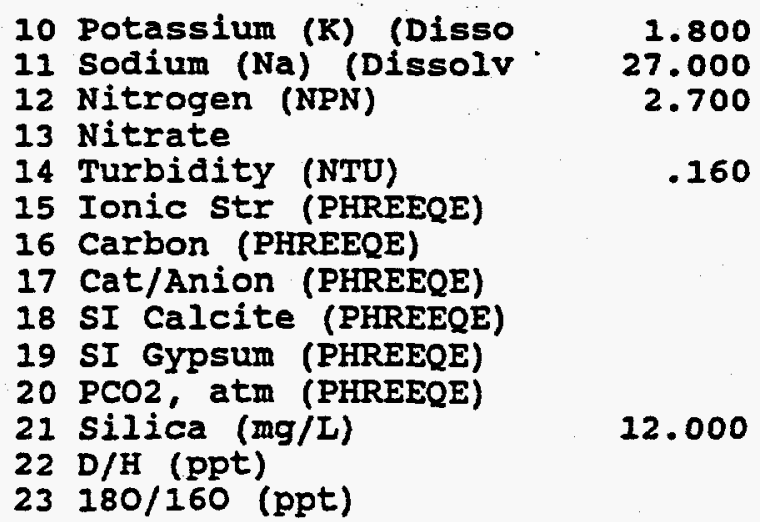

South Fence Well \#4T

ANALYTE
1 Alkalinity (field)
2 Bromide
3 Chloride (Cl)
4 Fluoride (F) (Dissol
5 pH (field)
6 Sulfate (SO4)
7 Calcium (Ca) (Dissol
8 Iron (Fe) (Dissolved
9 Magnesium (Mg) (Diss
10 Potassium (K) (Disso
11 Sodium (Na) (Dissolv
12 Nitrogen (NPN)
13 Nitrate
14 Turbidity (NTU)
15 Ionic Str (PHREEQE)
16 Carbon (PHREQR)
17 Cat/Anion (PHREEE)
18 SI CalCite (PHREEQE)
19 SI Gypsum (PHREEQE)
20 PCO2, atm (PHREEQE)
21 Silica (mg/L)
22 D/H. (ppt)
23 180/160 (Ppt)

$1995 / 03 / 29$

110.000

1.000

180.000

3.000

7.570

1900.000

57.000

.050

3.400

2.500

1200.000

0.620

1.650

0.067

27.564

1.196

$-0.470$

$-0.956$

$-2.513$

4.800

PL-3 Well

ANAIYTE

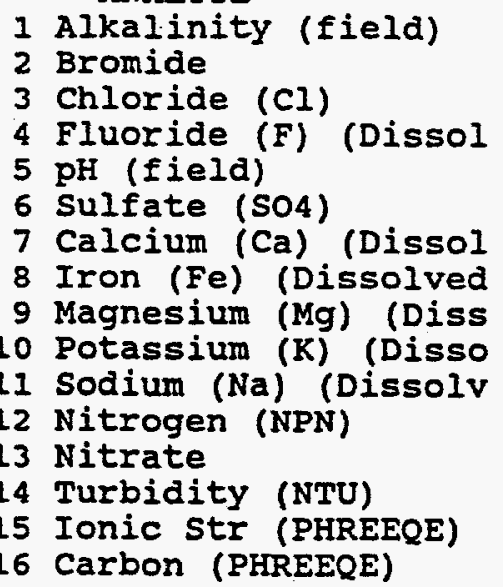
$1995 / 03 / 30$
160.000
0.200
20.000
0.300
7.160
70.000
59.000
.100
12.000
4.700
27.000
5.000
0.890
0.007
43.677

$\begin{array}{rrr}1.600 & 1.900 & 1.700 \\ 27.000 & 29.000 & 27.000 \\ 2.600 & 2.800 & 2.900 \\ & & \\ 1.200 & .630 & .890 \\ .009 & & \\ 54.283 & & \\ .955 & & \\ .154 & & \\ -1.564 & & \\ -1.954 & & \\ 11.000 & 11.000 & 11.000 \\ & & -78.000 \\ & & -10.900\end{array}$




$\begin{array}{ll}17 \text { Cat/Anion (PHREEQE) } & 1.002 \\ 18 \text { SI Calcite (PHREEQE) } & -0.255 \\ 19 \text { SI Gypsum (PHREEQE) } & -1.783 \\ 20 \text { PCO2, atm (PHREEQE) } & -1.882 \\ 21 \text { Silica (mg/L) } & 16.000 \\ 22 \text { D/H (ppt) } & \\ 23.180 / 160 \text { (ppt) } & \end{array}$

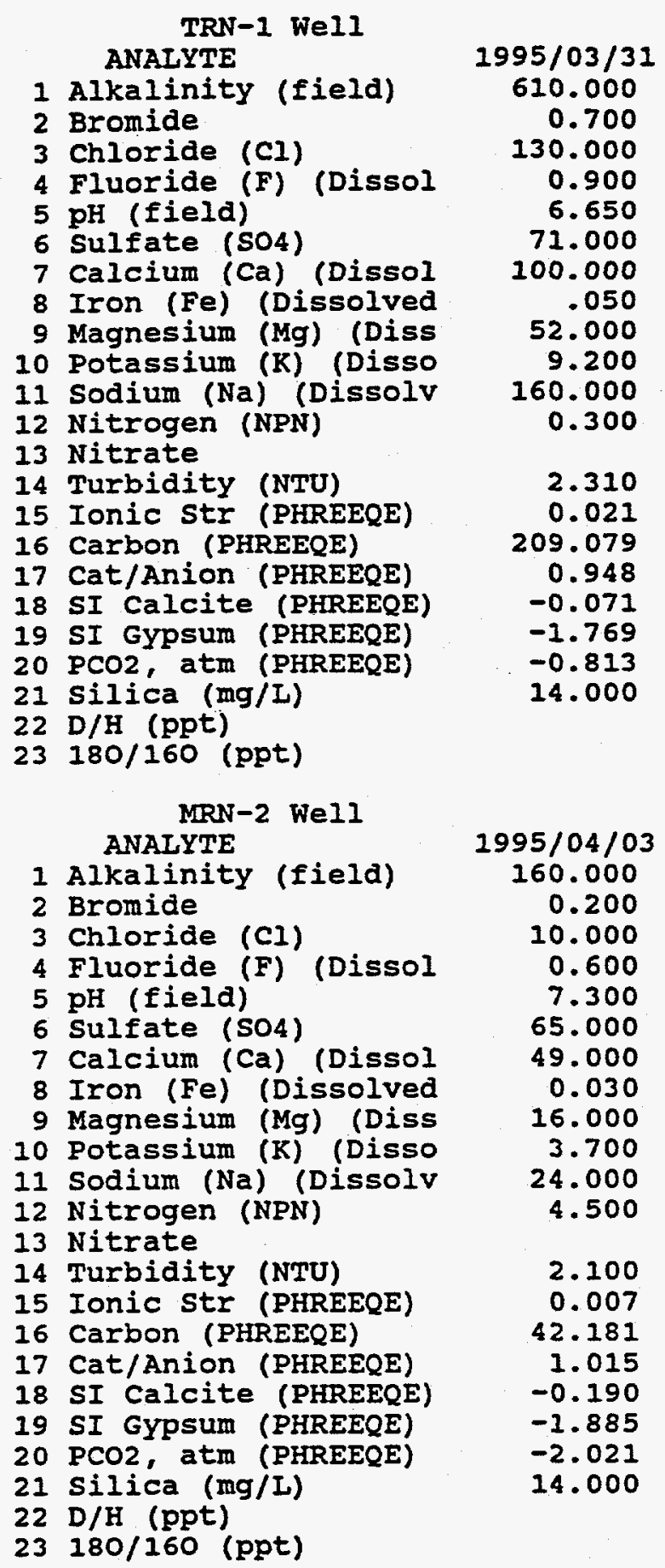




$\begin{array}{lr}\text { ANALYTE } & 1995 / 04 / 04 \\ 1 \text { Alkalinity (field) } & 110.000 \\ 2 \text { Bromide } & 1.000 \\ 3 \text { Chloride (CI) (Dissol } & 72.000 \\ 4 \text { Fluoride (F) (Did } & 0.200 \\ 5 \text { pH (field) } & 7.300 \\ 6 \text { Sulfate (SO4) } & 61.000 \\ 7 \text { Calcium (Ca) (Dissol } & 80.000 \\ 8 \text { Iron (Fe) (Dissolved } & -0.020 \\ 9 \text { Magnesium (Mg) (Diss } & 13.000 \\ 10 \text { Potassium (K) (Disso } & 1.800 \\ 11 \text { Sodium (Na) (Dissolv } & 23.000 \\ 12 \text { Nitrogen (NPN) } & 6.000 \\ 13 \text { Nitrate } & \\ 14 \text { Turbidity (NTU) } & 0.340 \\ 15 \text { Ionic Str (PHREEQE) } & 0.008 \\ 16 \text { Carbon (PHREEQE) } & 28.949 \\ 17 \text { Cat/Anion (PHREEQE) } & 1.117 \\ 18 \text { SI Calcite (PHREEQE) } & -0.151 \\ 19 \text { SI Gypsum (PHREEQE) } & -1.737 \\ 20 \text { PCo2, atm (PHREEQE) } & -2.190 \\ 21 \text { Silica (mg/L) } & 11.000 \\ 22 \text { D/H (ppt) } & \\ 23 \text { l80/160 (Ppt) } & \end{array}$

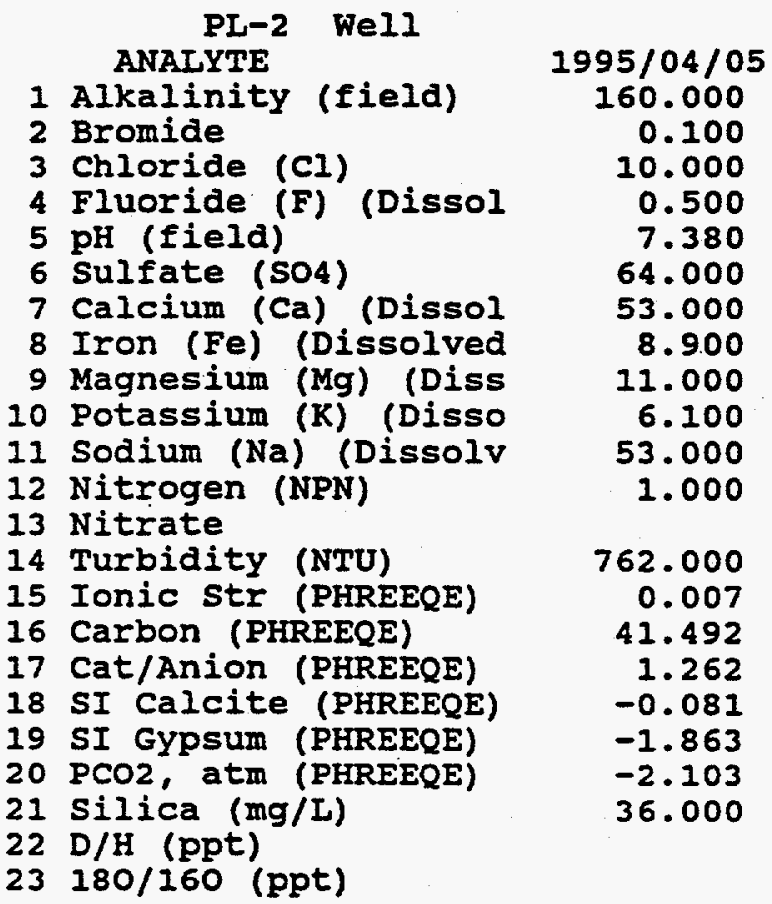

\begin{tabular}{lr}
\multicolumn{3}{c}{ MRN-1 Well } \\
ANALYTE & $1995 / 04 / 11$ \\
1 Alkalinity (field) & 320.000 \\
2 Bromide & 0.200 \\
3 Chloride (Cl) & 86.000 \\
4 Fluoride (F) (Dissol & 1.000 \\
5 pH (field) & 7.040 \\
6 Sulfate (SO4) & 130.000
\end{tabular}


7 Calcium (Ca) (Dissol
8 Iron (Fe) (Dissolved

150.000

72.000

9 Magnesium (Mg) (Diss

48.000

10 Potassium (K) (Disso

16.000

11 Sodium (Na) (Dissolv

12 Nitrogen (NPN)

180.000

4.000

13 Nitrate

14 Turbidity (NTU)

$+1000.000$

16 Carbon (PHREEQE)

17 Cat/Anion (PHREEQE)

18 SI Calcite (PHREEQE)

19 SI Gypsum (PHREEQE)

$20 \mathrm{PCO} 2$, atm (PHREEQE)

21 Silica (mg/L)

210.000

$22 \mathrm{D} / \mathrm{H}$ (ppt)

$23180 / 160$ (ppt) 


\section{Appendix B}

\section{Histograms}

All samples included in sand.dat (Appendix A) were used. Four sets of histograms are included:

- all wells, linear scale

- $\quad$ all wells, logarithmic scale

- Tsf wells only, linear scale

- Tsf wells only, logarithmic scale 
1

I

I

I

I

I

I

I

I

】

】

】

I

】

I

I

I

】

I 

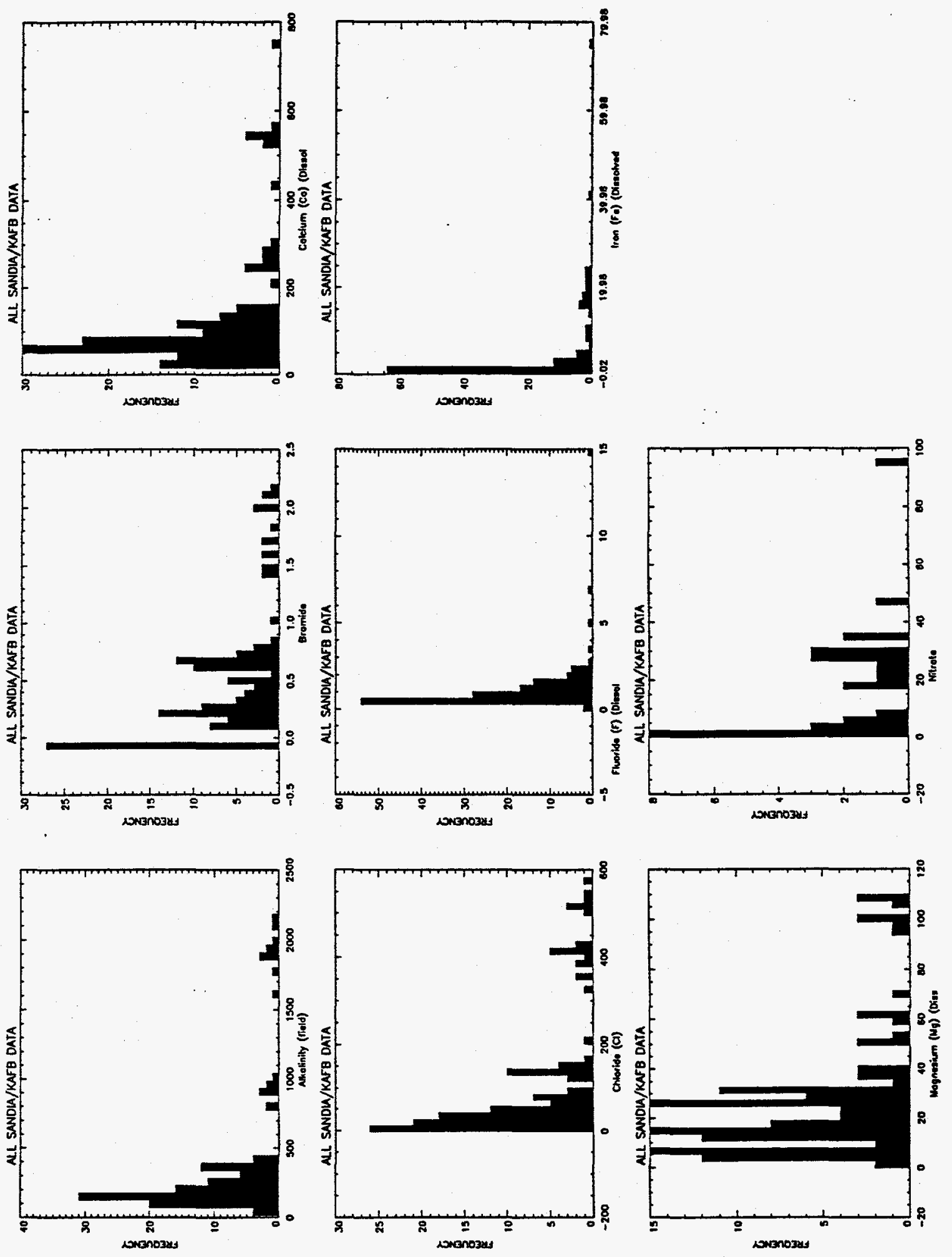

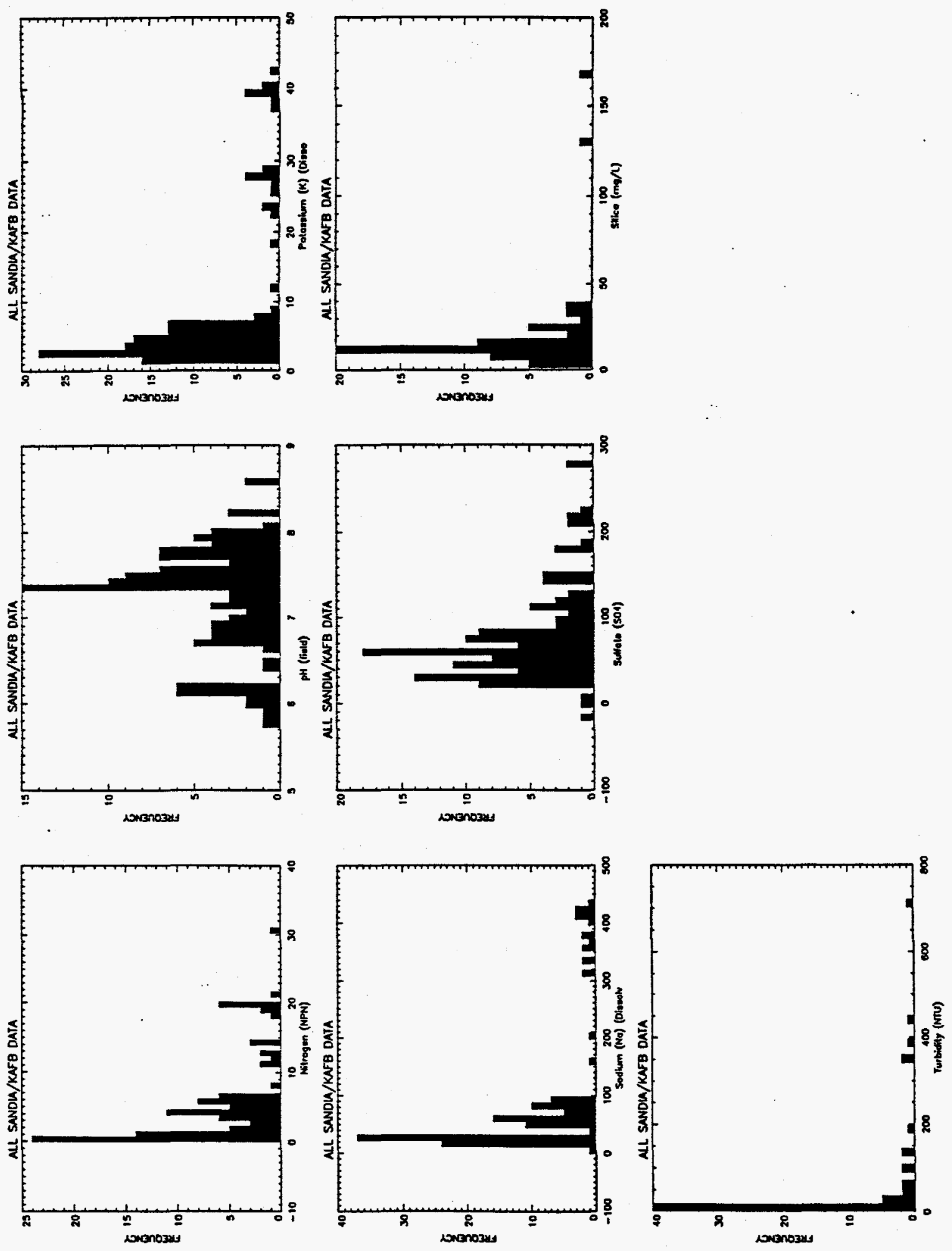

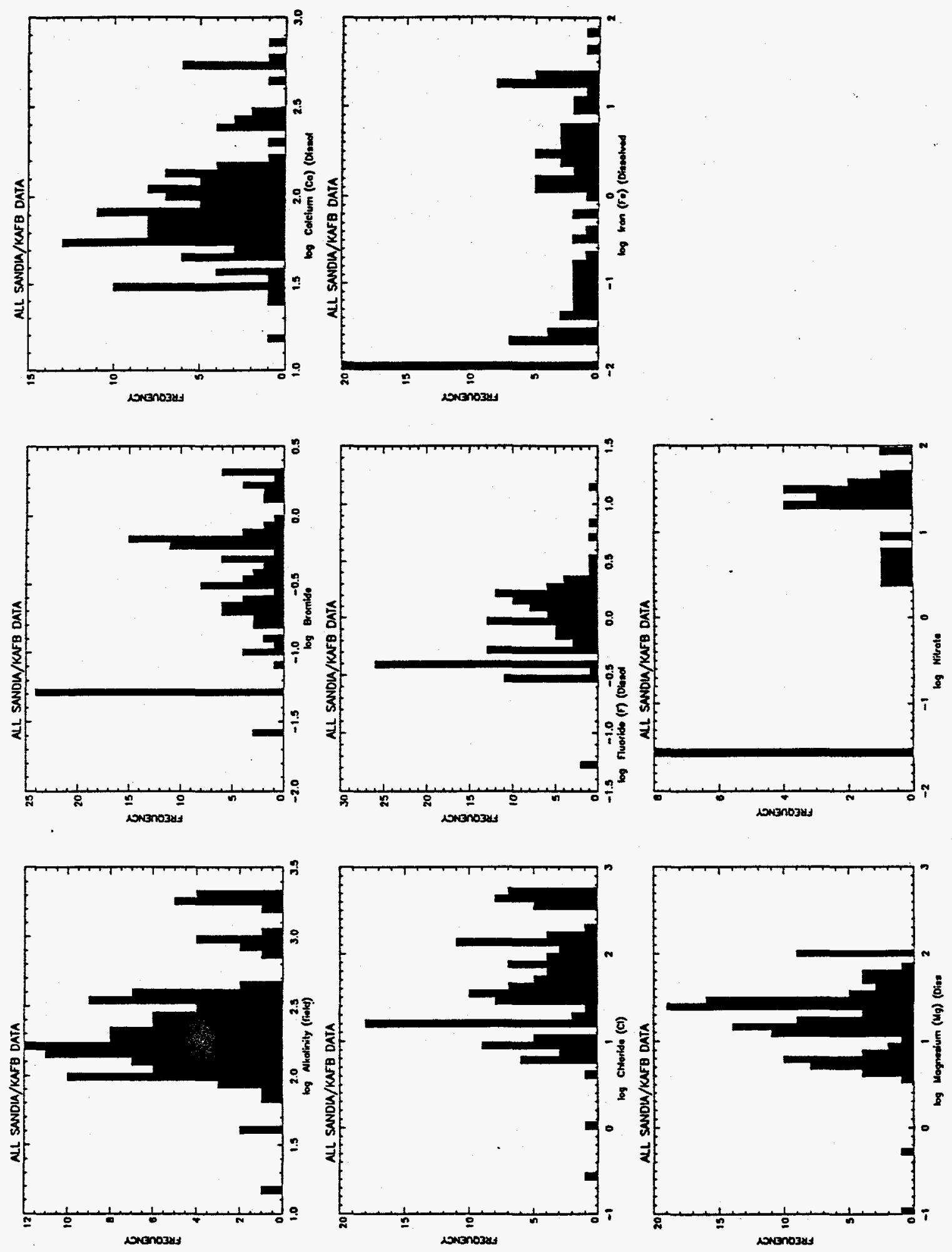

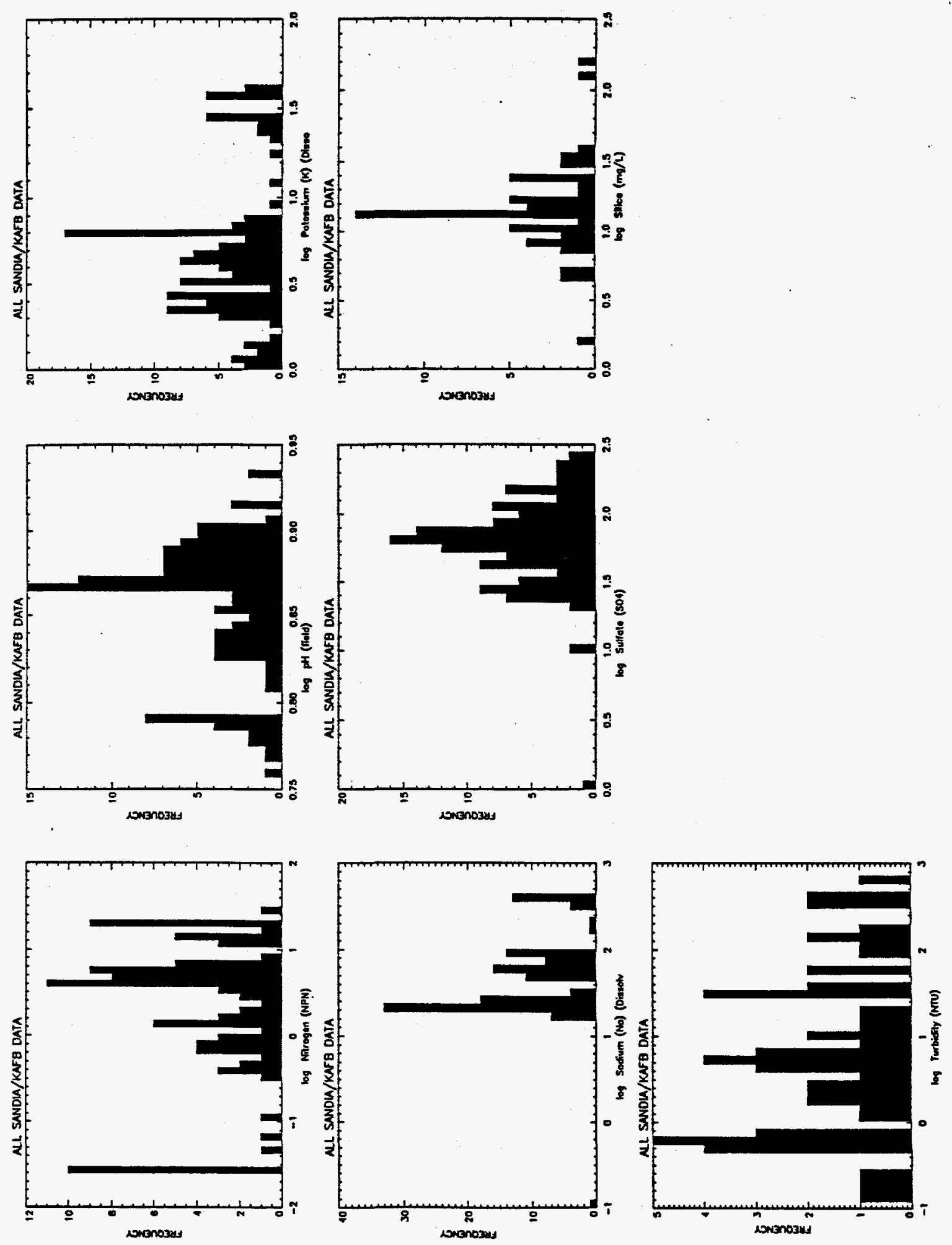

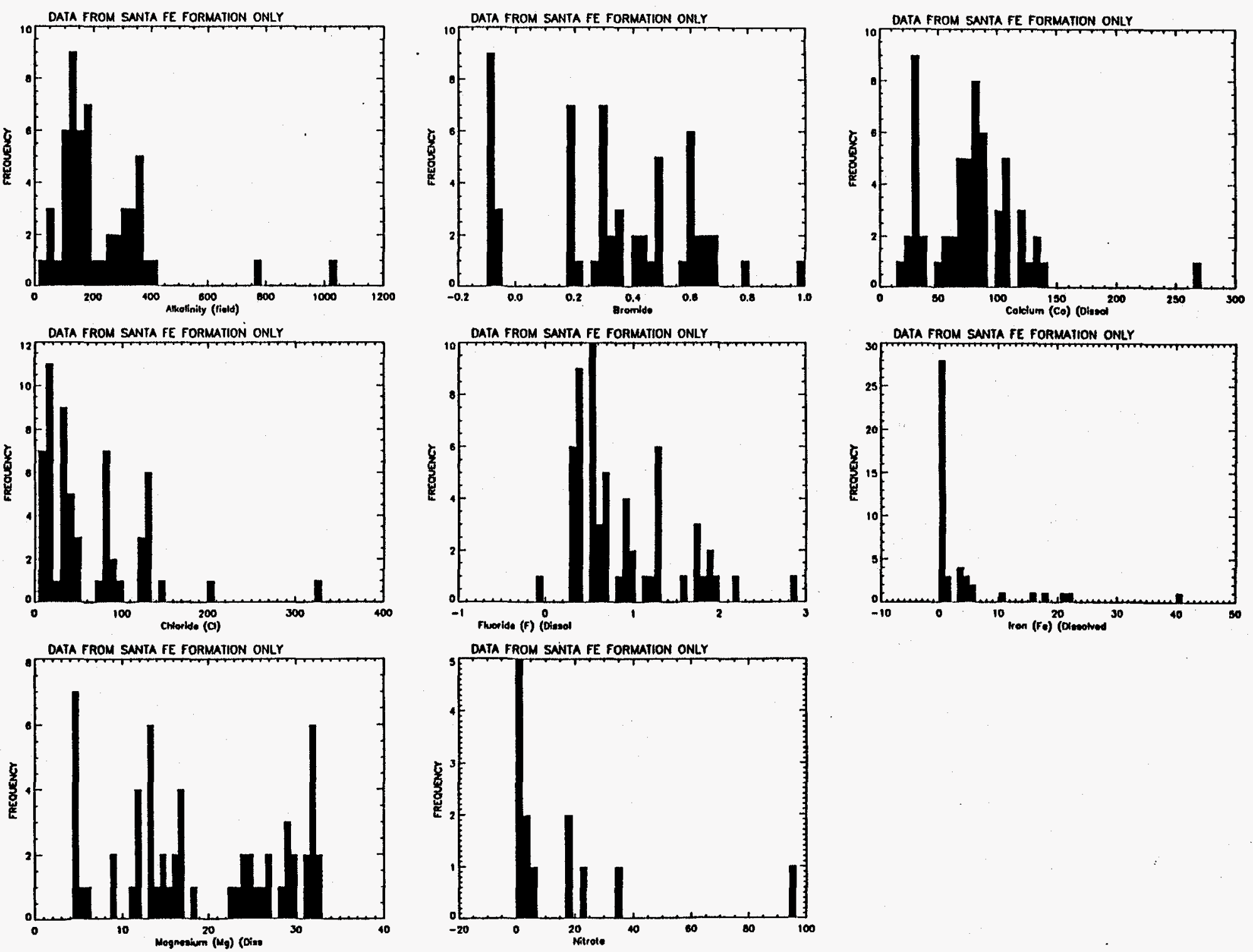

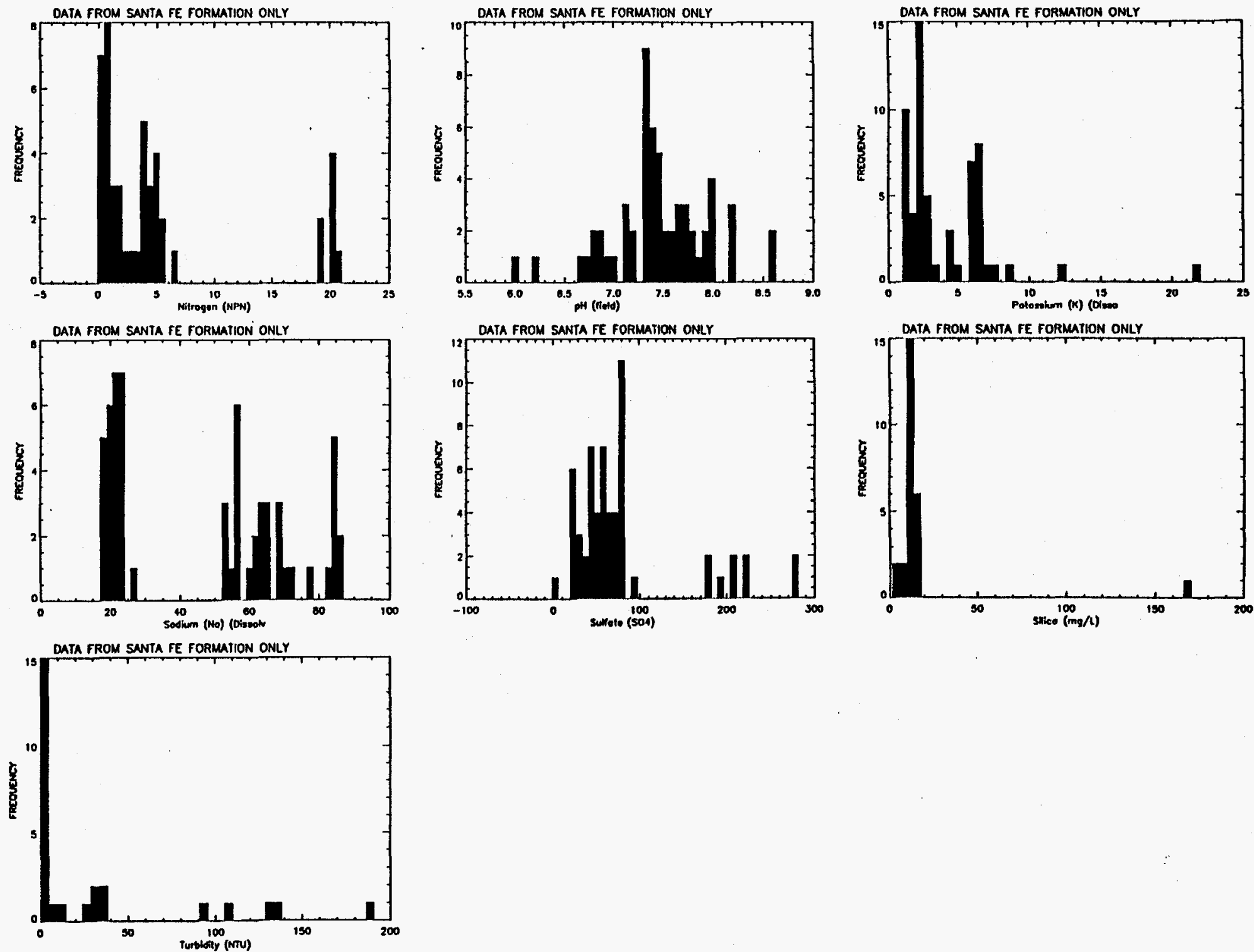

$$
\text { . }
$$



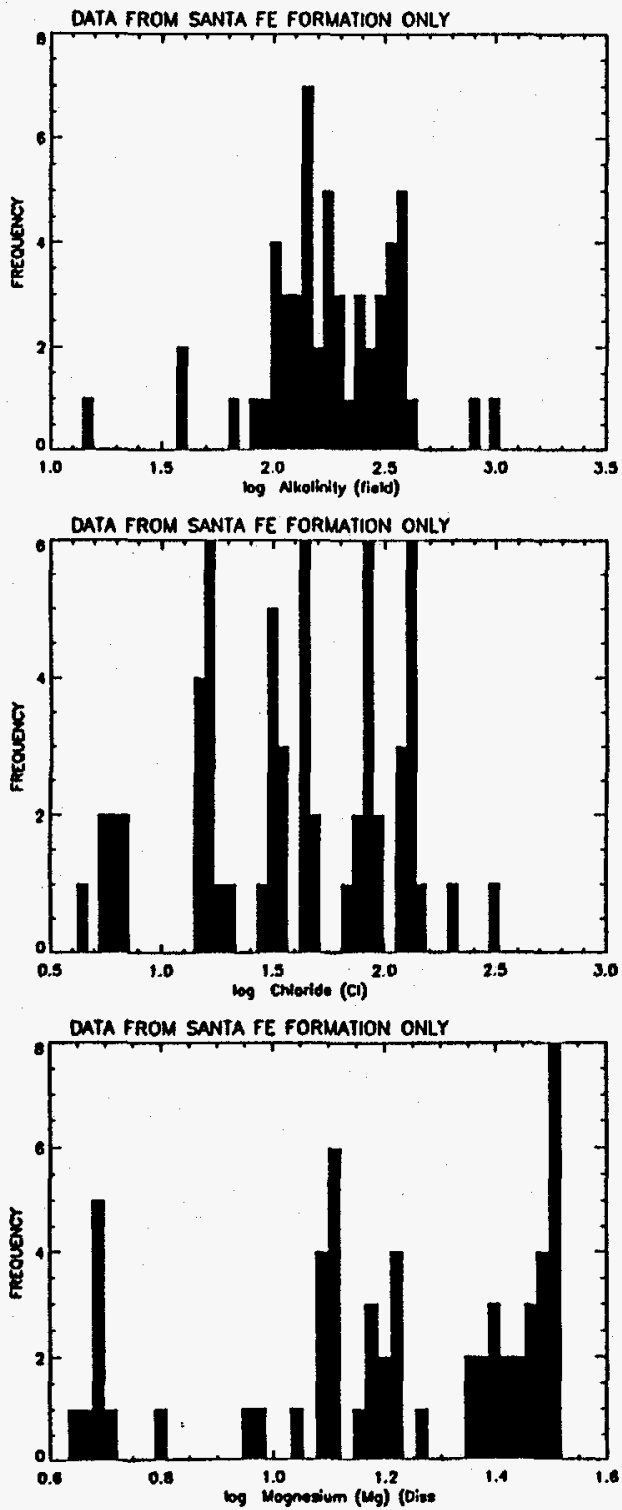
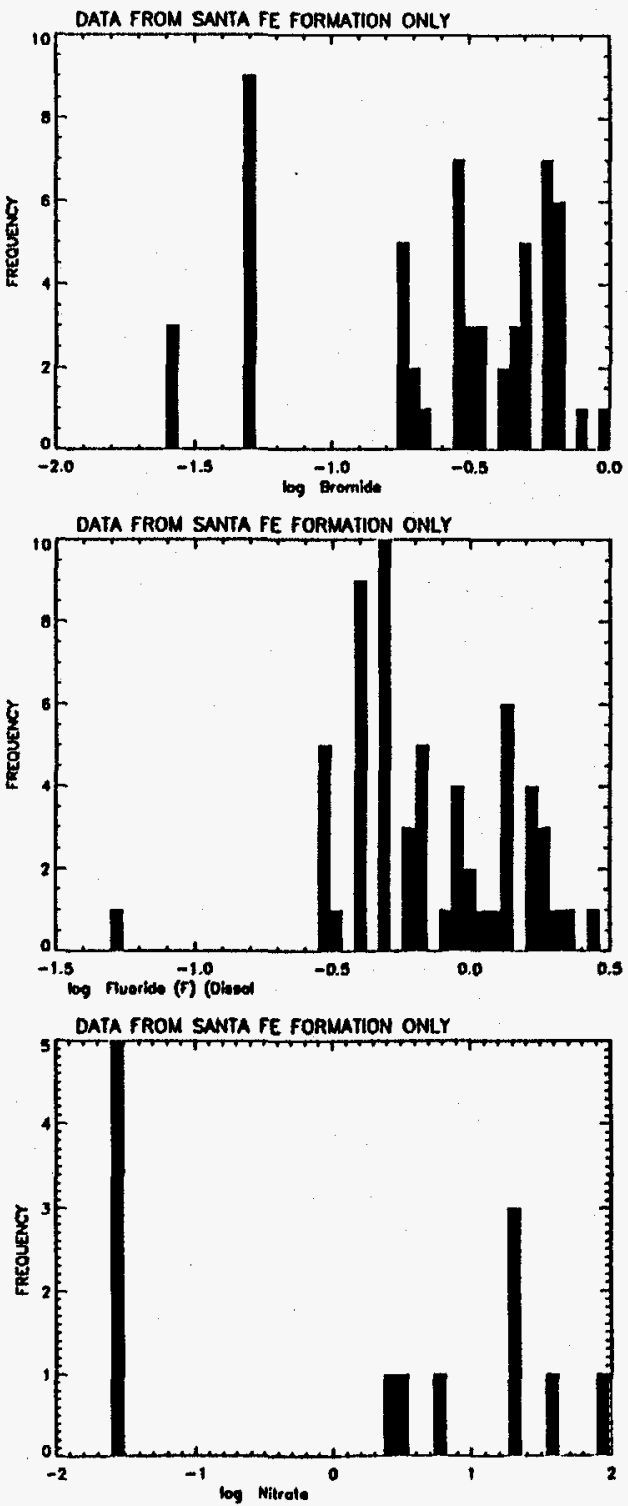
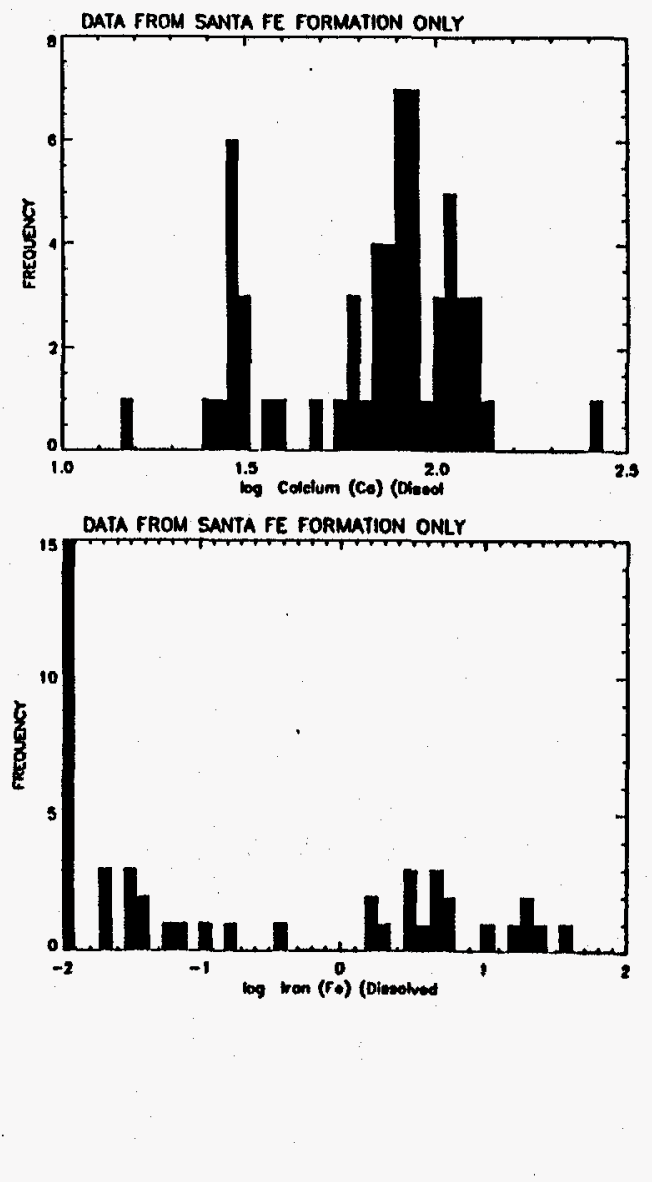

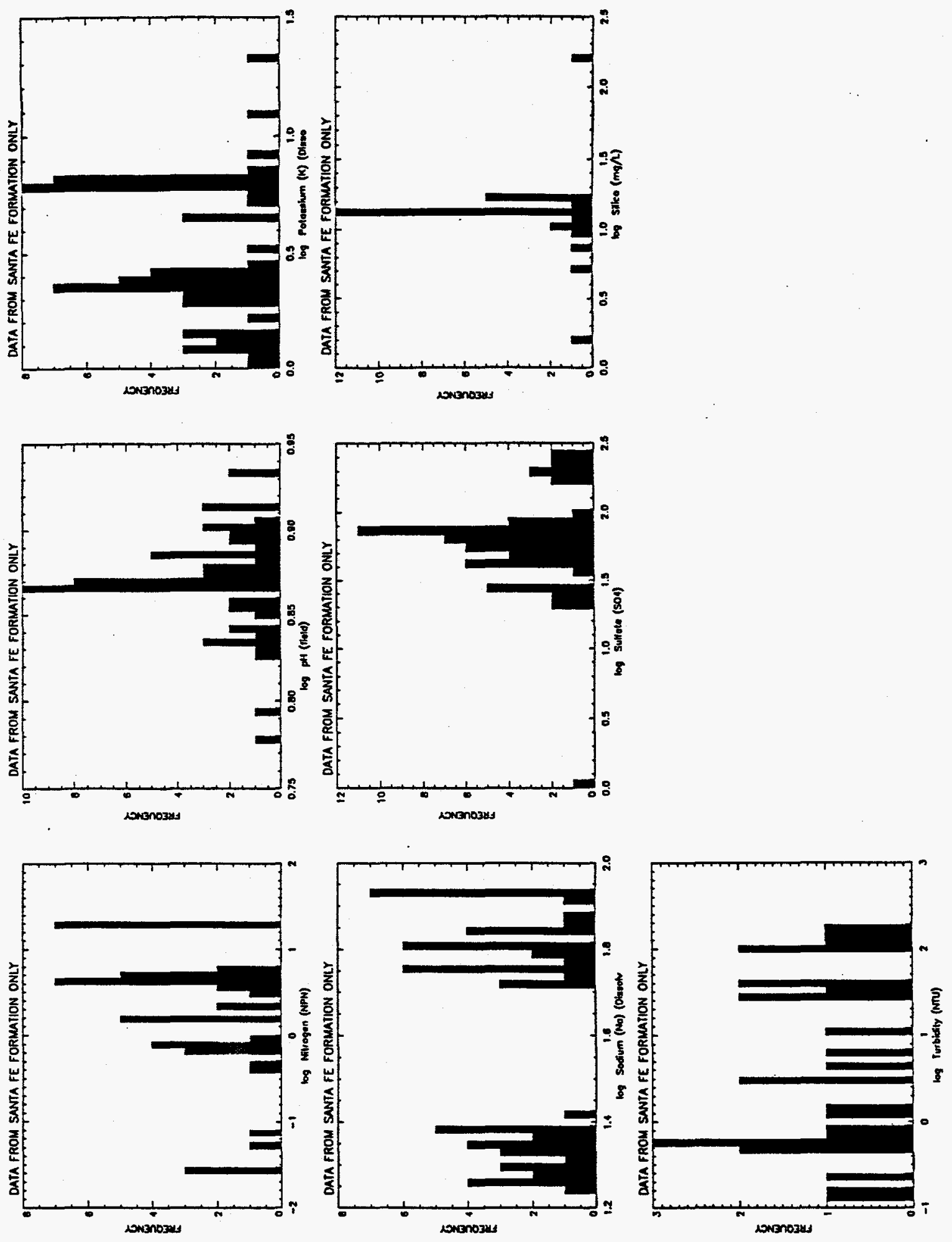


\section{Appendix C}

\section{Chemical Spot Plots for the Most Representative Data for All Wells and Springs (in alphabetical order)}




\section{Appendix D}

Chemical Spot Plots for the Most Representative Data for Wells Screened in the Santa Fe Group (in alphabetical order) 


\section{Appendix E}

\section{Summary of Mineralogy as Compiled from Well Logs and Thin Section Descriptions}


】

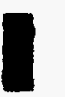

I

I

I

I

I

I

I

I

I

I

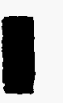

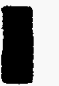

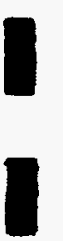

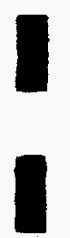

I 
MINERALOGY FROM THE

LITHOLOGIC LOGS

\section{BURN SITE WELLL Bedrock \\ clay \\ mica schist \\ quartz \\ granite \\ CWL-BW2 \\ Santa Fe Fm \\ clay \\ gravel \\ EOD HILL WELLL \\ Madera IS \\ carbonate}

GOLF COURSE SOUTH

WELL

Santa Fe Fm

caliche (near surface)

clay

GREYSTONE WELL

Qal

no $\log$

KAEB-10 WELL.

Santa Fe Fm

clay

limestone@1025

LEDM-01 WELL

Santa Fe Fm

no $\log$

LEMDM-02 WEILL

Santa Fe Fm

no log

MVMW-I WELLL

Santa Fe Em

clay

MWL-BW1 WELL Santa Fe Em limestone clasts

caliche (near surface)

quartz

calcareous

NWTA-3 WELL

Santa Fe Em

caliche (to $200 \mathrm{ft}$ )

calcareous

limestone

clay

granite clasts

oxidized biotite

muscovite

organic blebs? (410 ft)

agate

SCHOOLHOUSE WETL.

Qal

no log

SOUTH FENCE WEIL\#1

Santa Fe Group

clay

limestone

granite

caliche

quartz

feldspar

greenstone

reacts with $\mathrm{HCl}$

arkose

pinkish gray (oxidized?)

grayish green (reduced?)

chert

volcanic ash

obsidian

mafic minerals

black organics

quartzite

dolomitc limestone

decomposed tuff?

SOUTHEENCE WELL \#2

Santa Fe Fm

caliche

reaction with $\mathrm{HCl}$

quartz

granite

limestone

clay

quartzite

arkose

feldspar

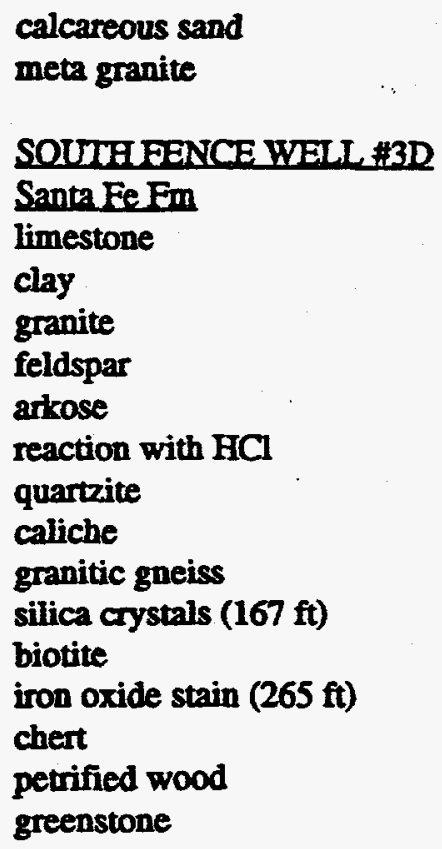

Eault Zone (520-680 ft)

black organic

slickensides

clay stone

greenish clay streaks

Mn stain

drusy calcite

reaction with $\mathrm{HCl}$

clay

calcite spar

carboniferous shale

limestone

coal?

Fe stain

$\mathrm{CaCO} 3$

gypsum? in hairline fractures (583 ft)

gypsum (starts at 583ft)

no reaction with $\mathrm{HCl}(583 \mathrm{ft}$ ) 
Lower Tertiary (680-890 ft)

mudstone

detrital limestone

reaction with $\mathrm{HCl}$

calcite in fractures

arkosic

quartz

few marcasite/pyrite spots (705

ft)

greenish gray

Yeso Fm (890-1151 TD)

abundant gypsum

$\mathrm{CaCO} 3$

reaction with $\mathrm{HCl}$

quartz

mafics(?)

limestone

chert

selenite gypsum

satin spar gypsum

brownish to greenish-gray

(reduced?)

anhydrite

dolomitic(?) anhydrite

SWTA-3 WELL.

Santa Fe Fm

quartz

granite

carboniferous nodules ( $200 \mathrm{ft})$

volcanic clasts

\section{TIJERAS EAST WELL}

Santa Fe Em

arkosic

sand/gravel (no mineralogy

given) 